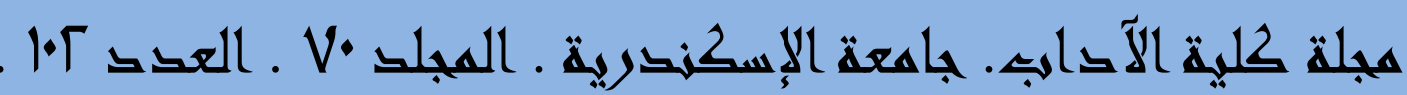

الطقل والتنشئة الاجتماعية على المواطنة فى الحياة اليومية خلال الألفية الجديدة: تحليل سوسيولوجى لنماذج من الحقوق والمعوقات

\author{
الأستاذ الدكتور \\ هانى خميس أحمد عبده الأنياذ

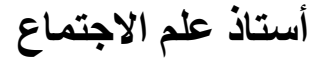 \\ كلية الآداب - جامعة الإسكندرية
}

$r \cdot r \cdot$ 


\section{الطقل والتنشئة الاجتماعية على المواطنة فى الحياة اليومية خلال الألفية الجديدة: تحليل سوسيولوجى لنماذج من الحقوق والمعوقات}

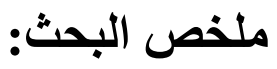

يشغل مفهوم المو اطنة اهتمام الباحثين و المشتغلين فى مجال العلم الاجتماعى و الذى الذى

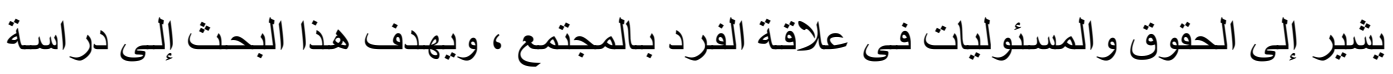

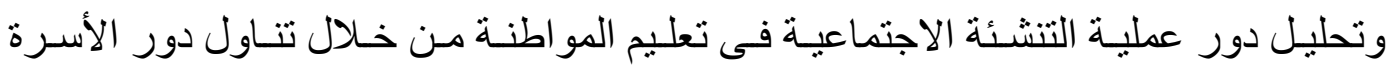

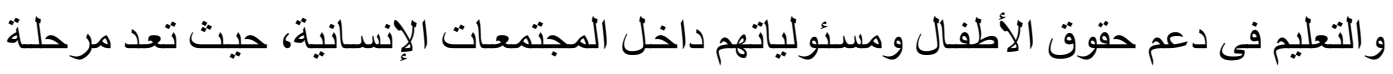

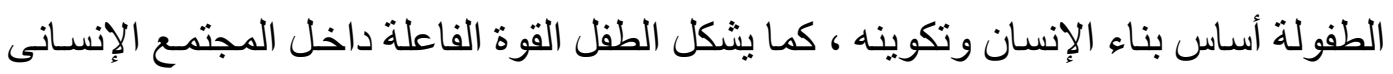
لصناعة المستقبل.

الكلمات المفتاحية:

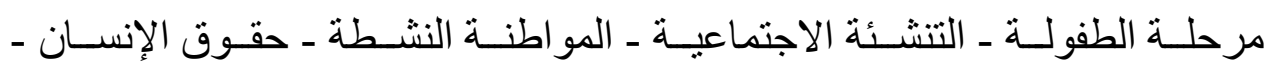

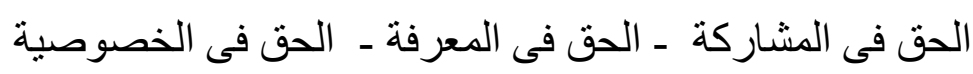




\section{تمهيد لموضوع البحث:}

لقد أصبح مفهوم "المو اطنة" Citizenship خلال حقبة التسعينيات من القرن العشرين يشغل اهتمام الباحثين و المشتغلين بمجال العلم الاجتماعى، ومن بين العو امل المتعددة التى التى

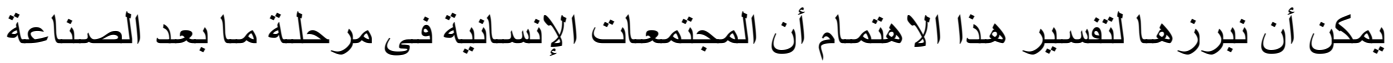

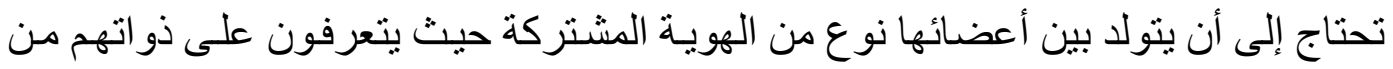

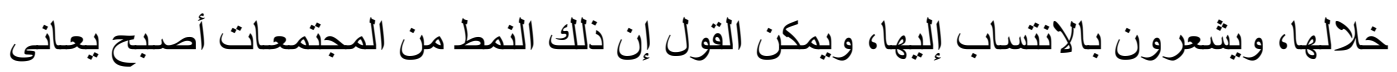
بوضوح من نقص فى الانتماء من جانب المو اطنين، ومن دون هذا الانتماء قد يصبح من

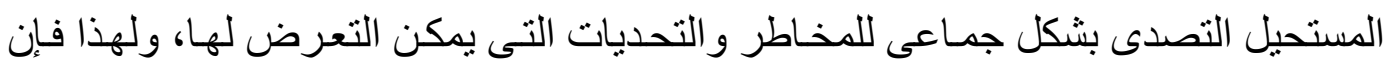

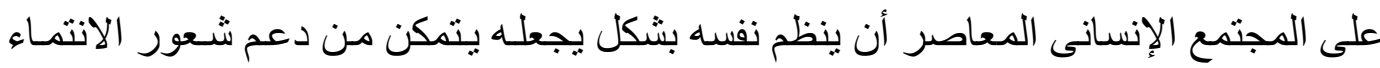

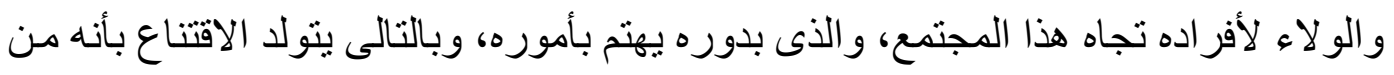

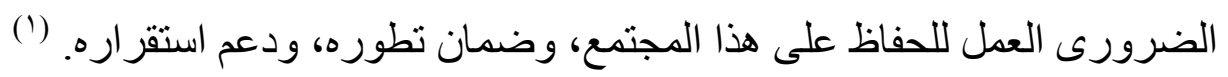

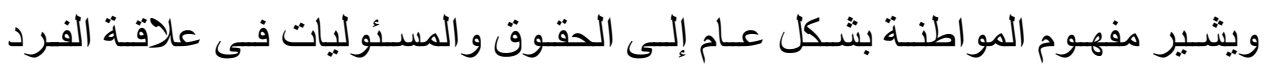
بالمجتمع/ الدولة، ويمكن القول إن المواطنة ليست فقط مسئولية الدولة تجاه الأفر اد، بل أيضاً

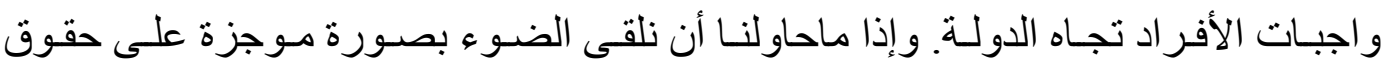

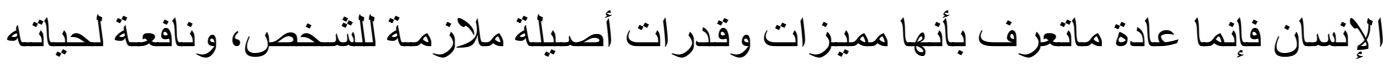

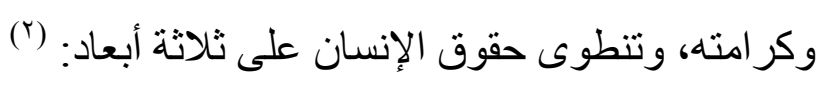

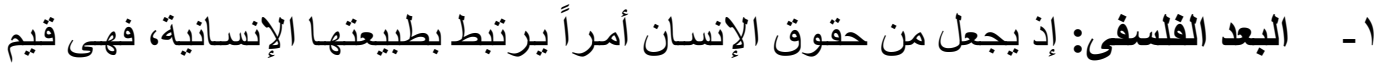

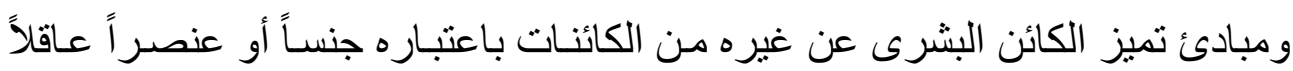

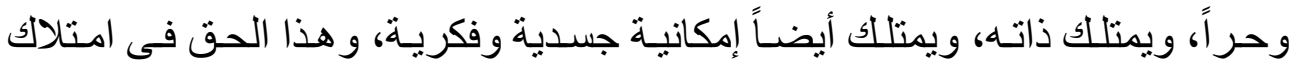
الذات و الإمكانيات الجسدية و الفكرية شرط ضرورى لتمبيزه ككائن بشرى. r- - البعد التاريخى: إن حقوق الإنسـان، وقيمها، ومبادئها إنتاج إنسانى عـالمى مشترك

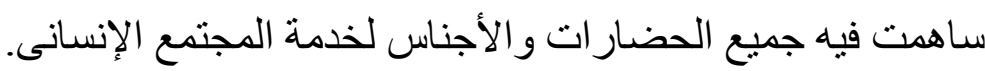

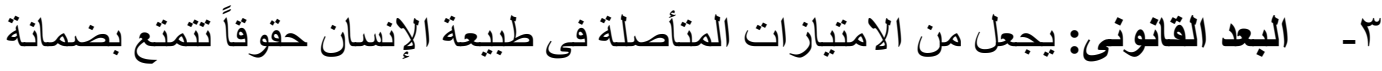

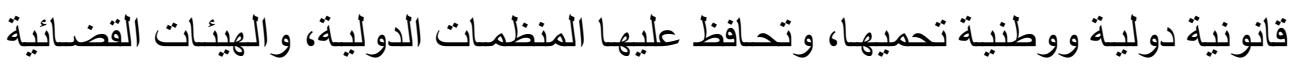

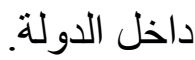

ويمكن القول إن حقوق الإنسان شاملة، وليست قاصرة على فئة معينة من الأفر اد، ولا على بقعة واحدة من العـالم، و لا على زمـان محدد، و إنما حقوق موجودة وملازمـة للإنسـان

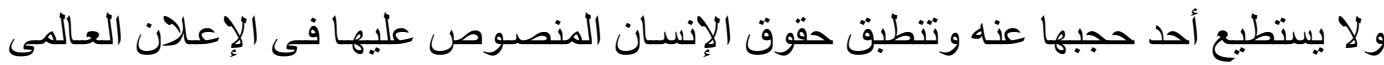


لحقوق الإنسان على جميع البشر بغض النظر عن أعمار هم، وبهذه الصفة فإن الأطفـال

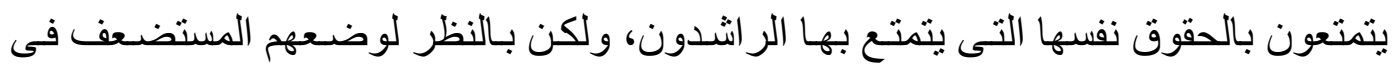

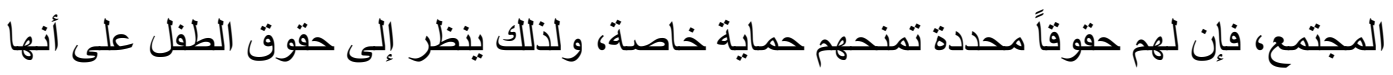

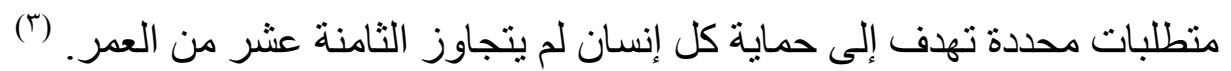
وفى ضوء ماسبق ييرز موضوع البحث فى تناول دور التنشئة الاجتماعية فى تعليم

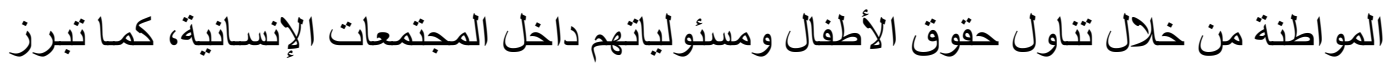

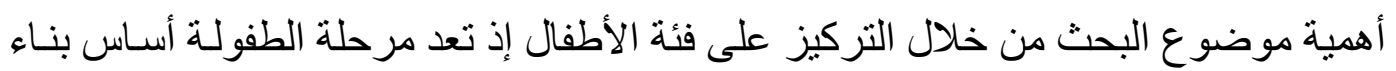

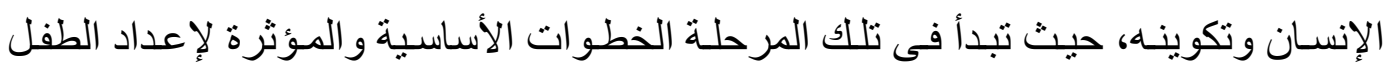

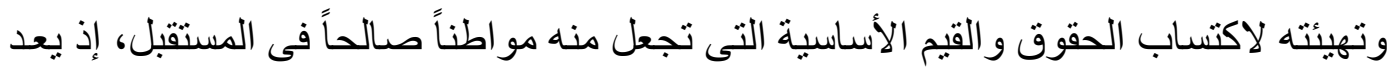

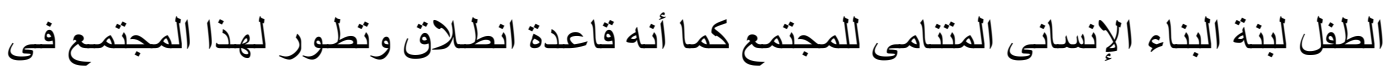

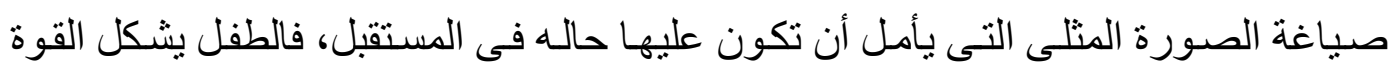

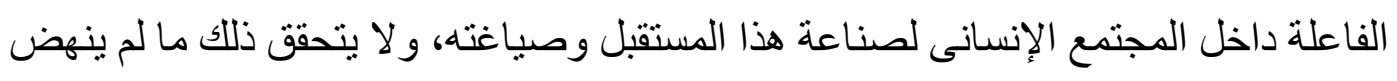
هذا المجتمع وينطلق بداية من الطفل نفسه، وبالاعتماد عليه، وفى محيط قدر اتها.

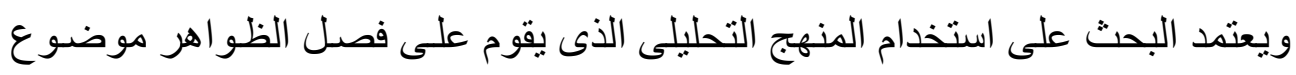

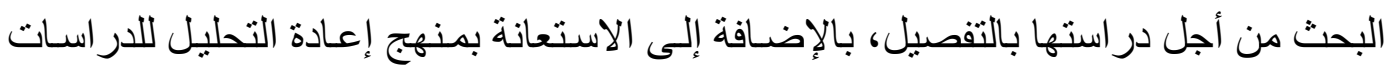

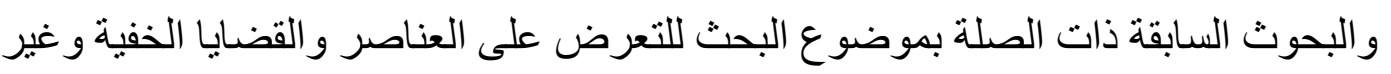

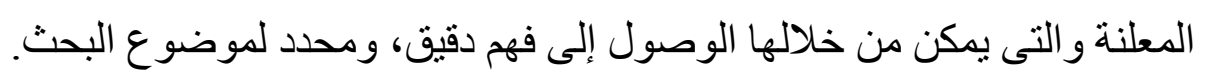
كما سوف سيعتمد الباحث على تقسيم عناصر بحثه إلى مبحثين، أمسا المبحث الأول فيتضمن الإطار النظرى للبحث و الذى سوف يتناول مرحلة الطفولة بين الحماية و الاستقلال

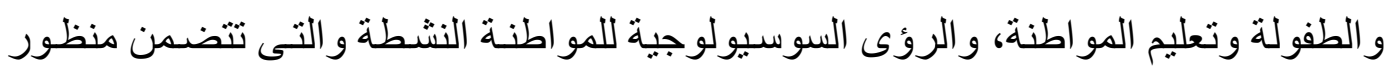

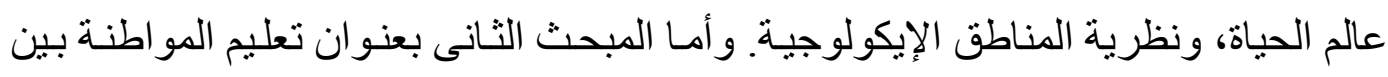

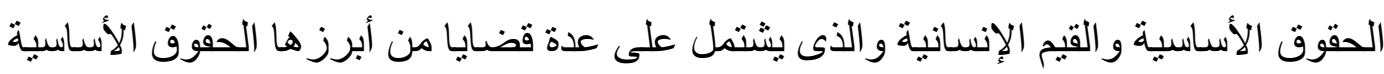

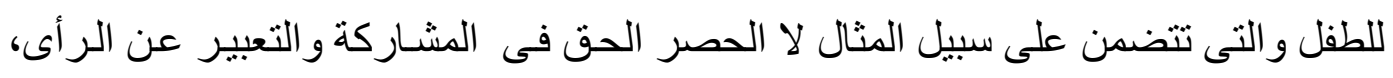

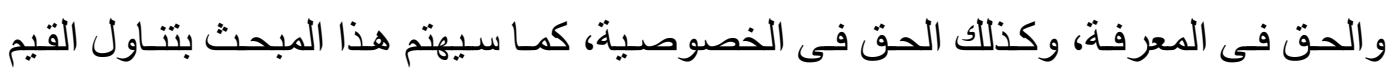

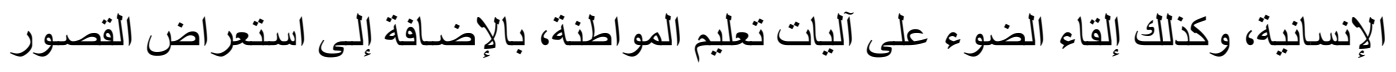

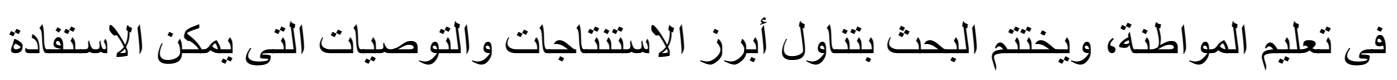

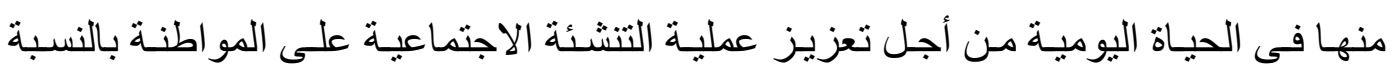
للأطفال فى مجتمعاتنا العربية. 


\section{المبحث الأول: الإطار النظرى للبحث}

يتضـمن الإطـار النظـرى للبحث تتـاول مرحلـة الطفولـة بـين الحمايـة والاستقلال،

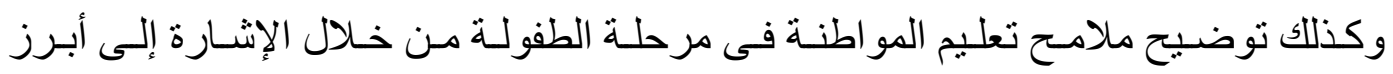

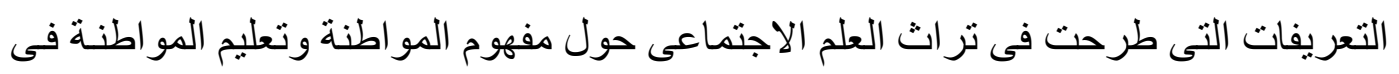

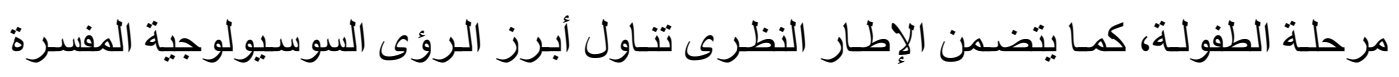

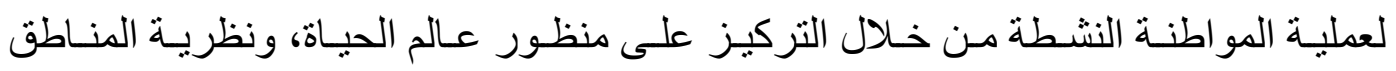

الإيكولوجية.

\section{أولاً: مرحلة الطقولة بين الحماية والاستقلال:}

تعد مرحلة الطفولة بمثابة واقع متناقض، فمن ناحية هناك تأكيد على أهمية إحاطة

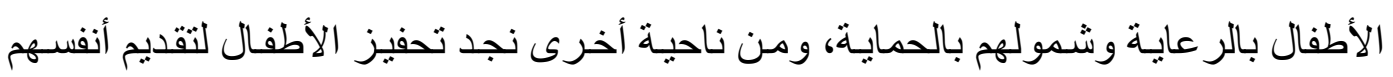

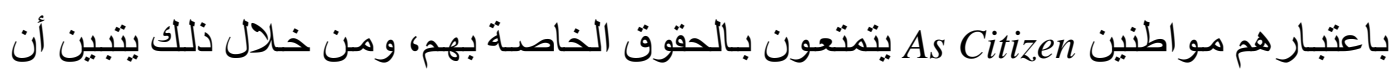

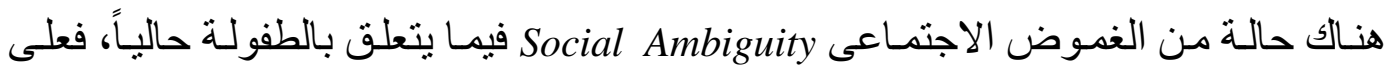

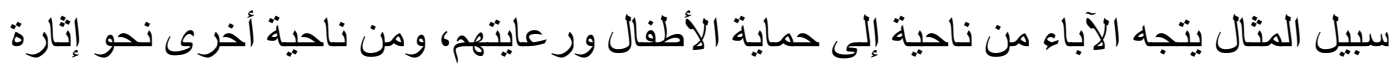

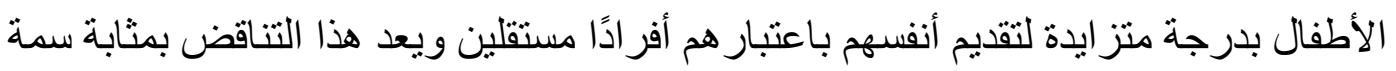

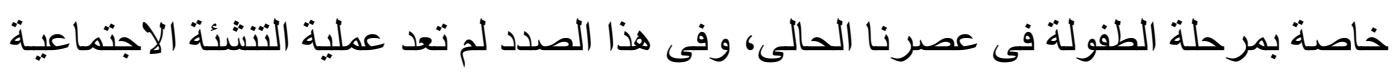

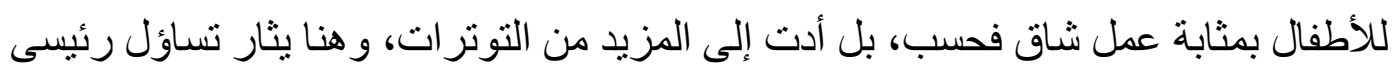

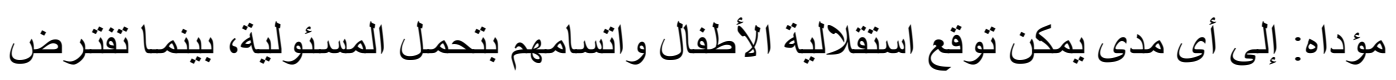

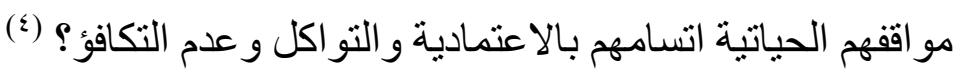

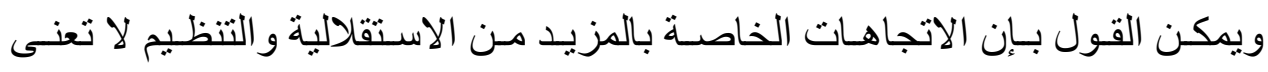

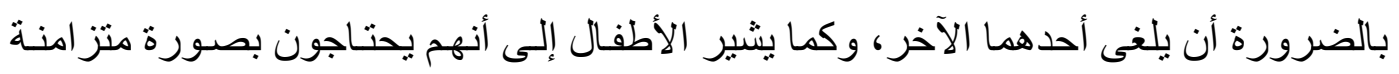

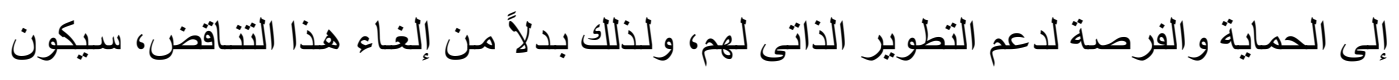

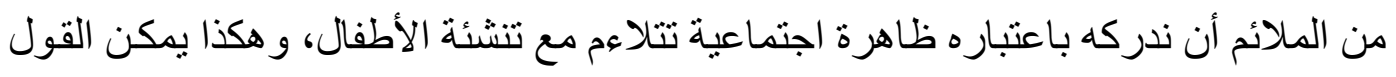

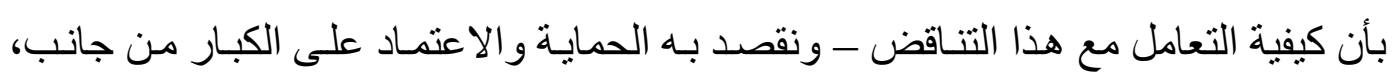

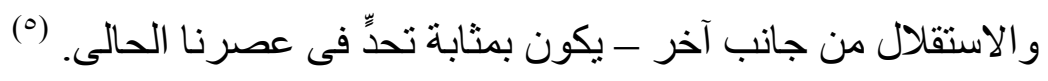

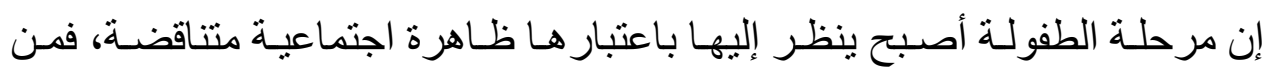

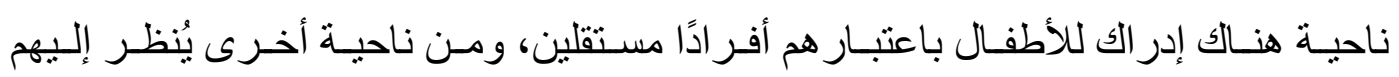
باعتبار هم أفر ادًا فى حاجة إلى الحماية و المساندة، وعلى الر غم من تنـاقض ظـاهرة الطفولنة 
فإنه قد أصبح من المكن إدر الك الأطفال اليوم باعتبار هم دواطنين يتسمون بالفاعلية، كما أن

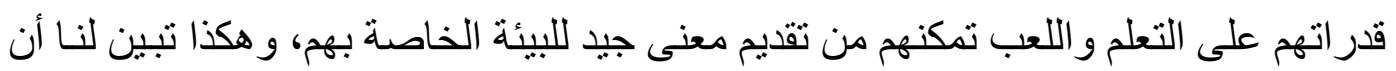

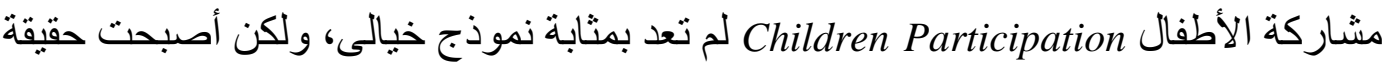

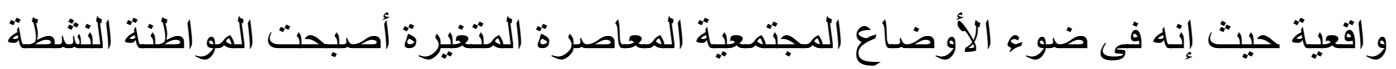
بctive Citizenship و والواجبات.(1)

فعلى سبيل المثال يقوم الكبار فى الغرب بتشجيع الأطفال بإعداد الحياة الخاصـة بهم فى ظل المخاطر و التحديات المجتمعية المعاصرة، ومن ثم يبدأ الأطفال فى تقديم أنفسهر

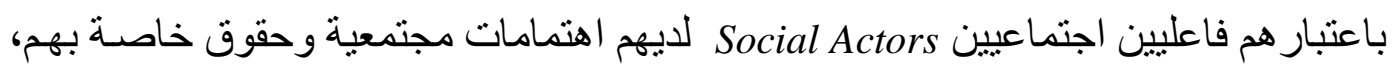

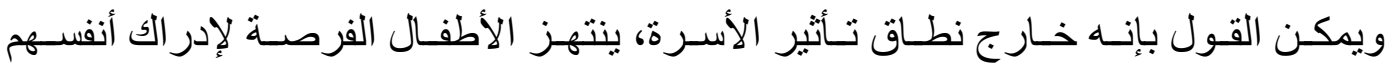

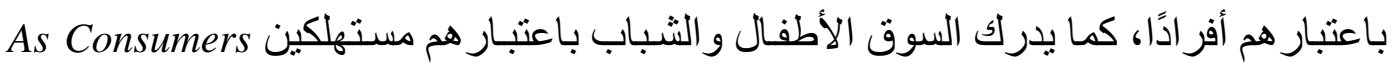

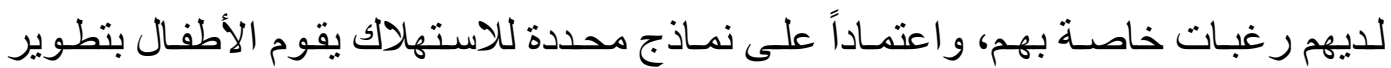
الثقافات الفر عية Sub Cultures الخاصة بهم. (Y) وهكذا أصبح ينظر إلى الأطفال كأفر اد داخل نطاق الأسرة وليس فقط باعتبار هم

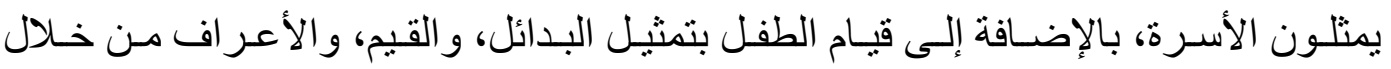

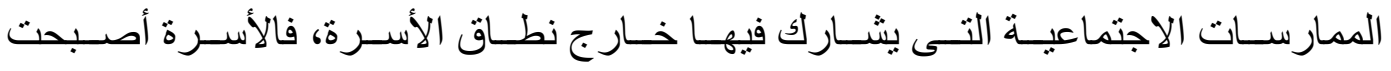

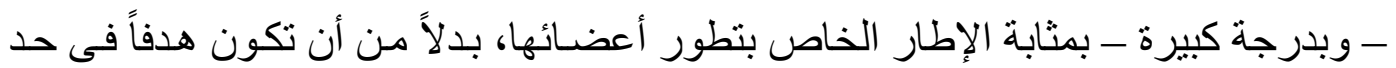
ذاتها. (^)

ومن ناحية أخرى ينبين لنا اختلاف نظم التعليم داخل المجتمعات الإنسانية المعاصرة ونقصد بذلك الانتقال من التعليم المؤسسى Institutionalized Education - الذى يُفرض على الئ

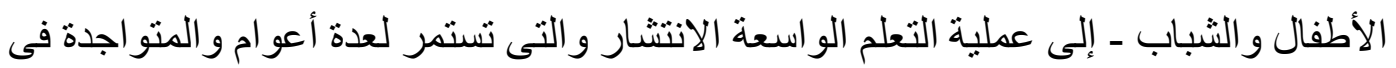
إطار عالم الحياة اليومية، وبذلك يمكن القول بإنه لم تعد عملية التعلم تتنهى بصفة استثنائية

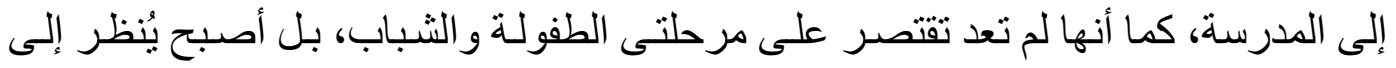

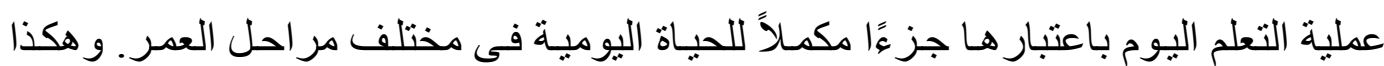
يمكن القول بإن نمو وتطور التعليم المؤسسى، و الانتقال إلى عملية التعلم المتو اجدة فى إطـار

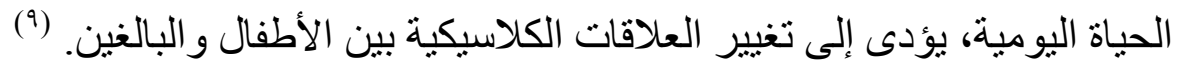


ويتبين فى ضـو هاسبق أن عمليـة التعلم مستمرة خـارج نطـاق المدرسـة وذلك فىى إطـار عـالم الحبـاة اليوميـة، حيث يكتسـب الطفل العديــ مـن المعـارف ، و الخبـرات، و القبم الإنسـانية و التى يمكن الاسـفادة منهـا فـى عمليـة التنشـئة الاجتماعيـة على المو اطنـة وهـذا ماسوف نبرزه بالتفصيل فى المحور القادم.

\section{ثانياً: الطقولة وتعليم المواطنة: قراعة أولية:}

يزخر تراث العلم الاجتماعى بالعديد من التعريفات حول مفهوم المواطنة حيث تعرف بإنها انتماء و عضوية كاملة ومتسـاوية فى المجتمع بمـا يترتب عليها من حقوق وو اجبات، و هو ما يعنى أن كافة أبناء الثعب الذين يعيشون داخل الوطن سواسية بدون أدنى تمييز قائم

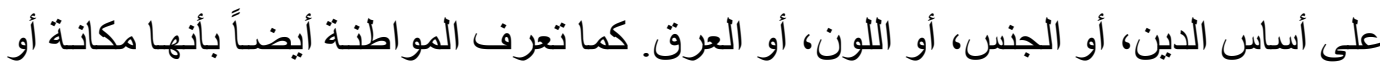
علاقة اجتماعيـة تقوم بين شـصص طبيعى وبين مجتمـع سياسـى (الدولـة)، ومن خـلال هذه العلاقة يقدم الطرف الأول الو لاء للوطن، ويتولى الطرف الثانى الحماية، وتتسم هذه العلاقـة بين الثـخص و الدولة بالمسـاو اة أمـام القانون، وهكذا يمكن النظر للمو اطنـة على اعتبار هـا

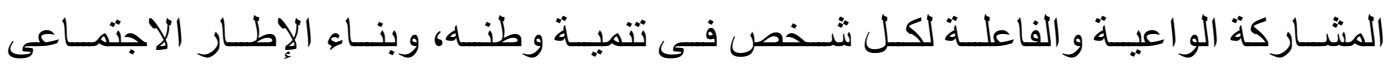
و الاقتصادى، و السياسى، وكذلك الثقافى للاولة. (·)

فالمو اطنة من حق الأفر اد الذين يشـغلون مكانـة معينـة فى بنـاء المجتمع، ولأن هذه

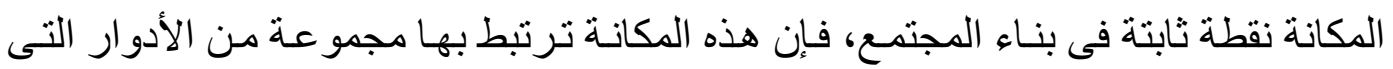

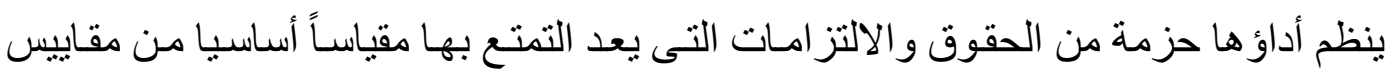
(1') (المو اطنة.

كما تُعبر المواطنـة عن حركة الأفر اد فى اتجـاه إثبات وجودهم فى إطـار جماعـة بعينها بحيث تتجاوز هذه الحركة الانتمـاءات الأضيق إلى الانتمـاءات الأرحب، أى تجاوز

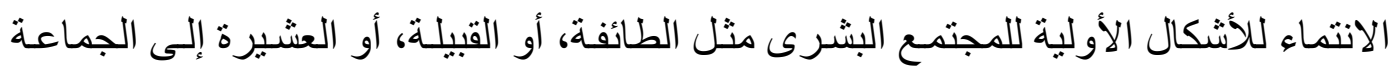
الوطنية، كما تعكس المواطنة علاقة بين طرفين، أما الأول فهو الفرد والتعبير السياسىى عنه هو "المو اطن"، والطرف الثانى هو الوطن والتعبير السياسى عنه هو "الدولة"، وحتى تكون هنالك علاقة عضوية يشترط فى الفرد الذى يحمل صفة المو اطن التو اجد المادى، وأن تتو افر

فى الوطن الحضور المعنوى و الوظيفى للدولة. (rir)

وتتضمن المو اطنة ثناثة عناصر : العنصر القانونى؛ ويركز على الحقوق التى يجب أن تكفلها الدولة للمو اطنين على قدم المساواة دون أى تمبيز على أساس الدين، أو الجنس، أو 
العرف، ويقابل هذا التظظيم القانونى الالتز امات التىى يجب أن يفى بها المـواطن تجـاه الدولة والعنصـر السـلوكى؛ ويعنى بالممارسـات التى تعكس درجـة النضـج التقافى الذى يتمتع بـهـ المو اطن، وقدرة الدولـة على أن توفر للفرد متطلبـات الحيـاة الملائمـة، والعنصر الوجدانى ويتضــن شـعور الفـرد بالانتمـاء و الـو لاء للاولـة بمـا يـؤدى إلـى الاحتـر ام و الالتزز ام القوى

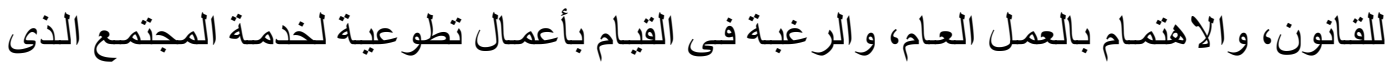
يعيش فيه بدءاً من التضحية بمصالحه الخاصة، و انتهاءً إلى الاستعداد للتضـية بـالنفس فى بـ سبيل الدفاع عن الدولة ضد ماقد تتعرض له من تهديدات ومخاطر. (rir) أمـا عـن تعليم المواطنـة، فإنـه يمكن القول إن هنـالك العديـد مـن المصطلحات التىى تستخدم على نحو متبـادل داخل تر اث العلم الاجتمـاعى لوصف تلك العملية ، ومن أبرز هـا "التربيـة المدنيـة"، و "التربيـة مـن أجلـل المواطنـة"، و "تعليم المواطنـة" وبغض النظر عن اختلاف التسميات فإن هنالك العديد من التعريفات التى طرحت حول تللك المصطلحات، فعلى سبيل المثنال تشـير التربيـة المدنيـة إلى تلك العملية التى يقصد بها تقديم المعرفة الأساسية بالقو اعد المؤسسية Institutionalized Rules التى تتعلق بـالحقوق والالتز امـات وتتضـن تعليماً ينمى القدر ات اللازمة للمشاركة النشطة فى العمليات الاجتماعية والسياسية. كما بشير سالمون Salomone إلى أن التربية المدنية (التربية من أجل المواطنة الديمقر اطية) يقصد بها تلك العمليـة التى تتضـمن نقل المعتقدات والقيم السياسية إلى الصـغار، و التىى تمثل حجر

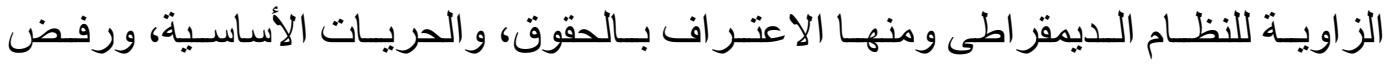
العنصـرية و غير هـا مـن كافـة أشنكال التمبيز باعتبار هـا انتهاكـات لكر امـة الفرد وو اجب كل

المو اطنين نحو دعم المؤسسات التى تجسد الإحساس المشترك بالعدل وسيادة القانون. (ء ()

ومن بين التعريفات الأخرى لمفهوم تعليم المو اطنة بأنها عمليـة تهدف إلى توعية

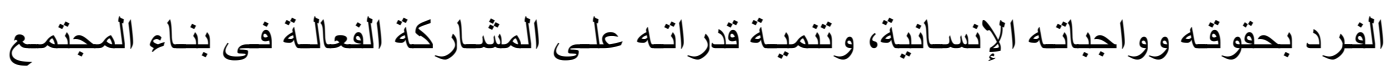
و مؤسساته، وتحمل المسئولية، وتكوين اتجاهات إيجابية نحو الذات والآخرين. أما المجمو عة Advisory Group on الاستشارية للتربية من أجل المواطنة وتعليم الديمقر اطية فى المدارس Education for Citizenship and the Teaching of Democracy in Schools وزارة التعليم البريطانية فى نوفمبر (99 ( 99 )، فتعرف التربية الفعالة من أجل المو اطنة بأنها تعنى ثناثة أثياء متر ابطة ومتداخلة وهى أن يتعلم الأطفال السـوك المسئول اجتماعياً داخل الفصـل وخارجـه، ونحـو مـن هـم داخـل السـلطة ونحـو بعضـهم البعض، وكذللك الانخـر اط اط

و المشاركة فى المجتمع من خلال الخدمة التطوعية. (10) 
و هناك تعريف يتطابق مع التعريف السـابق وهو أن التربية من أجل المواطنة هى

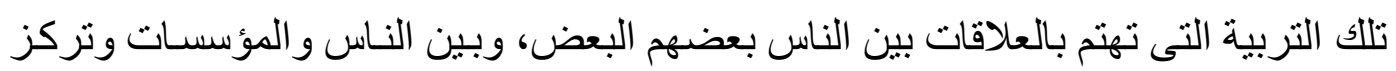
على تنمية الأفر اد كفاعلين اجتماعيين Social Agents يقوم بينهم الاعتمـاد المتبادل، وتؤكد

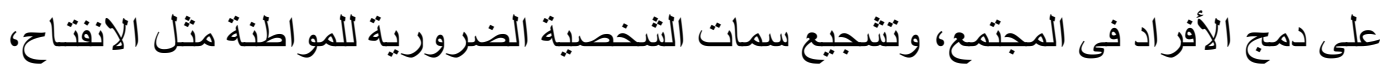

$$
\text { و المساءلة ومهار ات المشاركة. }
$$

ووفقاً للتعريف الوارد فى الدر اسـة الدولية للتعليم الددنى و المو اطنة و التى أجريت

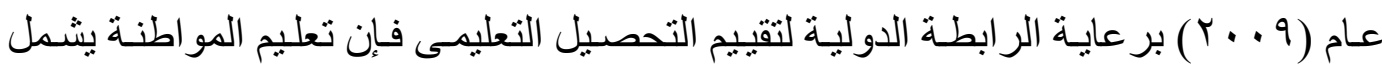

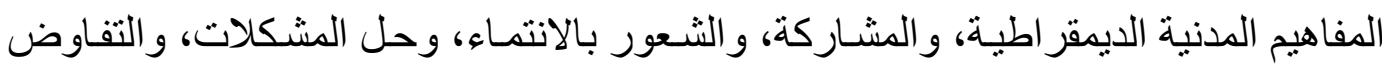

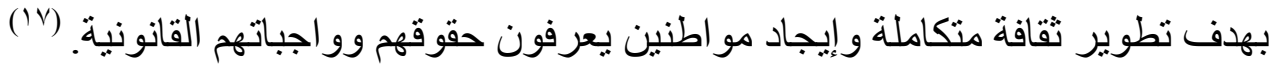
أما عن بدايات الاهتمام بتعليم المواطنة ، فإنه يمكن القول إنه منذ تأسبس المدارس

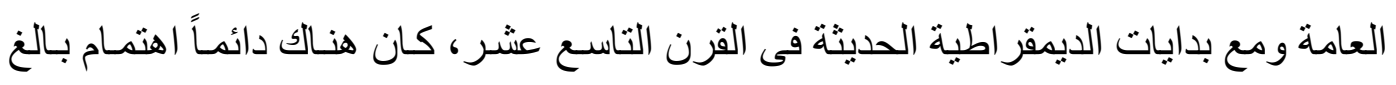

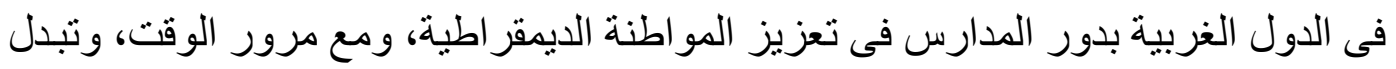

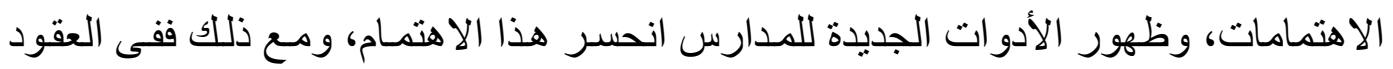
الأخيرة و لا سيما مـع المخـاوف بشـأن زيـادة التباعد بين المو اطنين، و وعدم القيام بـالأدوار

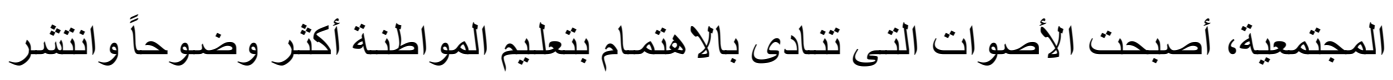

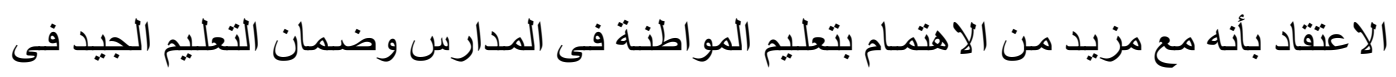

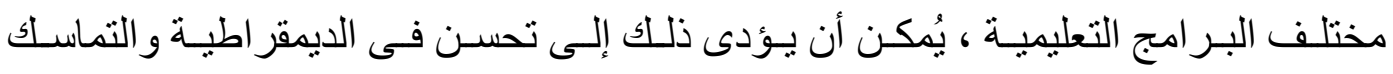

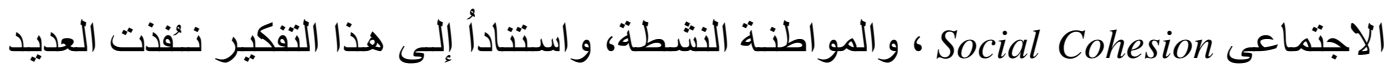

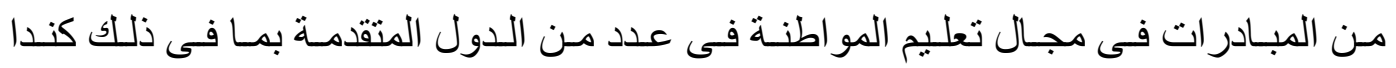

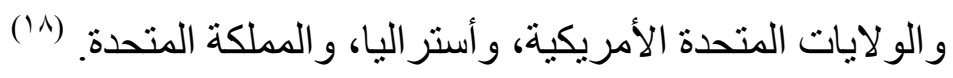

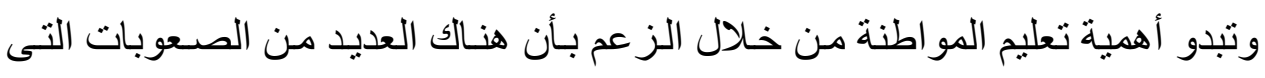

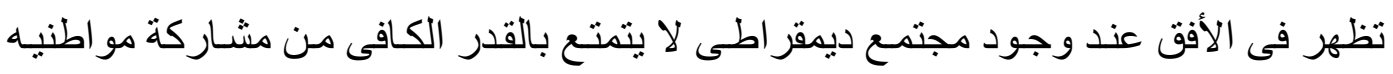

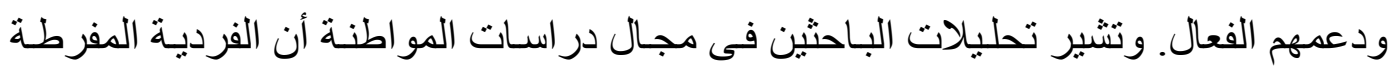

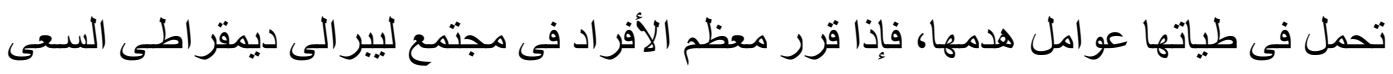

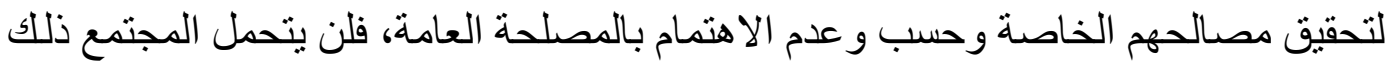
ولذلك فإنه لكى يستمر المجتمع الديمقر اطى فإنه ينطلب - على مستوى معين - دعم القيم

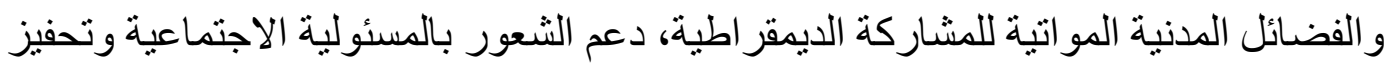

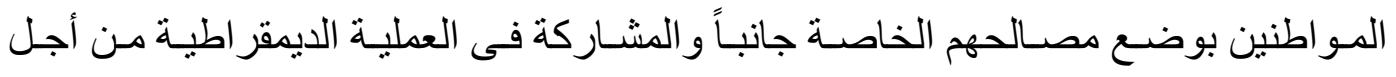


المصـلحة العامـة للمجتهـع ككل. ويمكن القول إنـه بـدون روح العـل الجمـاعى و المو اطنـة النشطة فمن غبر المرجح أن يظل المجتمع الديمقر اطى الساعى نحو حماية حقوق أفر اده آمناً لفترة طويلة. (19)

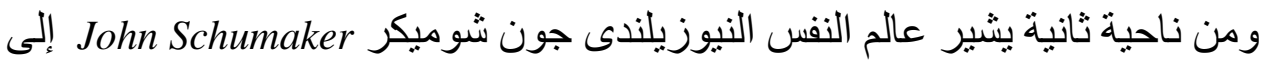

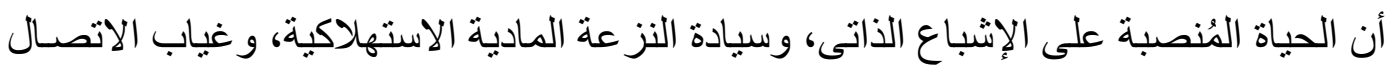

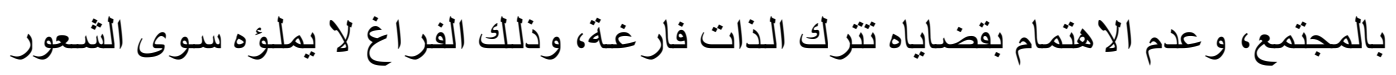

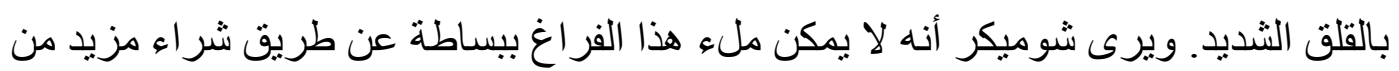

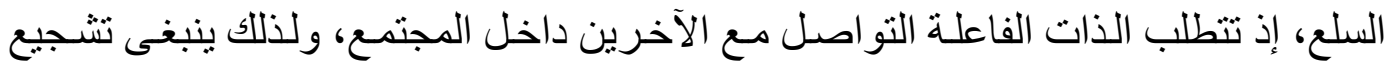

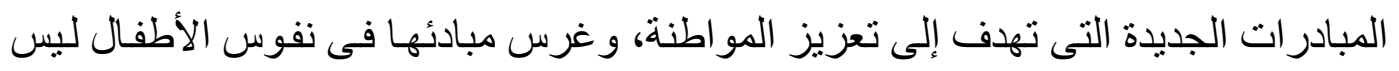

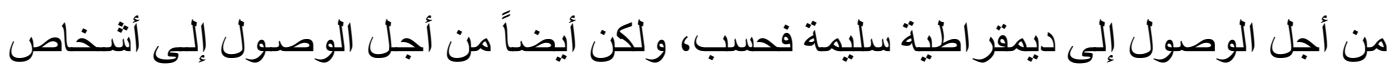

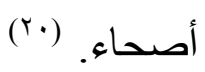

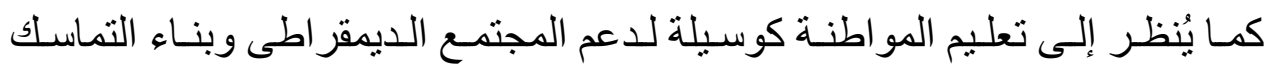

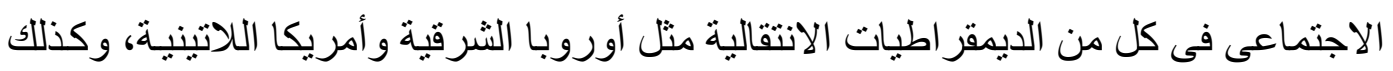

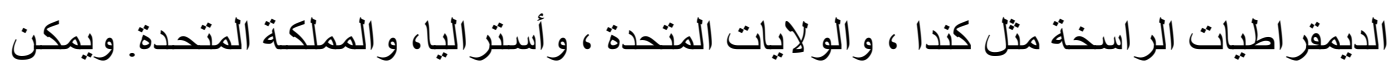
القول إنه فى الديمقر اطيات الر اسخة كان هنالك مخـاوف من تنـامى الاتجـاه نحو الانفصـال

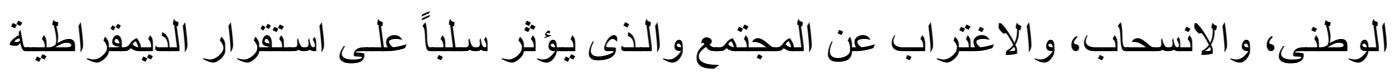

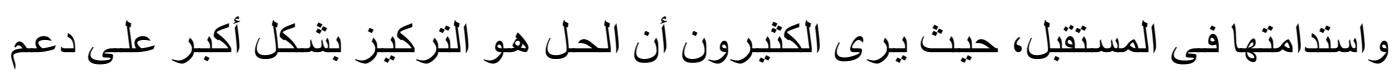

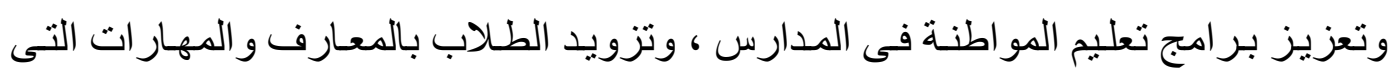

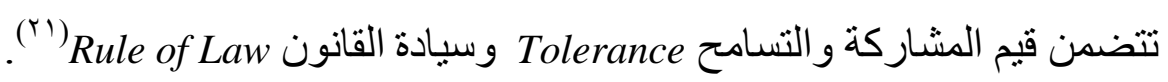

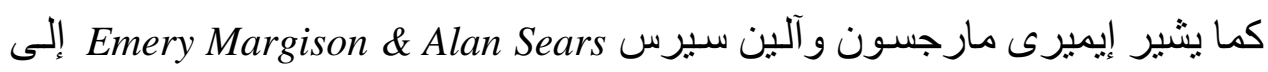

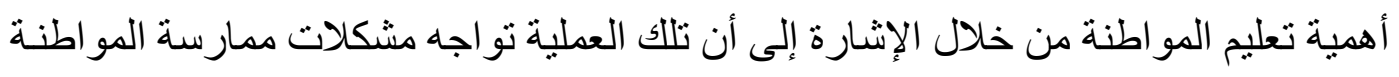

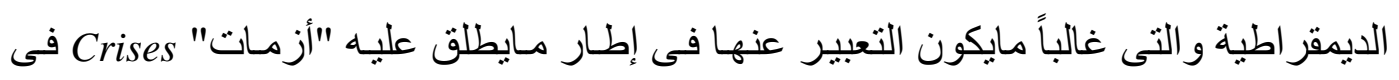

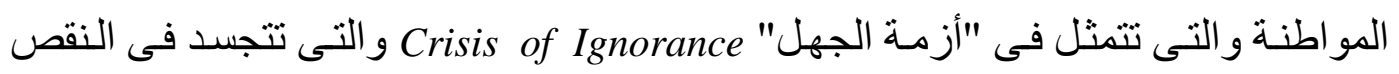

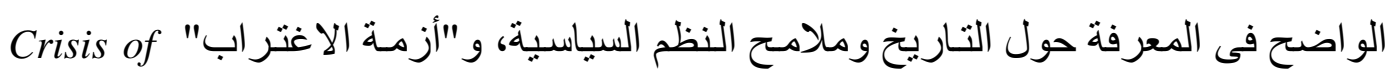
Alientaion

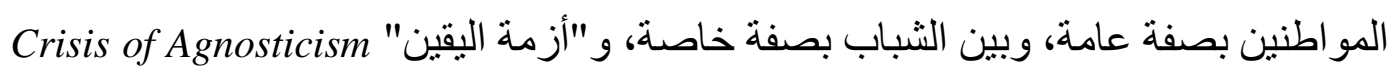

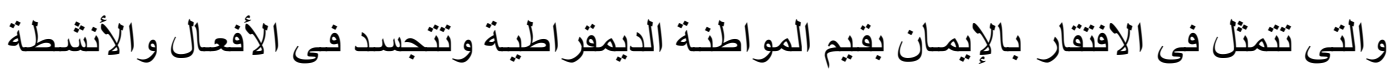

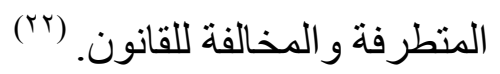


ويذكر كل من ألين سيرس و أندرو هوجل Alan Sears \& Andrew Hughes بأن

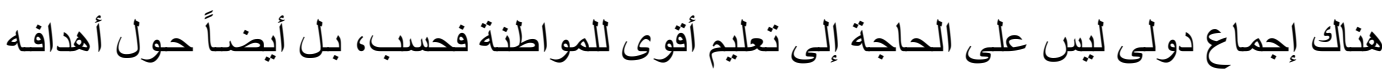
ووسائله العامة، فمن المتفق عليه على نطاق واسع أن الهدف لا يقتصر على تحسين المعرفة لهائ

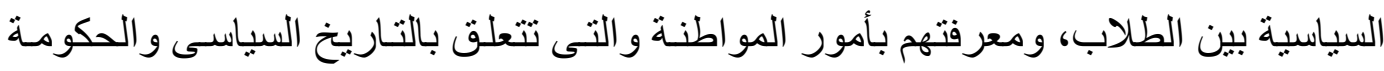

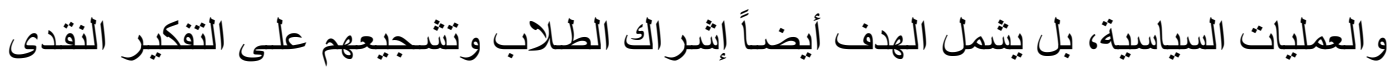

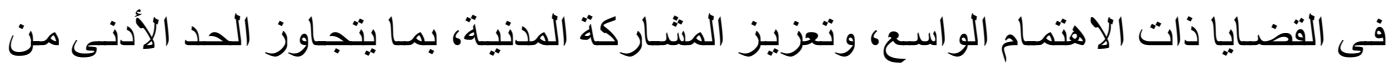

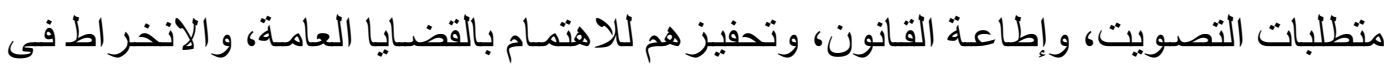

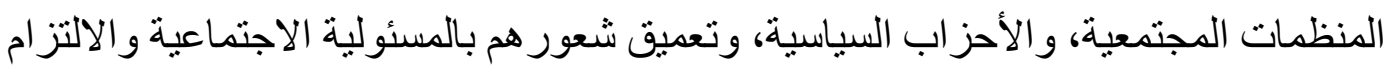

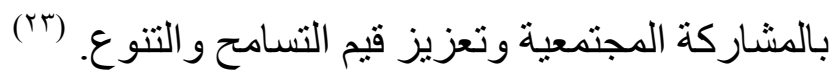

وإجمالاً يمكن أن نبرز أهمية تعليم الأطفال المواطنة من خـلال التركيز على عملية التربية على حقوق الإنسان حيث تشير المادة (r \&) من اتفاقية حقوق الأطفال إلى أن للأطفال

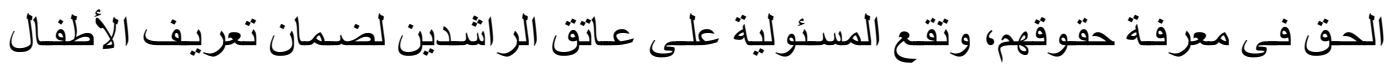

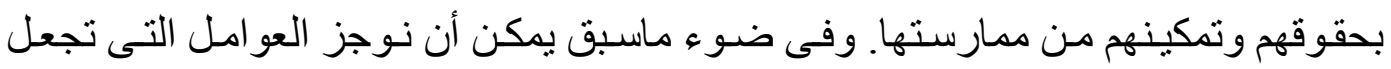

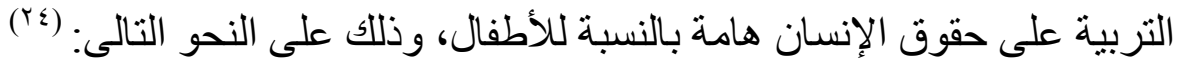

1ـ احترام حقوق الإنسـان: إن معرفة الحقوق تعتبر الخطوة الأولى لزيـادة احتر ام حقوق الإنسان ، ففى الأماكن التى يكون الأطفال على وعى بحقوقهم، يكون هناك احتر ام أكبر

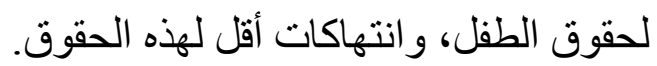

r- الاعتراف العالمى بقيم حقوق الإنسان: إن الر اشدين الذين يعملون مع الأطفال يو اجهون

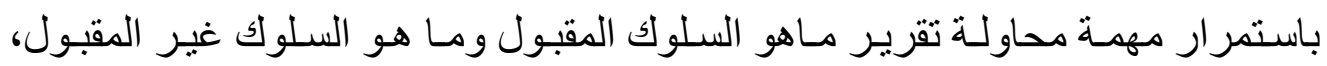

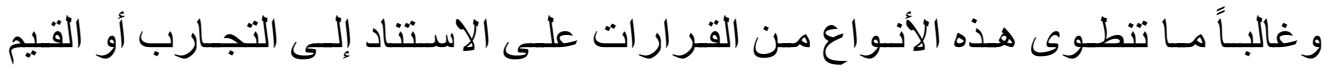

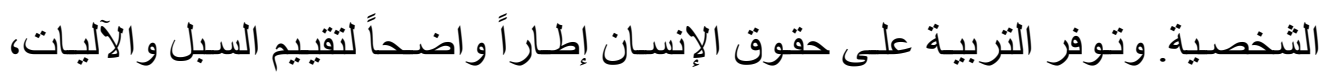
وكذلك توقيت التدخل من خلال الإشارة إلى القيم الإنسانية المعترف بها عالميًا، والتى التى تنبثق مباشرة من الإعلان العالمى لحقوق الإنسان.

rــ تنميـة احترام الذات و المشـاركة النشطة: عندما يصبح الأطفال على و عى بحقوقهم،

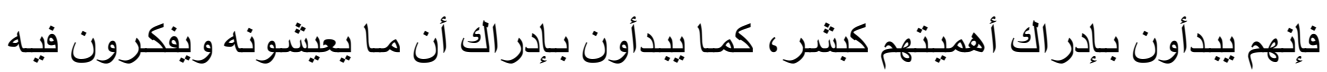


ويشعرون به أمر له قيمة، وأن بوسعهم المسـاهمة الإيجابية فى حياة الجماعـة والأسرة

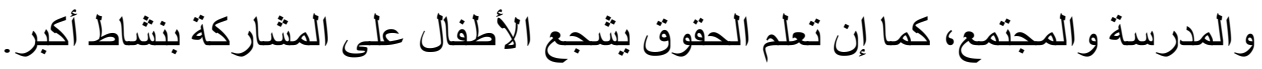

عـ تعزيز السلوك الإيجابى: تعتبر التربية على حقوق الإنسـان إحدى طرق التشجيع على السلوك الإيجابى الأكثر فعالية لأنها تنطوى على التفكير النقدى وتعزيز إحساس الطفل التسل

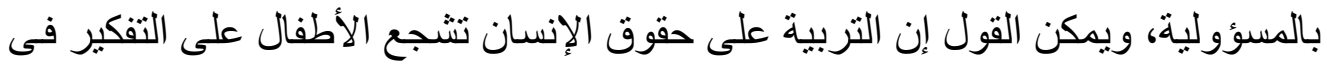
كيفية التفاعل مع الآخرين، وكيفية تغيير سلوكهم، بحيث تعكس قيم حقوق الإنسان على العى لإنى

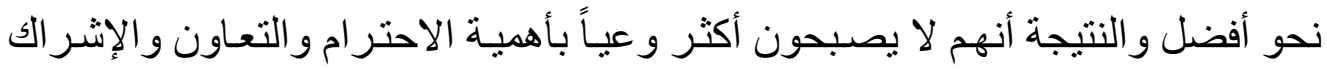
فحسب، و إنما أكثر استعداداً لإدماج هذه القيم فى الممارسة العملية فى حياتهم اليومية.

ثالثاً: الرؤى السوسيولوجية للمو اطنة النشطة:

تتضمن الرؤي السوسيولوجية المفسرة للمو اطنة النشطة التركيز على منظور عالم

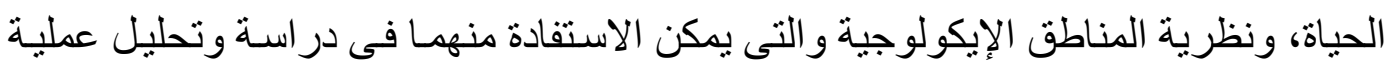

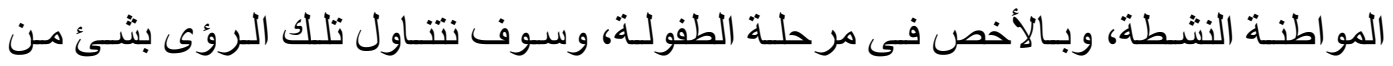

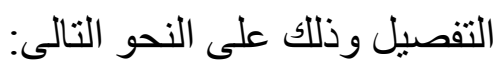

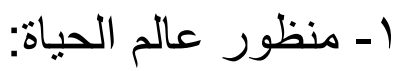

يهتم منظور عالم الحياة Life-world Perspective بدر اسة وتحليل المواطنة النشطة

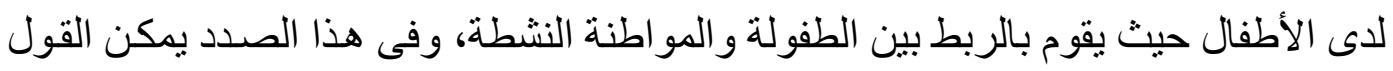

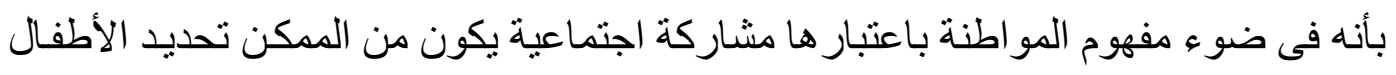

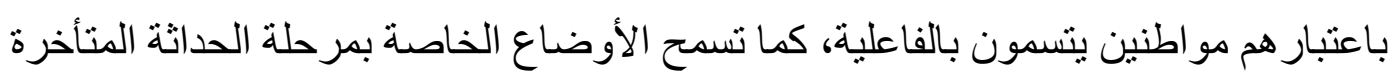
Late Modernity Social Actors

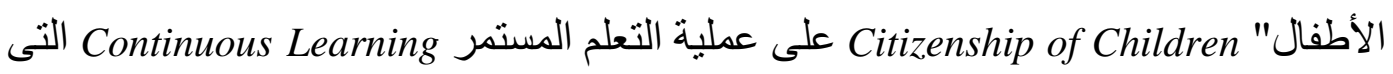

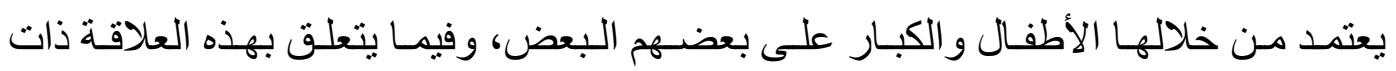

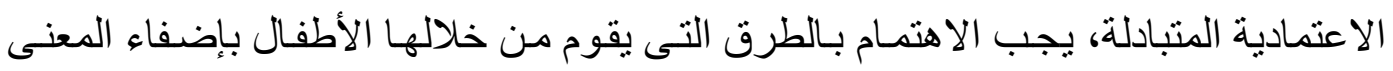

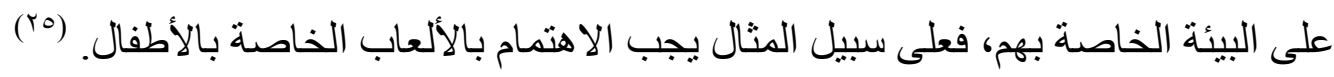

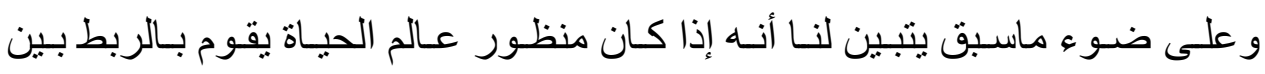
المشاركة و المو اطنة من خلال النظر إلى المشاركة (أنثعر بتو اجدى داخل المجتمع و إمكانية 


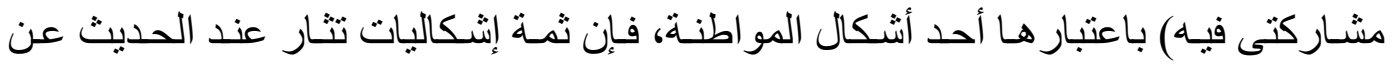

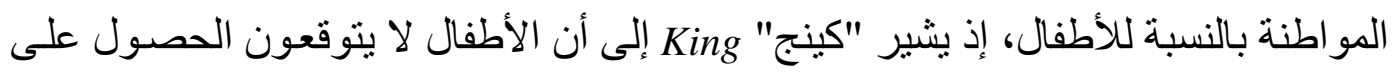

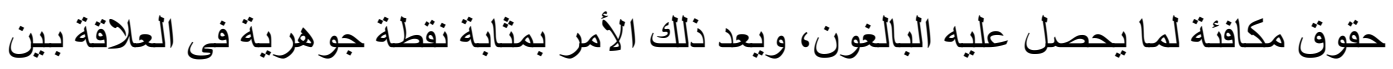

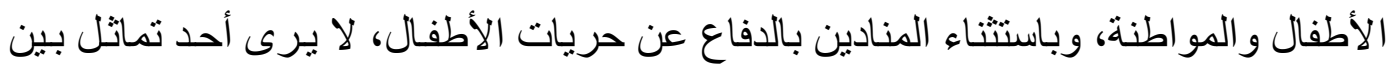

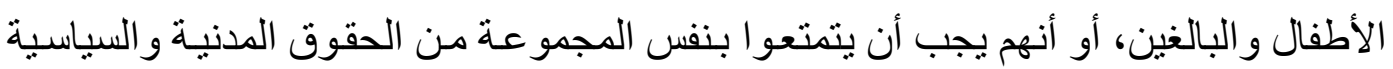

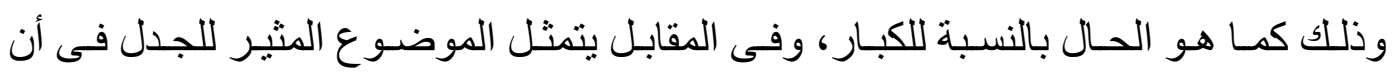

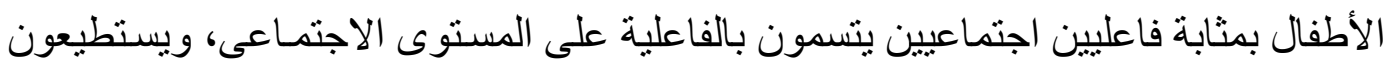

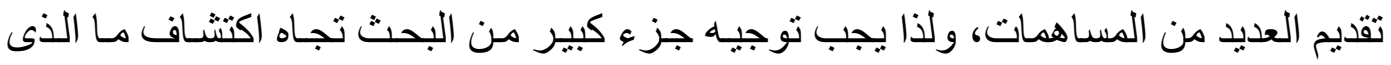

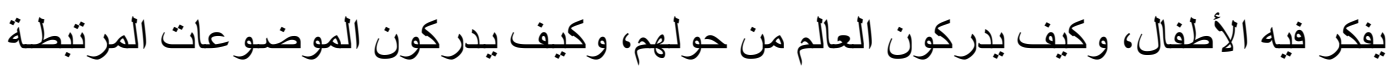

و هكذا يمكن القول بإنه بالنسبة لمشروع المو اطنة ـ أيسّا كان الثكل الخـاص بـه - لا لاعل

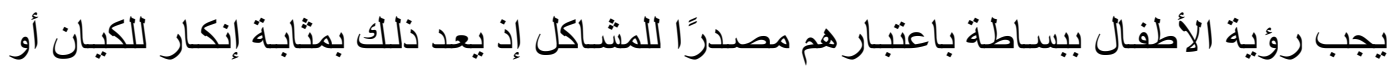

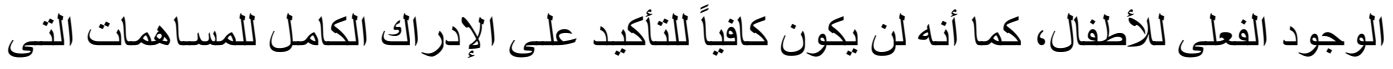

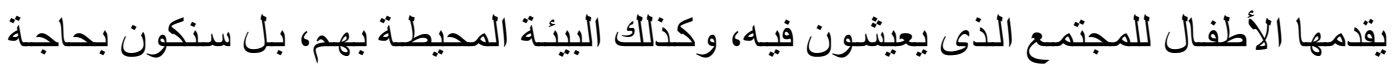

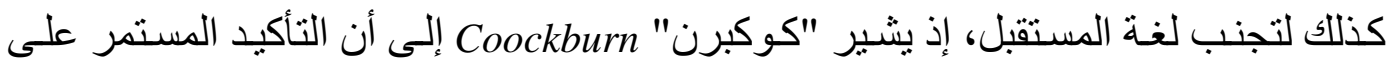

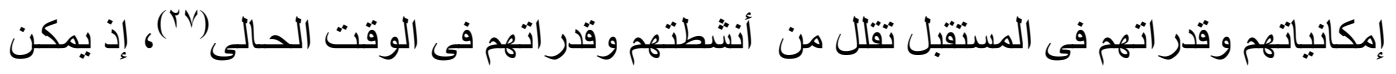

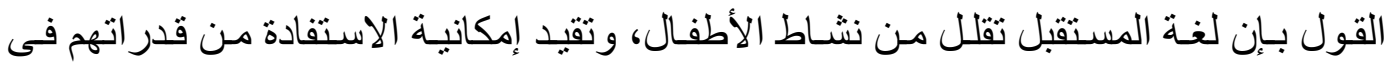

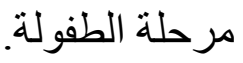

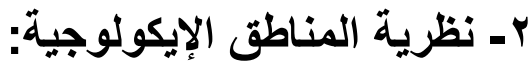

إذا كانت البيئة عبارة عن تفاعلات مركبة يمكن من خلالها تشكيل كينونة الأطفال ووجودهم

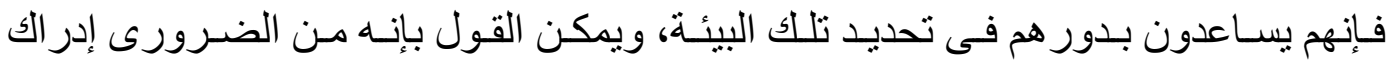

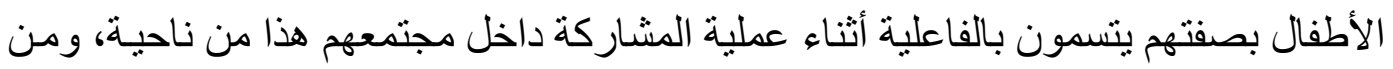

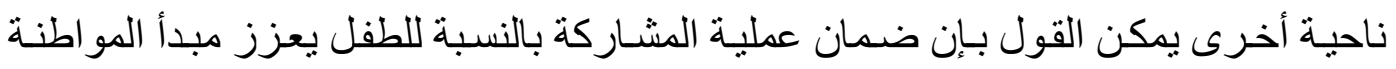

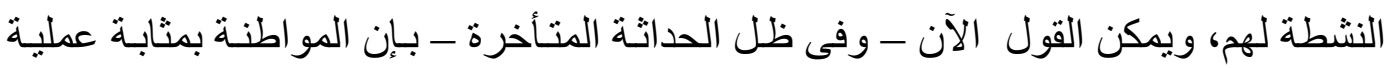

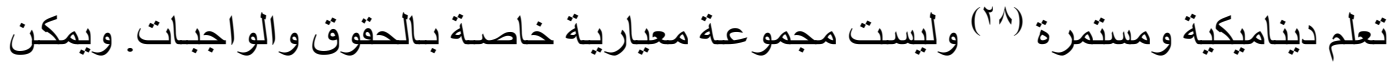

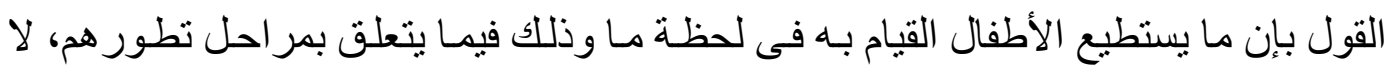

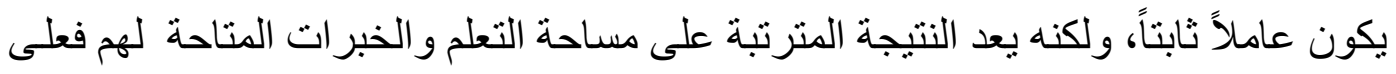


سبيل الهثال يتبين من خلال مشاركة الأطفال فى تنظيم البيئة التى يعيثون فيها أن إمكانياتهم السلوكية تنظور وتتمو مع مرور الوقت، ويشير "روبرت كولز " Robert Coles بقوله "بإننا

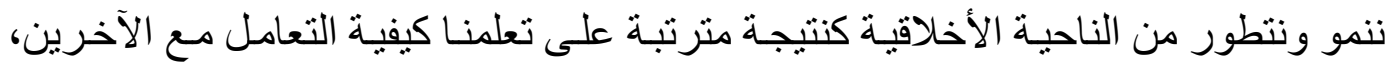

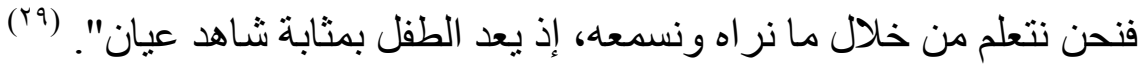
وعلى ضوء ماسبق سوف نقوم بتوضيح عملية التعلم من خلال الاستناد إلى "نظرية

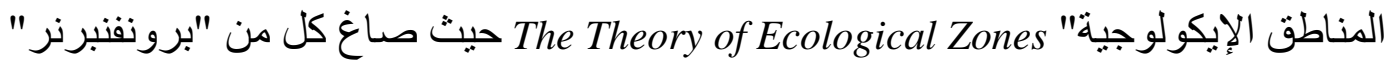
Baacke "Bronfenbrenner ( $19 \mathrm{VV}$ )

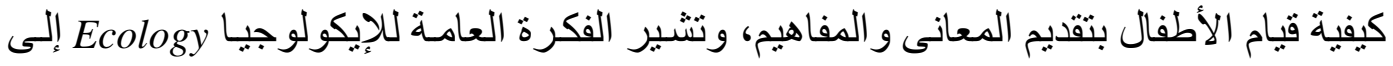

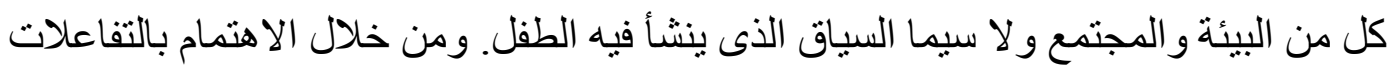

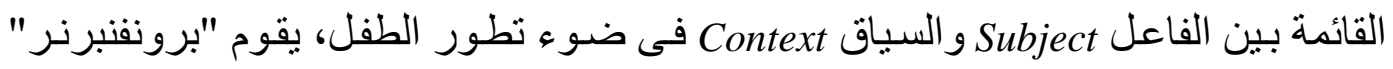

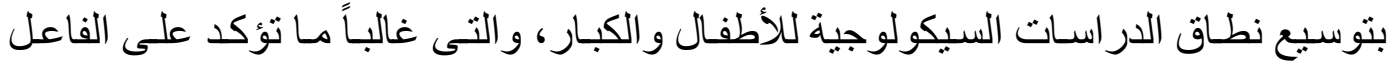

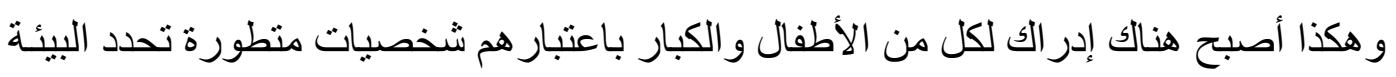

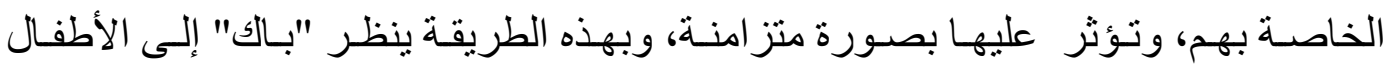

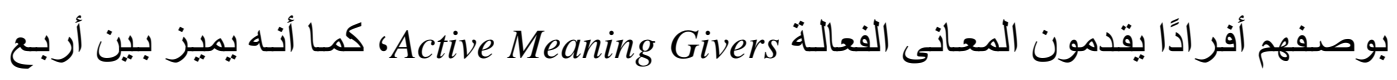

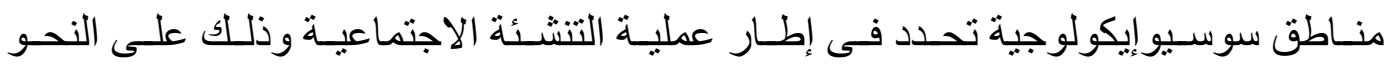
التالى:(r·)

1- المنطقة الأولى؛ ويطلق عليها "المنطقة الإيكولوجية" Ecological Zone داخل المنزل

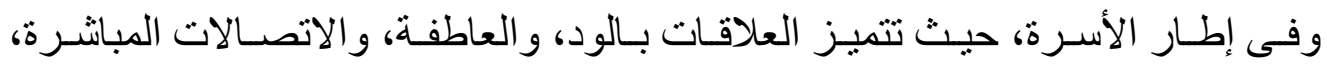
و الاعتماد بصورة متز ايدة على الأسرة.

r- المنطقة الثانية؛ وتتمثل فى "التقارب الإيكولوجى" Ecological Proximity و الذى الذى

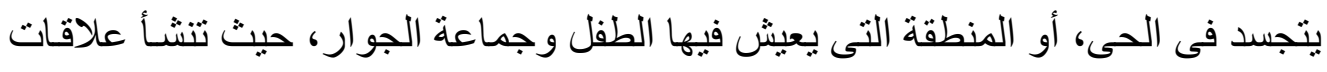

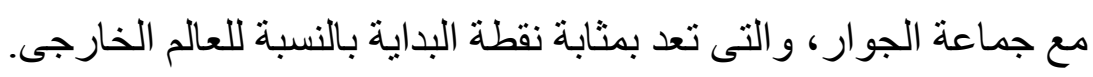
r- المنطقة الثالثة؛ وتتجسد فى "القطاع الإيكولوجى" Ecological Sector إذ توضح تلك الك

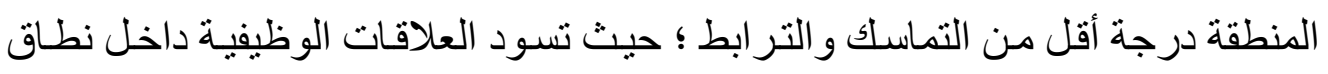

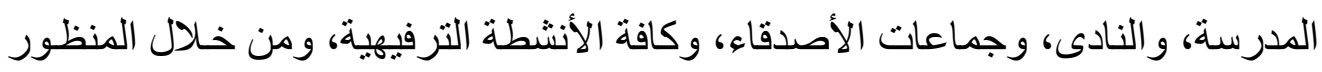

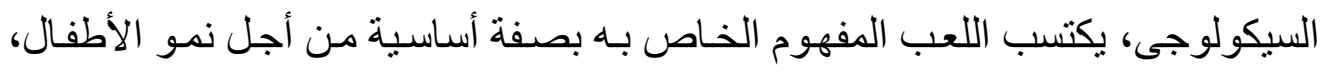

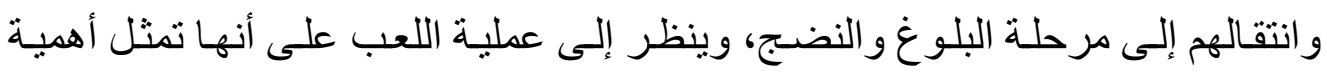


كبيرة بالنسبة لنمو الأطفال بصورة صحية وجيدة، كما يشكل اللعب طريقة هامة فى

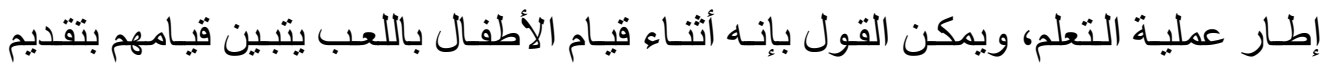
المعانى، حيث يمكنهم التدخل بصورة فعالة فى البيئة المحيطة بهم، كمـا أنهم يقومون

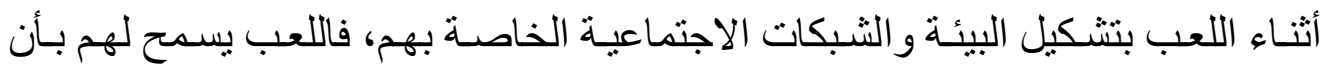

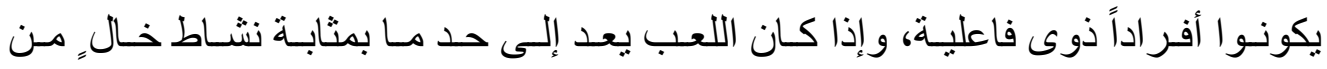
الثروط، فإنه ينسم بالأهمية بالنسبة للأطفال، و أثناء عملية اللعب يقوم الأطفال بالتفاعل

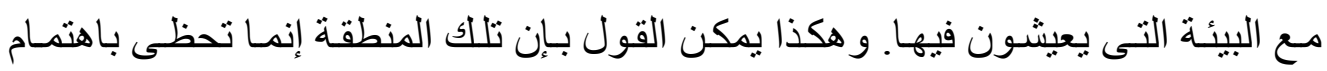
خاص إذ يو اجه الأطفال توقعات خاصة أثناء ممارساتهم للأنشطة المختلفة. ع- المنطقة الرابعة وتتمثل فى "المحيط الإيكولوجى" Ecological Periphery ، إذ يتسم

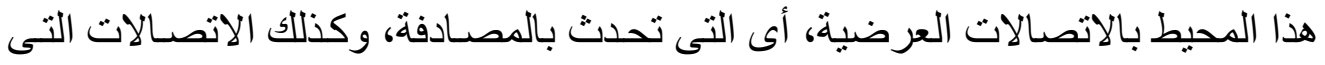

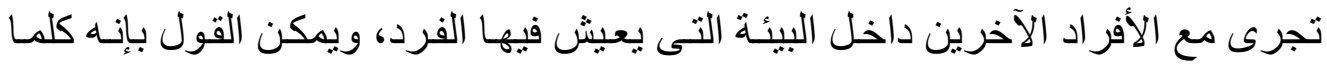

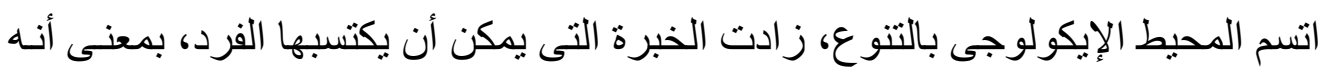

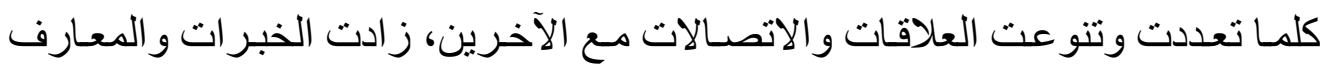

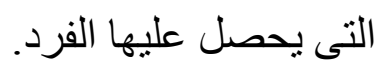

ويتضح لنا فى ضو ه ماسبق أن تحديد المناطق الإيكولوجية يتباين فى ضو و المرحلة

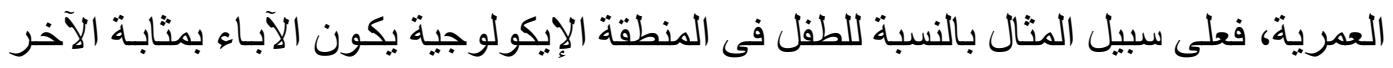
القريب من الأطفال، حيث يتفاعل معهم الأطفال فى إطـار مجمو عـة متنو عـة من الأماكن.

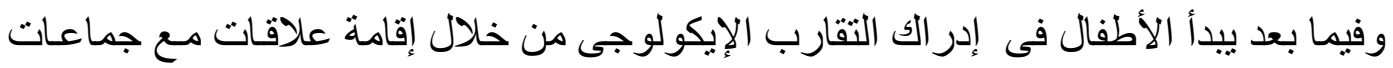

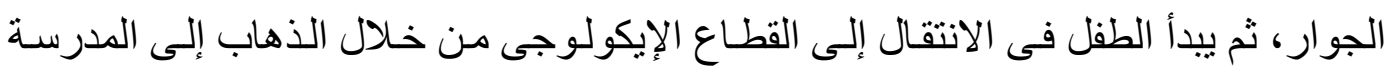

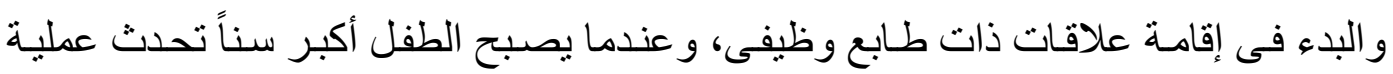
الانتقال إلى المحيط الإيكولوجى، حيث تزداد الأنشطة التى يقوم بها الأطفال، ولنال، وهكذا يتسم الأطفال فى كل مكان و عبر التاريخ بأنهم أفر اد يقدمون المعانى بصورة الأسطة فعالة.

\begin{tabular}{|c|c|c|c|}
\hline "(أمسيط الإيكولوجى)" & "المدرسة الإيكولوجى" اللعب) & "التقارب الإيكولوجى" & "المنطقة الإيكولوجية" \\
\hline
\end{tabular}

"رسم توضيحى يبين مراحل انتقال الطقل بين المناطق الإيكولوجية" 


\section{المبحث الثانى: تعليم المواطنة بين الحقوق الأساسية والقيم الإنسانية}

سوف نتناول فى هذا المبحث عدة قضايا ومن أبرزهـا الحقوق الأساسية التى يجب . أن يتمتع بها الأطفال داخل المجتمع والتى تتضمن الحق فى المشـاركة، و الحق فى المعرفة وكذلك الحق فى حماية الخصوصية، كما سوف يتضمن هذا المبحث الإشـارة إلى أبرز القيم الإنسـانية المصـاحبة لعمليـة تعلـيم المو اطنـة للأطفـال، كمـا سـوف نسـتعرض آليـات تعليم المو اطنـة والتى تتمثل فيى الأسـرة، و المدرسـة (النظـام التعليمسى) ، بالإضــافة إلى توضـيح لجوانب القصور فى تعليم المو اطنة.

\section{أولاً: الحقوق الأساسية:}

سوف نركز فـى تناولنـا للحقوق الأساسية التـى يجب أن يتمتـع بهـا الأطفـال داخل مجتمعاتهم الإنسانية على ثناثنة أنماط من الحقوق، ومن أبرزهـا على سبيل المثنال الحق فى المشاركة ، و الحق فى المعرفة، والحق فى الخصوصية، وذللك على النحو التالى:

\section{ا ـ الحق فى المشاركة والتعبير عن الرأى:}

يقصد بالمشاركة بالنسبة للطفل إتاحة الفرصة له لمناقشة الأمور و القضايا التى تؤثر على حياته الثخصية بصـورة مباشـرة، وذلك مـن خـلال الحديث و الحـوار مـع الأشـخاص البالغين داخل المجتمع الذى يعيش فيه، فالأطفال بمثابة أفر اد لديهم كينونـة، ويجب الاستماع إلى رؤيتهم وتصور اتهم حول الو اقع المجتمعى الذى يعيشون بداخله، و التى يجب أن تُحترم

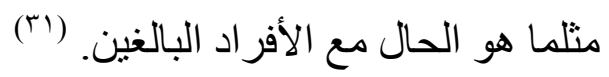

وقد أثـارت المـادة (Y I ) مـن اتفاقيـة حقوق الطفل و التىى اعتمدتها الجمعيـة العامـة

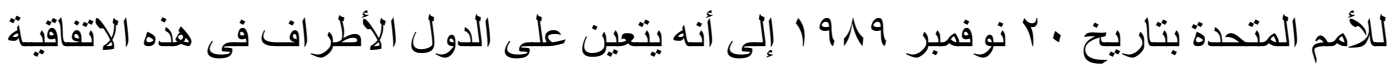

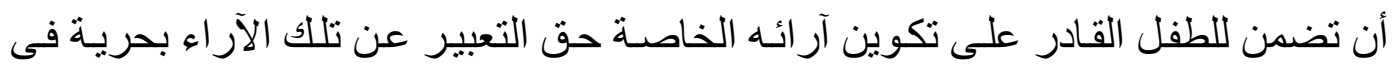
جميع الموضو عات المتعلقة بالطفل، وأن يكون الاهتمـام بـآر اء الطفل وفقاً لمرحلته العمريـة

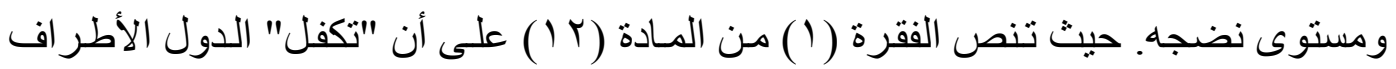
للطفل حق التعبير عن أدائه بحريـة، وعبـارة "تكفل" لهـا طـابع قانونى حيث لا تدع للـدول الأطر اف أى مجال للتأويل، و عليـه فـإن الدول ملزمـة بشكل صـارم باتخـاذ التدابير الملائمـة لإعمال الحق لجميع الأطفال. كما تكفل الدول الأطر اف حق الاستماع إلى كل طفل "قادر على تكوين آر ائه الخاصـة"، و لا يبنغى النظر إلى هذه الجملة على أنها تقييد، و إنمـا إلز ام 
للاول بتقييم قدرة الطفل على تكوين رأى مستقل إلى أبعد حد ممكن، ويعنى هذا أن الدول لا

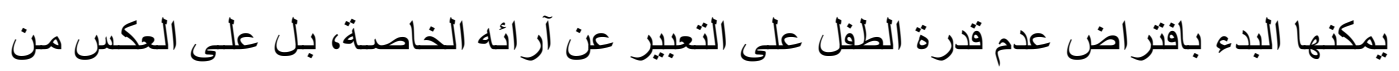

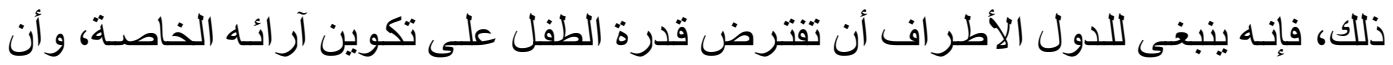

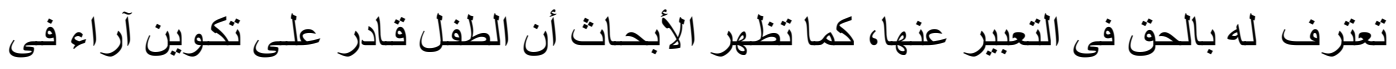

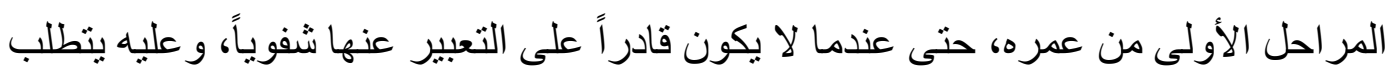

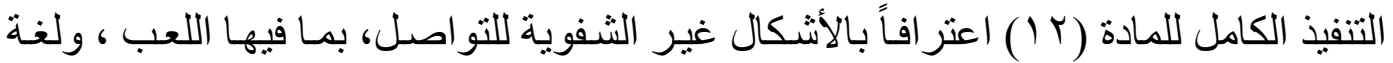

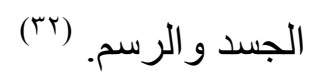

ومن الضرورى فى ضوء ماسبق أن ندرك بوضوح الدلالات الضمنية للمادة (r ا ()

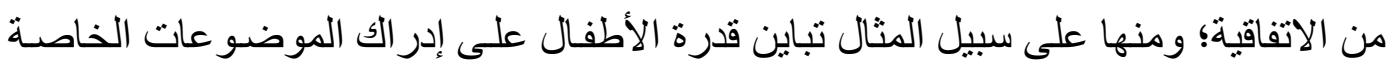

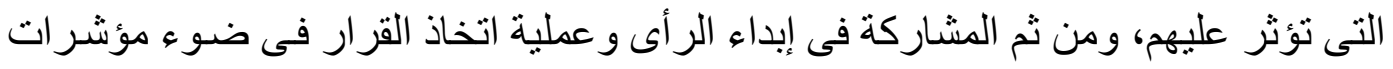

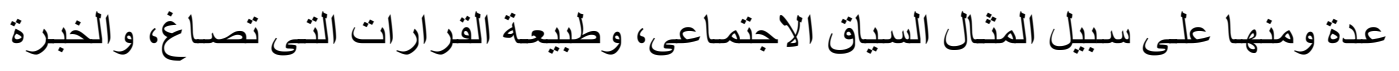
الحياتية لدى الأطفال، وكذللك مستوى الدعم الخاص بالأفر اد البالغين تجاه الأطفال فى الأسرة

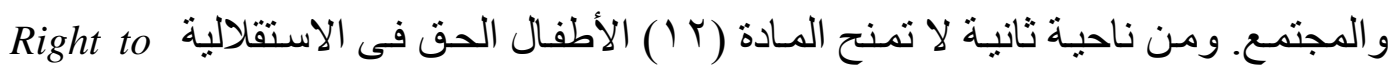
دالاتها Autonomy

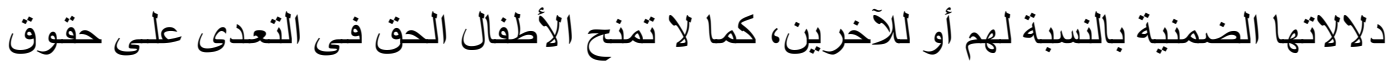

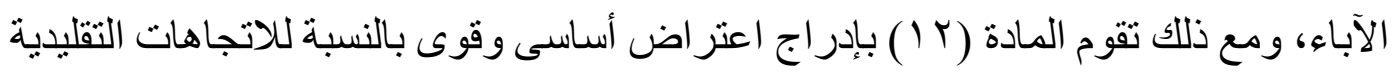

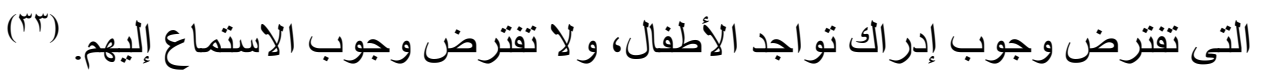
وفى ضوء ماسبق يمكن القول بإنه عند الحديث عن مشاركة الطفل يجب أن نأخذ فى أنى

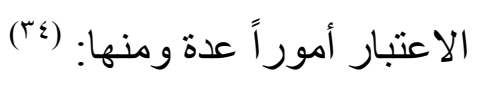

1 - لا يوجد حد أدنى للمرحلة العمرية التى يمكن من خلالها ممارسة حق المشاركة، ومن ثم

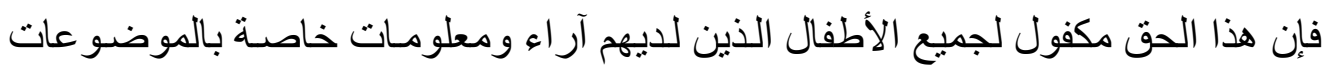

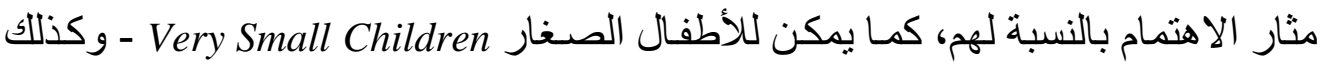

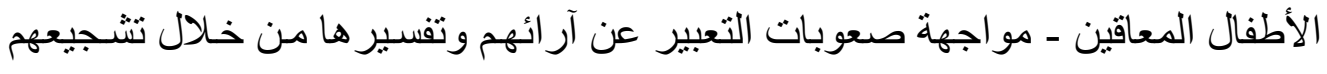
على القيام بأنشطة الرسم، و اللعب، و الكتابة، وكذللك الغناء أو الثعر.

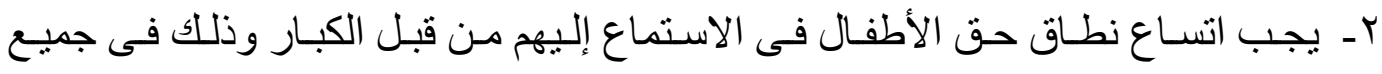

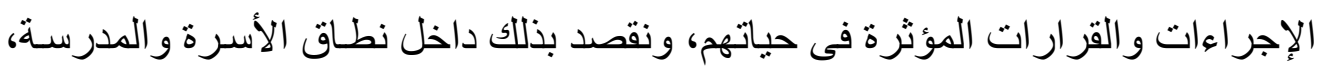
وكذلك فى الموضدو عات المتعلقة بقو انين الأسرة و العمل و التعليم و الرعايـة الصحية، 
وكافـة القضـايا و الســائل المطروحـة للنقاش وذات الدلالـة الضــنية بالنسبة للأطفـال.

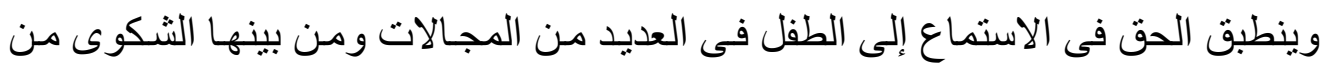

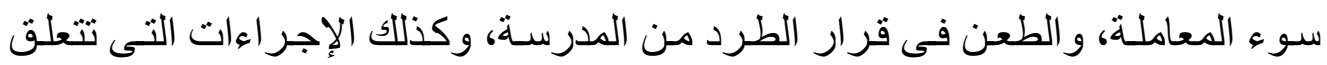

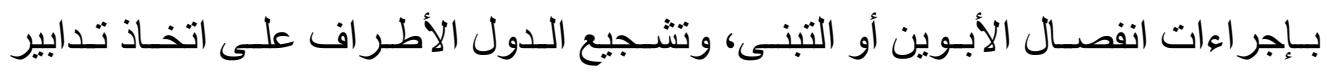

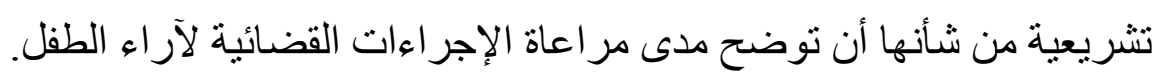

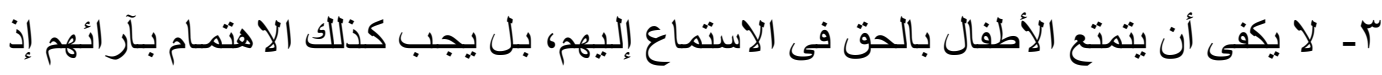

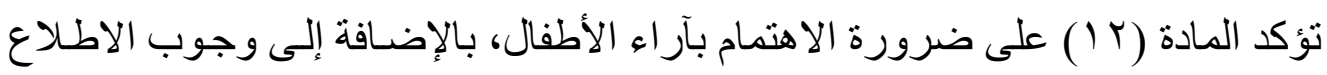
على القرار ات التى تتعلق بهم.

ومجمل القول إنـه إذا كـان لكل فرد الحق فـى التعبير عن ر أيسه عندما يتم اتخـاذ

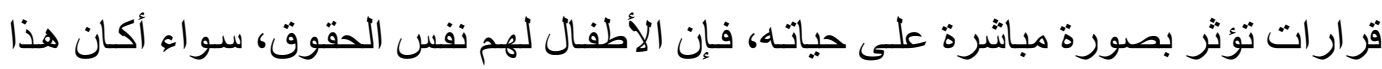

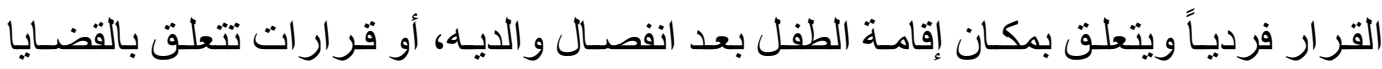

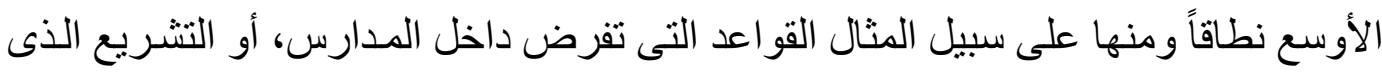
يحدد المرحلة العمرية التى يمكن عندها الطفل أن يعمل طوال الوقت كما هو الحال للبالغين. ونتسـاءل هنـا مـا المجـالات التى يمكن أن يثـارك فيهـا الطفل؟ و الإجابـة على هذا

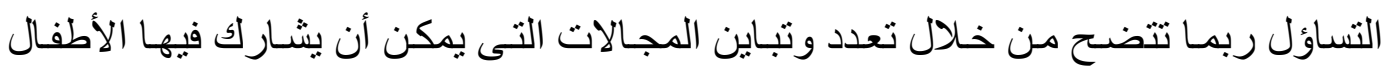

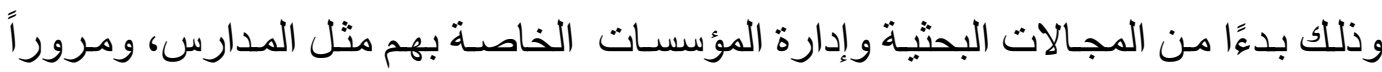

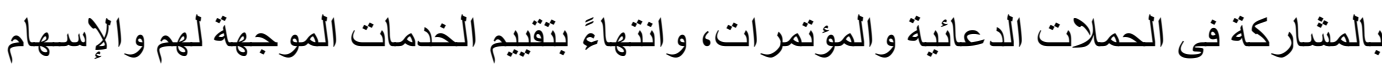

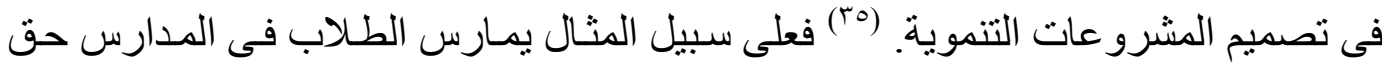

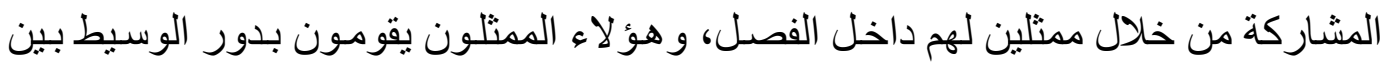

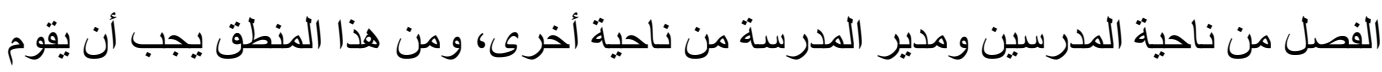

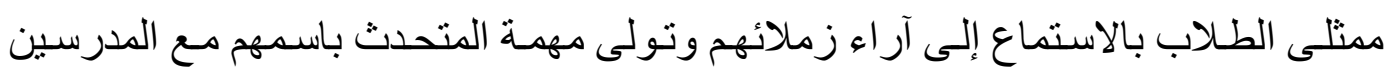

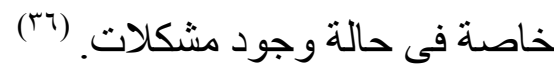
و هكذا يتبين فى ضـوء العرض السـابق لكل مـن مفهوم مشـاركة الطفل، وحدود

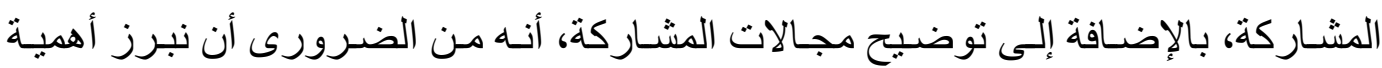

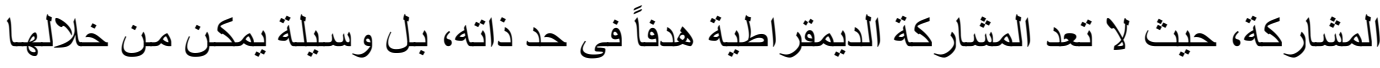

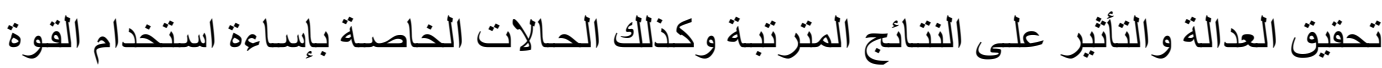
وبعبارة أخرى فإن المشاركة تعد بمثابة حق إجر ائى Procedural Right يمكّن الأطفال من الأن

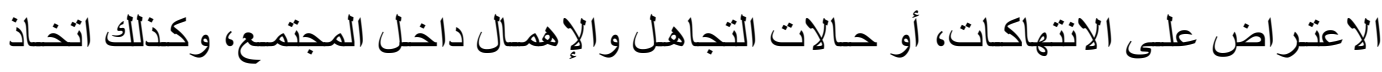


الإجر اءات اللازمة بغرض حماية وتعزيز هذه الحقوق، كما أنها تمكن الأطفال من المساهمة فى تحقيق الاحتر ام للمصالح الخاصة بهم.

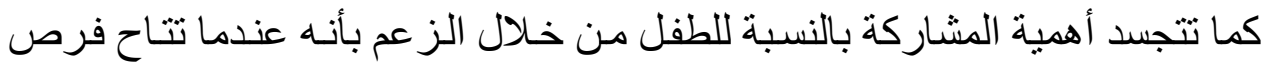

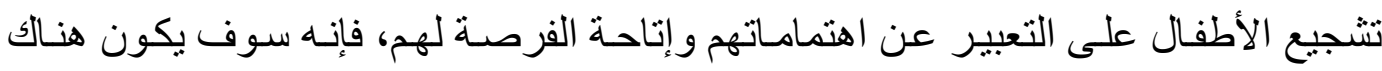

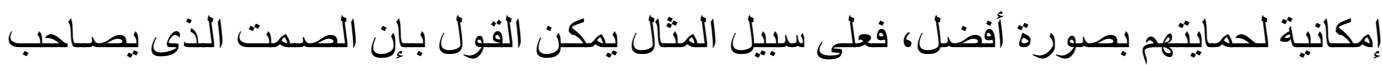
حالات الاستغلال الجنسى للأطفال داخل نطاق الأسرة، أدى على سبيل المنال إلى حماية

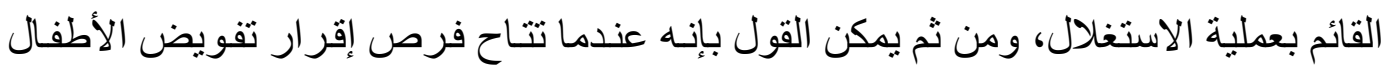

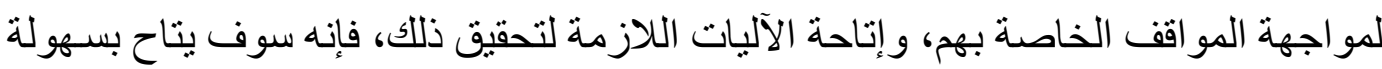

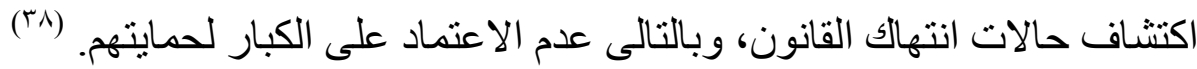
وبالإضافة إلى ماسبق تبرز أهمية المشاركة بالنسبة للطفل فى اتخاذ قرارات إيجابية

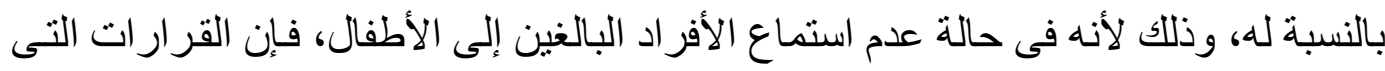

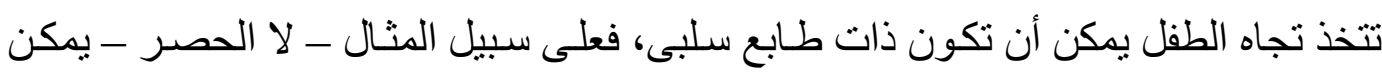

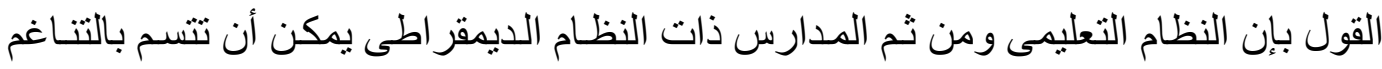

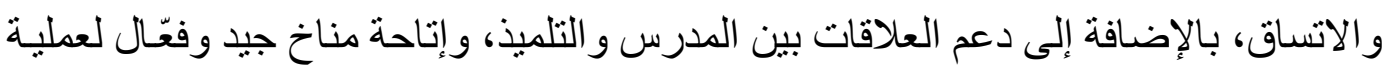

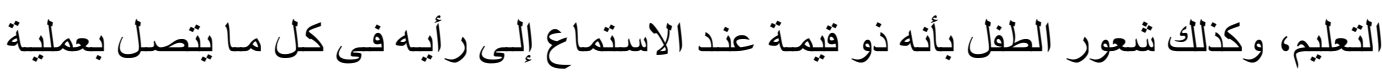

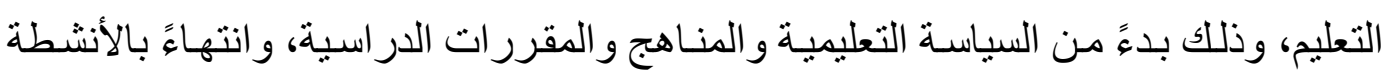

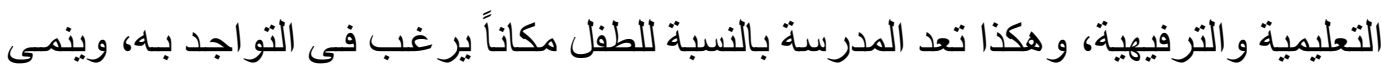

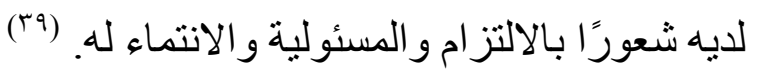

أ: أنماط المشاركة

تتعدد وتتباين أنماط المشاركة بالنسبة للطفل ـ وذلك تبعاً للعمر ، و الخبرة، و القدرات

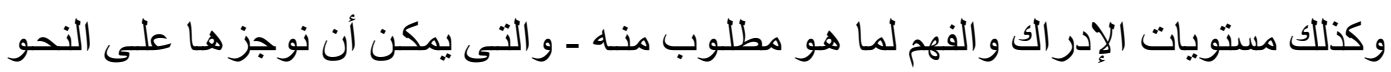
التالى:(•) أ - ألإكراه أو الإجبار Coercion يجسد هذا النمط من المشاركة قيام الأطفال بتنفيذ مطالب الأفر اد البالغين وذلك دون

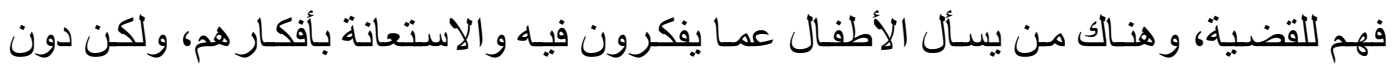

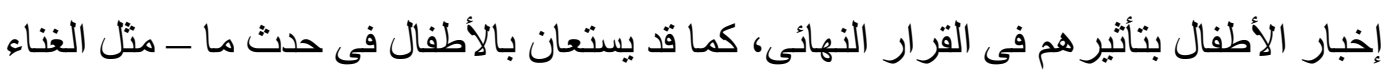

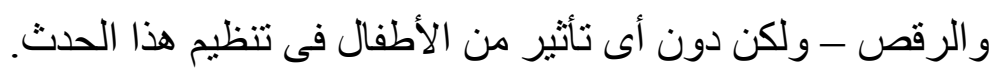




\section{أ ـ ؟ - إخبار الأطفال Informing:}

قد يُعطى للأطفال مهمة محددة، وإخبار هم بالثىى المطلوب تنفيذه.

أ ـ ب ـ العمليات الاستثارية Consultation

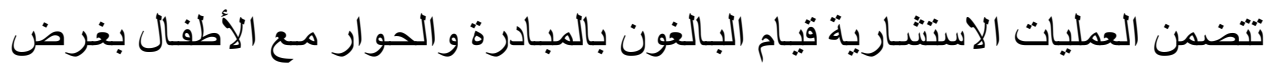

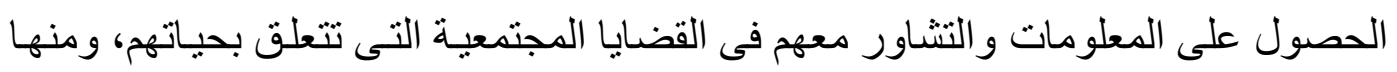

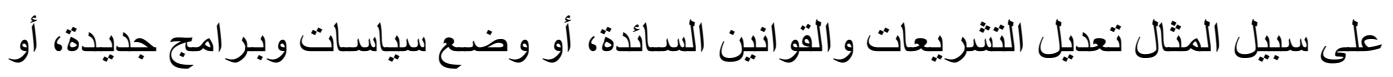
تصميم مشروعات.

أ ـ ـ ـ التعاون والثراكة Collaboration and Partnership:

قد يكون لدى الكبار الأفكار و المبادئ الأولية، ولكن يستعان بالأطفال فى كل مرحلة من مر احل التخطيط و التنفيذ حيث يتمثل الهدف فى تعزيز العملية الديمقر اطية، ومن ثم إناحة

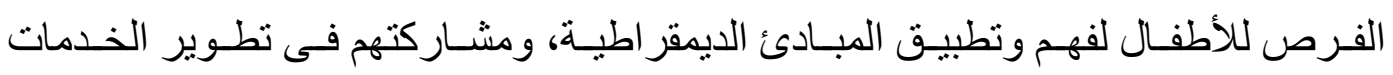
و السياسات الخاصة بهم. أ ـ ـ ـ ـ الدعم الذاتى Self-Advocacy: يتمثنل الهـدف مـن تمكين الأطفـال فـى تحديد الأهداف و المبـادر ات الخاصـة بهم و إمكانية تحقيقها.

ويمكن القول على ضـوء ماسبق بـإن النمطين الأول والثانى لا يجسدان مشـاركة بالمعنى المتعارف عليه، وذللك فى مقابل الأنماط الثلاثة الأخرى، و هذا ما سنركز الاول عليه لانئ لاحقاً عند حديثنا عن النماذج و التجارب التطبيقية لعملية المشاركة بالنسبة للطفل. ب: أسس عملية المشاركة (عجلة المشاركة) هنـالك العديد مـن المفـاهيم و المصطلحات التى تطلق على أسس المشــاركة ومنهـا

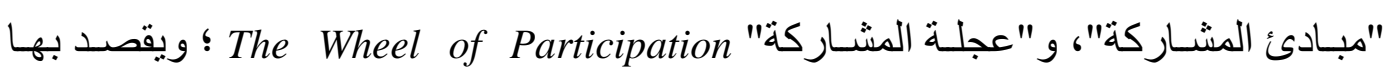

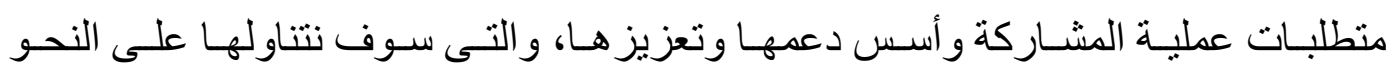
التالى:(1) 


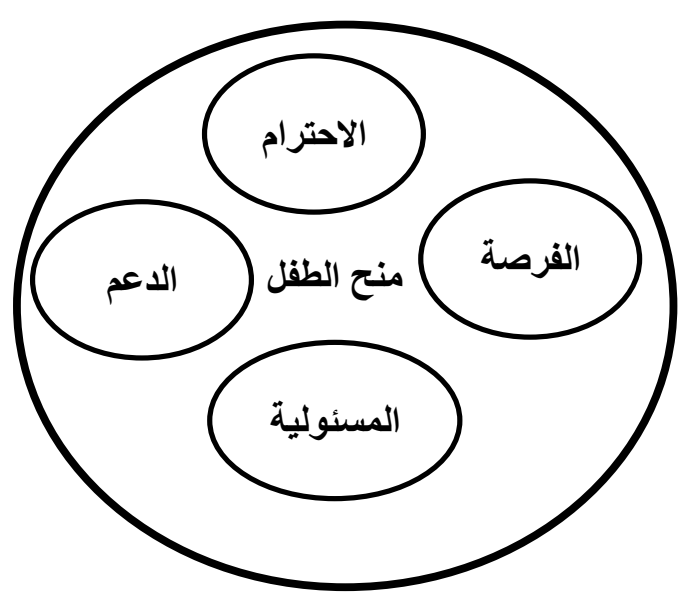

" رسم توضيحى يبين عجلة المشاركة"

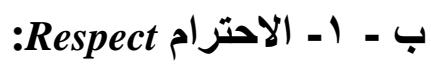

يعد الاحتر ام بمثابة مبدأ أساسى من أجل استكمال عجلة المشاركة ويكون من خـلال الاستماع إلى أفكار الأطفال و آر ائهم، و إعطـائهم المزيـد من الاهتمـام حول مـا يقدمونـه من من تفسـير ات ومبـررات، وكذللك إعطـاء الأطفـال فرصـاً متسـاوية بغض النظـر عـن قدر اتهم ومهار اتهم. كمـا يمثنل مبدأ الاحتر ام النظر إلى الأطفـال باعتبـار هم ذوى قيمـة منكافئة مـع الكبار، و الاعتر اف بـأن مشـاركتهم بمثابـة حق إنسـانى وليس منــة مـن جانب الكبار الذين

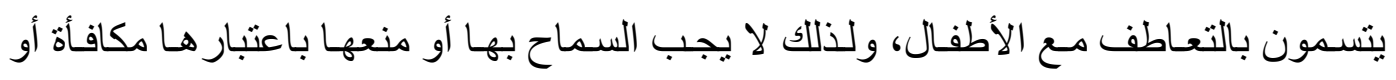

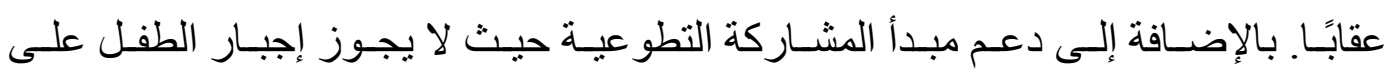
المشار كة.

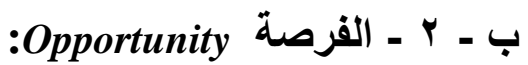

عندما يتمكن الأطفال من التعبير عن آرائهم، سيكون من الضـرورى بالنسبة للكبار إتاحة الفرصـة للأطفال للقبام بذللك، وبعبـارة أخرى تشير المـادة (r I ) إلى ضـرورة التزام الكبار بضمان تمكين الأطفال، أو تشجيعهم للمشاركة بآر ائهم فى الموضـو عات الخاصـة بهم فالأطفال بحاجة إلى فرصة يتعلمون من خلالها حقوقهم وو اجباتهم، و المشـاركة فى عمليات

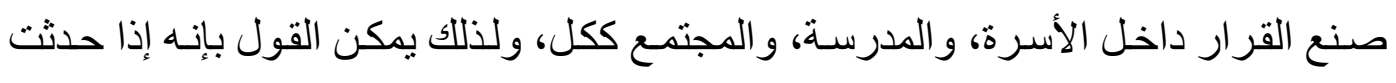
عملية الاستعانة بالأطفال فى اللحظات الأخيرة، فإنه لن تكون هناك فرصة متاحة للتأثير فى النتائج، ولذلك فإنه يجب مشاركة الأطفال بدءاً من المر احل الأولى لأية مبادرة أو مشروع. 
يجب تنشئة الأطفال على تحمل المسئولية واتخاذ القرارات، لأنه لو حملت المسئولية

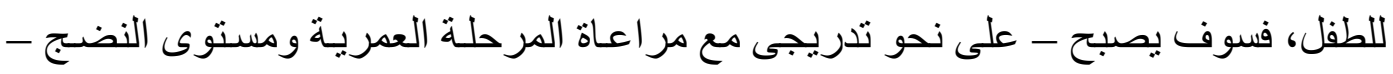

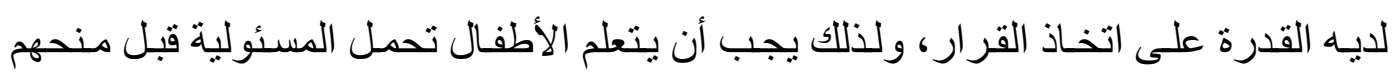
الحقوق الخاصة بهم.

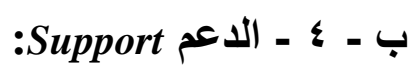

يجب تـوفير الـدعم الكامـل للطفل داخـل المجتمـع وذلـك بـدءاً مـن تـوفير مصـادر

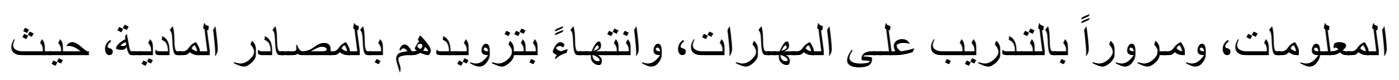

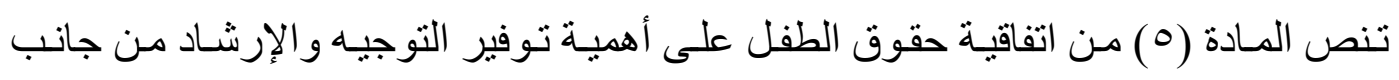
الأسرة و المجتمع عند ممارسة الطفل لحقوقه.

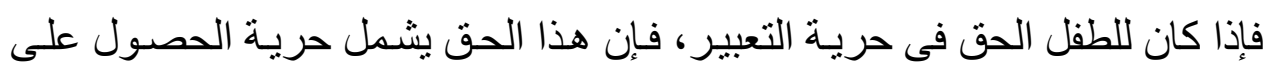

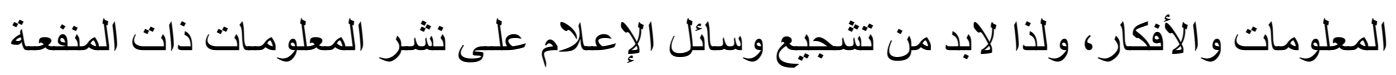

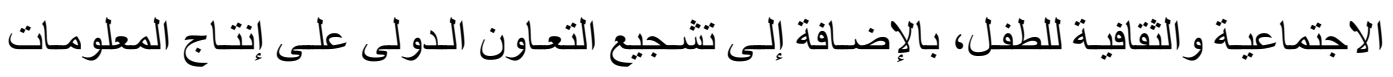

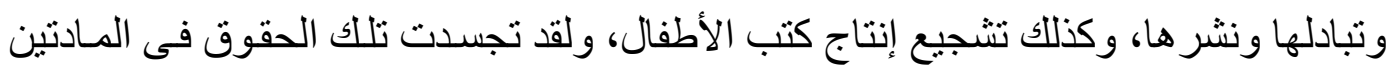

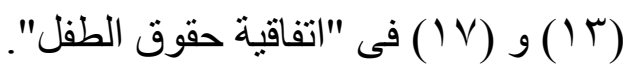

\section{ج : مستويات الإعداد للمشاركة}

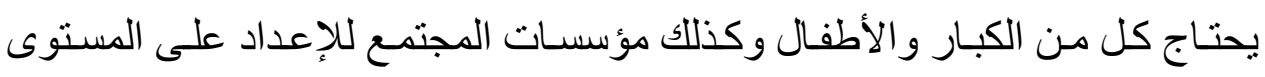

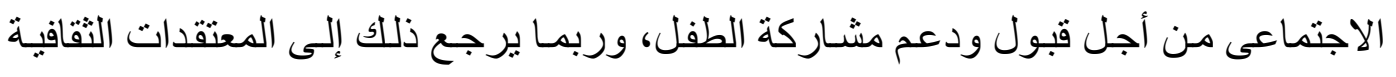

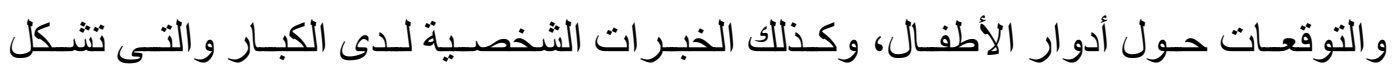

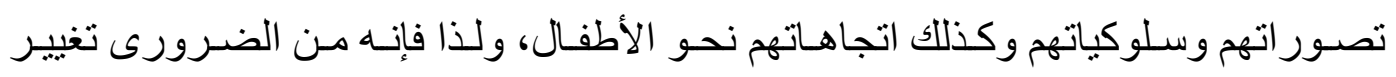

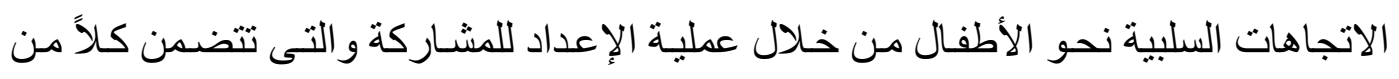

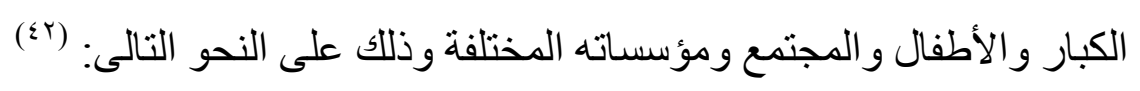

جـ - 1 - إعداد الكبار Prepare Adults:

يجب على الأفر اد الر اغبين فى تسهيل أو تيسير مشاركة الطفل التعرف على قدرات الأطفال من أجل تنمية ذاتهم و عالمهم، كما يجب التغلب على شعور الخوف لديهر عند إعلى إعطاء 
الفرصة لهم ومنحهم المسئولية ، ومن ثم تتمثل الطرق الملائمة لإعداد الكبار لمشاركة الطفل

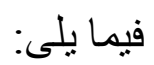

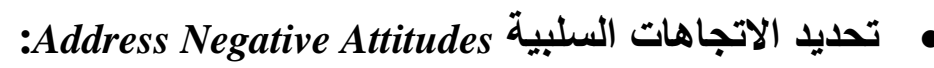

يجب تحديد الاتجاهات السلبية للى الكبار نحو تصور اتهم حول الطفل وتغيير ها،

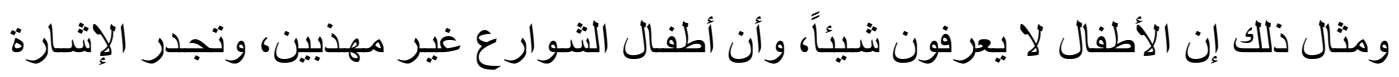

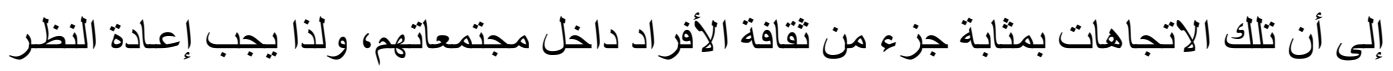

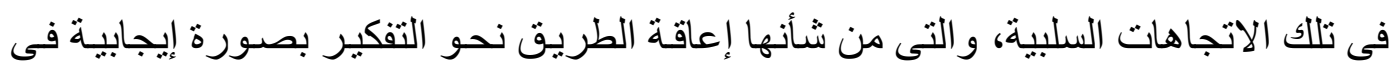
قدر ات الأطفال ومهار اتهم و التى يمكن الاستفادة منها فى المجتمع. • • تقدير الحالات الفردية Appreciate the Individual Cases:

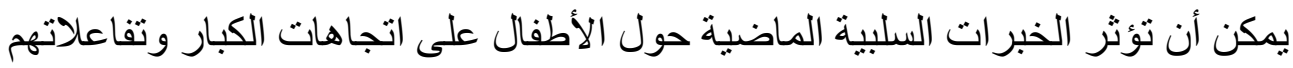

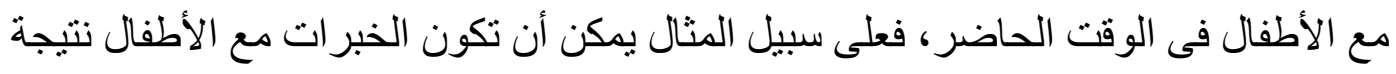

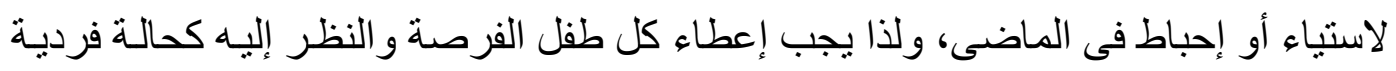

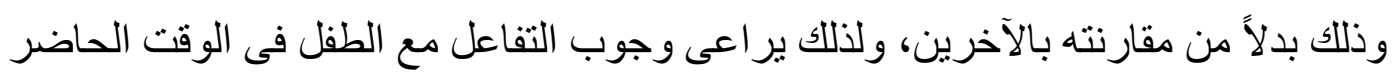
دون التأثر بالخبرات السابقة فى الماضى مع الأطفال.

•Focus on Strengths Points التركيز على نقاط القوة

يمكن القول بإن أنسب طريقة لإعداد الكبار لدعم مشـاركة الطفل تتمثل فى تنمية

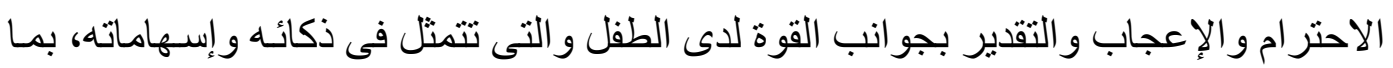

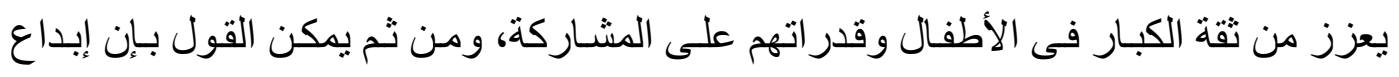
Achievement والأطفال سوف يعزز ثقة الكبار نحو الأطفال. Creativity

\section{ج - ץ - - إعداد الأطفال Prepare the Children:}

تحتاج المشاركة إلى دعم الطفل وتنمية قدر اته للتغلب على أفكاره و آر ائه ومشـاعره

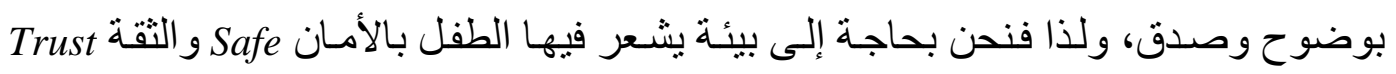

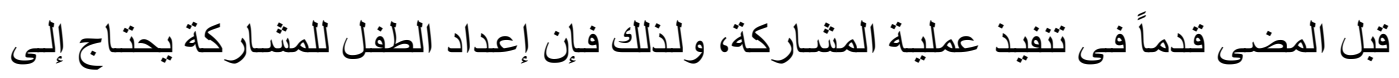
مايلى: 


\section{:Develop Positive Relationships تنمية علاقات إيجابية}

إن تنمية العلاقات الإيجابية و التى يغلب عليها طابع الثقة بين الأطفال و الكبار إنمـا تعد مطلبًا حقيقيًا و أساسيَّا للمشاركة الجادة و الفعالة من خلال التشجيع على الاتصـال المباثـر بالإضافة إلى قضاء الوقت فى تنمية صداقات و علاقات إيجابية مـع الأطفال، وذلك بدءًا من قضـاء الوقت فى ألعـاب التسلية والترفيه، و انتهاءً بممارسـة أنشطة تسـح بالتفاعل النشط، حيث يمكن القول بـإن قضـاء الوقت فى إجر اء الحوار ات والمناقتـات يمكن الطرفين من توطيد العلاقات، ومعرفة بعضهم البعض.

\section{Promote Understanding تعزيز الفهم •}

يمكن القول بإنه لا يستطيع الأطفال الاستجابة للقضـايا المجتمعيـة مـا لم يكن لديهم الفرصة للإدر الك و الفهم و التعلم، ولذا يمكن القول بـإن الجهل بعد من أبرز العوائق التى قد تقف أمام نجاح عملية المشاركة، بينما تعزز المعرفة عمليـة المشـاركة، ولذا فـلا بـ من نقل Peer Education المعلومات للأطفال من خلال الحوار وحلقات النقاش، كما بعد تعليم القرناء - و الذى نقصد به الحوار ات فيما بين الأطفال - بمثابة طريقة فعالة للأطفال لاستقبال وتبادل المعلومات ووجهات النظر حول القضايا الاجتماعية.

ج - ب - إعداد المجتمع ومؤسساته:

قد تثكل الثقافة السائدة داخل المجتمع حاجز اً أمام مشاركة الطفل، ولذا يمكن القول بإن هناك طرقاً فعالة من شأنها تعزيز الوعى بـالمجتمع حول أهمبـة المشـاركة؛ ومنهـا دعوة قادة المجتمـع، و الآبـاء و المدرسين، و أعضـاء المجتمع إلى تقديم أفعال وأنشطة تحققت من هن خلال الأطفال، بالإضـافة إلى دعم مشاركة الأطفال فى أنشطة المجتمع المختلفة وبـالأخص المص القضـايا المرتبطــة بهـم ومنهـا علـى سـبيل المثــال الخـدمات التعليميـة و الصـحية، وكذللك

$$
\text { مشرو عات حماية البيئة من أخطار التلوث. }
$$

كما يتضمن نشاط إعداد مؤسسات المجتمع لدعم وتعزيز مشاركة الطفل فيمـا يعرف "بينـاء القدر ات" Capacity Building ؛ وهى عبـارة عـن عمليـة تـدخل خـارجى لتحسين

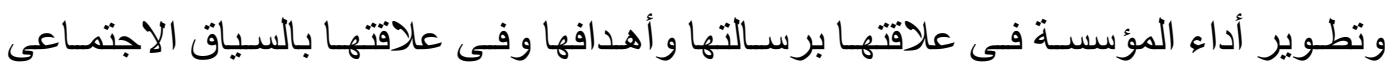
و الاقتصادى و الثقافى الذى توجد فيه، وكذللك توظيف مو اردها بما يحقق لها الاستدامة وذلك

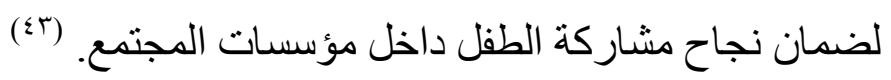




\section{د: دماذج من تجارب عالمية لمشاركة الأطفال}

يُخصَّص هذا المحور لإلقاء الضوء على نمـاذج من تجارب فى مجال مشـاركة

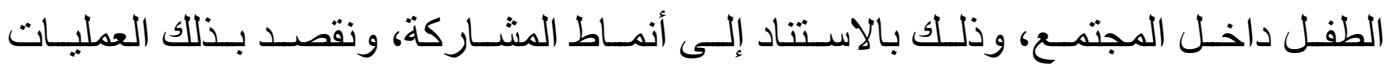

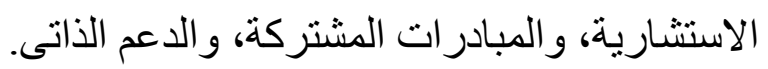

\section{لـ - 1 ـ العمليات الاستثارية: Consultative Processes}

تعد العمليات الاستثـارية بمثابة نمط من المشـاركة يسعى الكبار من خلالها إلى الكى

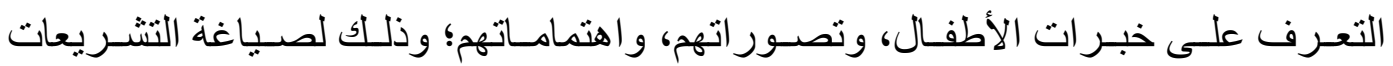

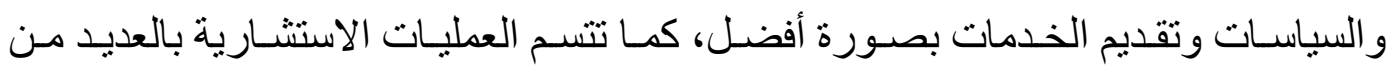

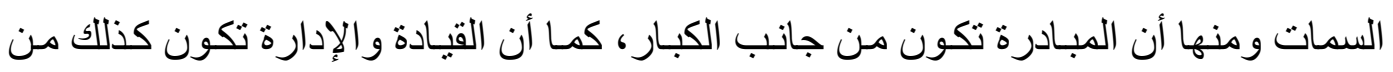

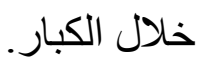

ومن الأمثلة الخاصة بهذا النمط من المشاركة العمليات الاستشارية للثبكة الأوروبية Euronet

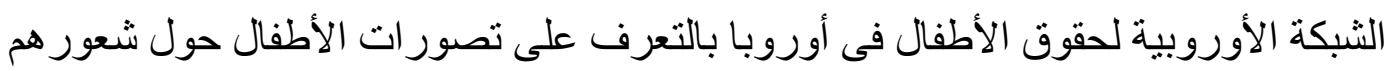

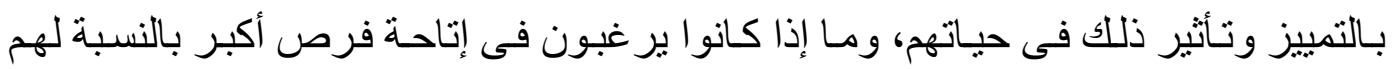

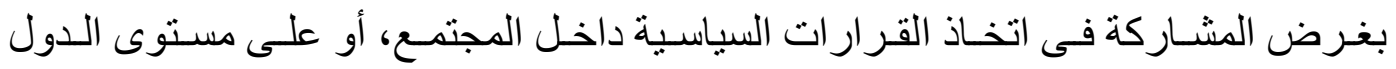

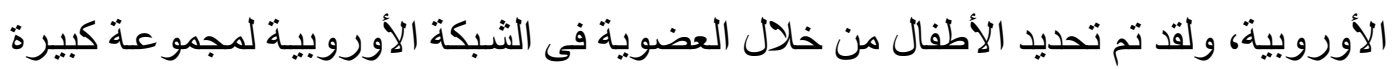

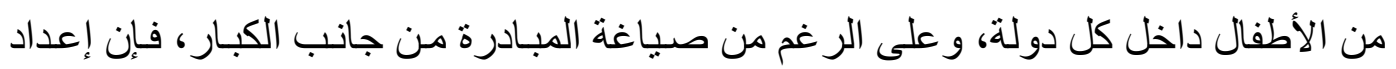

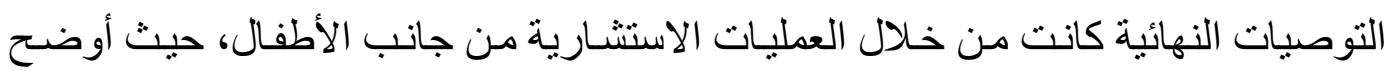

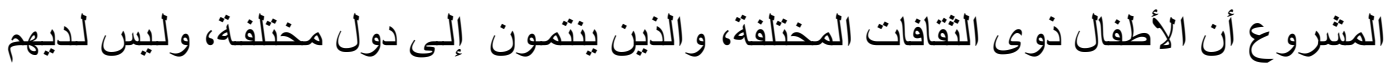
لغة مشتركة كانو ا قادرين على التعاون و العمل بصورة فعالة تجاه الهدف المشترك، حيث

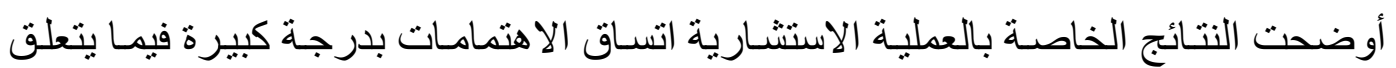

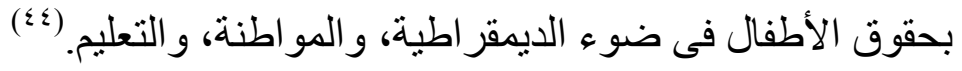
دـ - بـ المبادرات المشتركة: تتيح المبادرات المشتركة ـ كما سبق الإثشارة من قبل ـ فرصًا أكبر من أجل المشـاركة

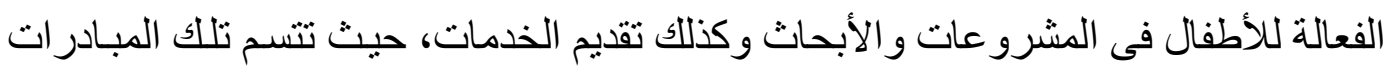
بإعطاء الفرصة للكبار لاتخاذ المبادرة للتعاون مع الأطفال، كما تتضمن خلق البناءات التى لتص

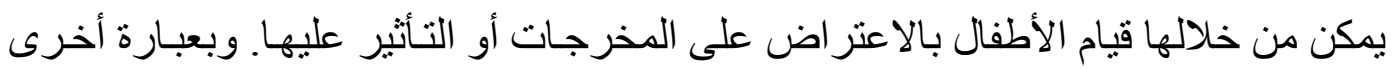


على الرغم من أن العهل يبدأ من خـلال الكبـار، فإنـه يتضـمن التعـاون مـع الأطفال، حيث

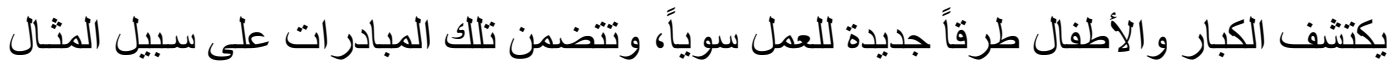

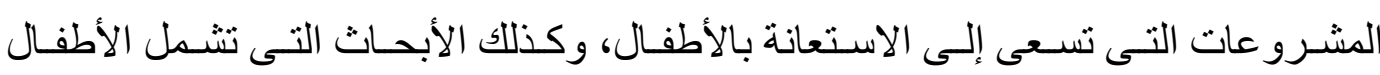

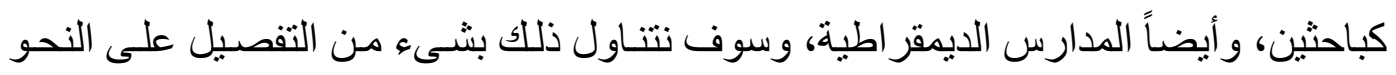
التالى: (£0)

إن الشرو عات التى تسعى إلى الاستعانة بالأطفال باعتبار هم شركاء تتنـاول مجالات

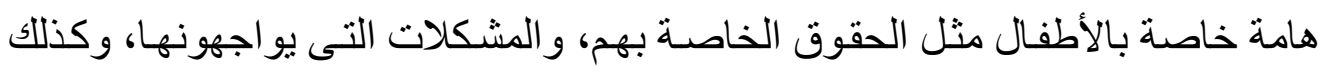

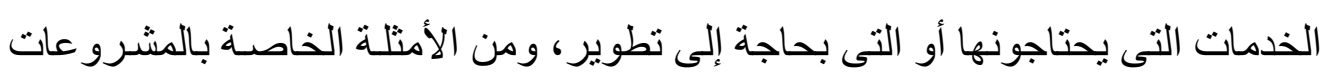

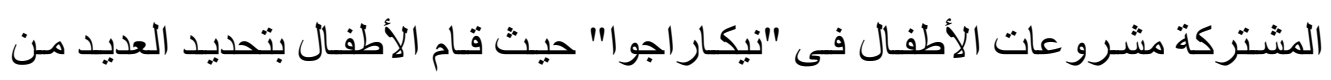

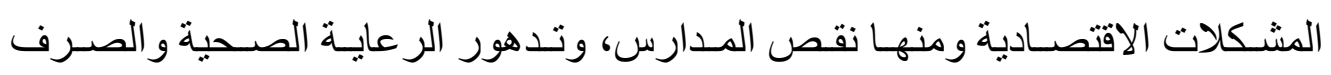

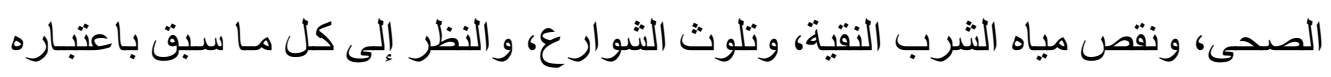

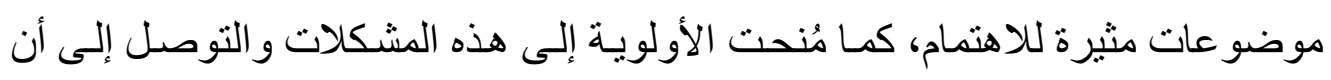

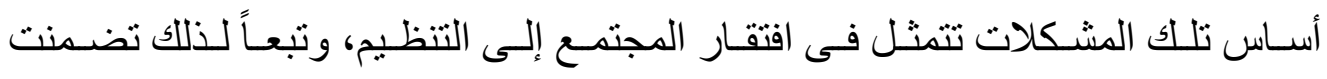

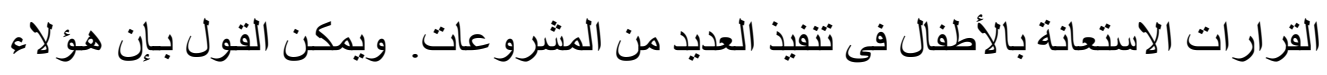

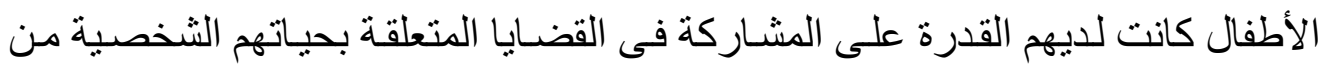
خلال عدد من المستويات وذلك بدءاً من قدرتهم على تحديد مجموعة من العو امل السلبية

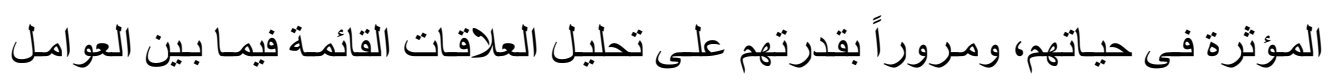

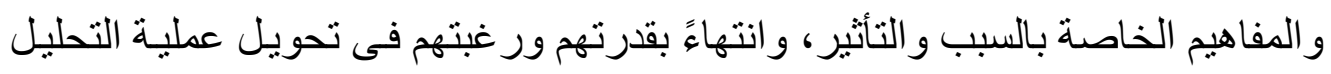
إلى إجر اء عملى بغرض الارتقاء بمستوى البيئة المحلية التى يعيثون فيها. تتضمن الأبحاث التى تثمل الأطفال كباحثين تمكين الأطفال من تحديد الأجندة البحثية

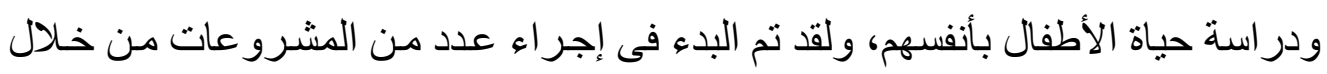

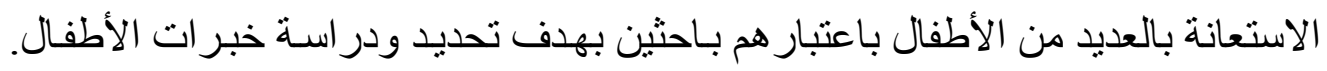
ومن الأمتلة على ذلك ما يعرف باسم "العدالة للأطفال" حيث بدأت مبادرة "حماية أطفال

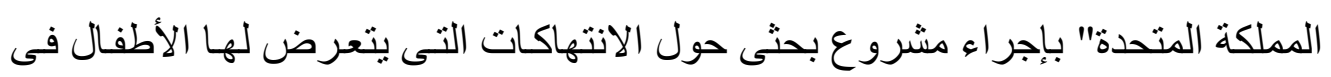

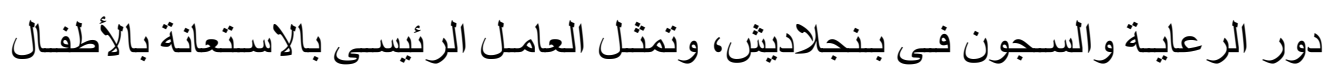

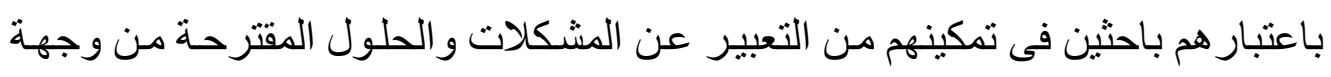

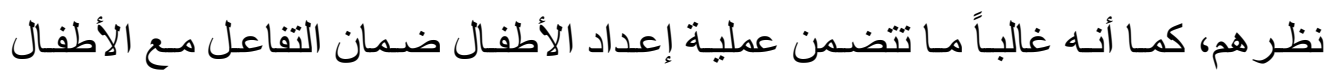

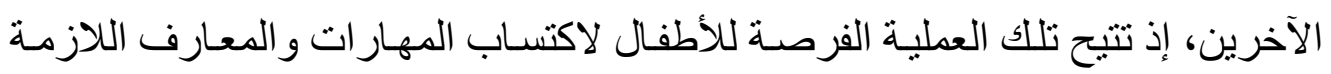


وكذللك الثقة بالنفس، بالإضافة إلى إناحة التدريب و الدعم للأطفال وتطوير إطار أخلاقى

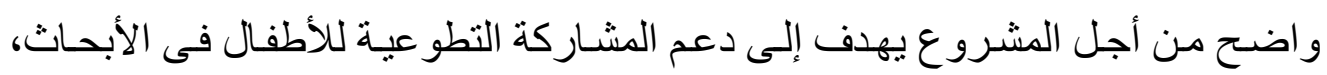

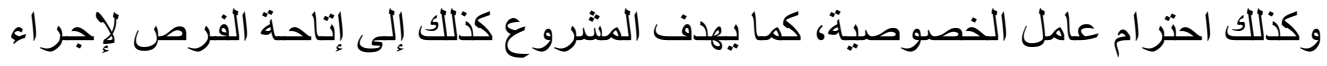

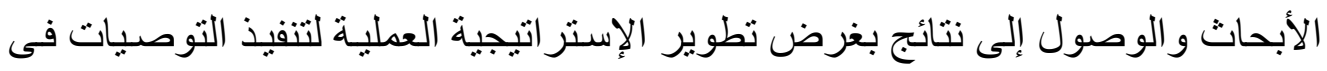

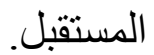

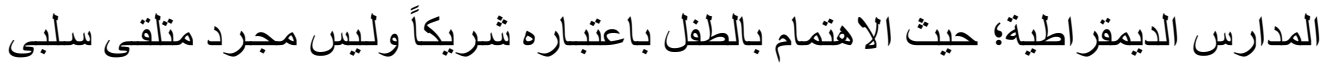

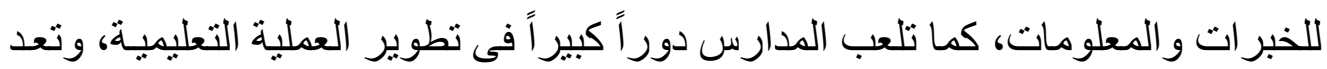

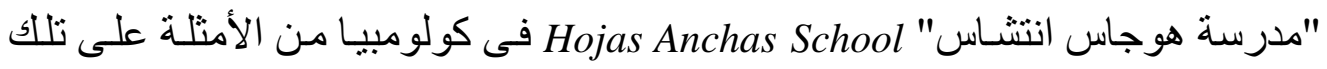

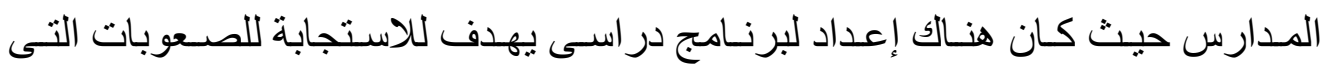

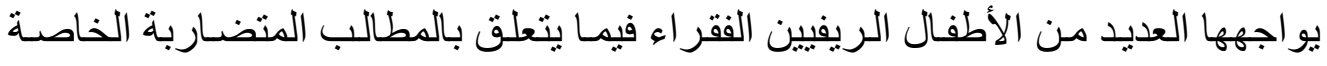

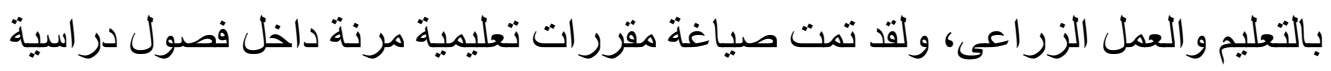

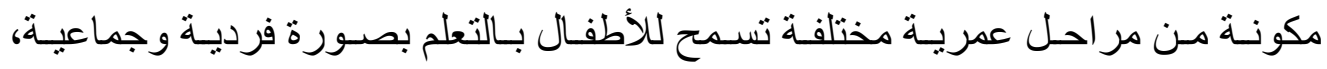

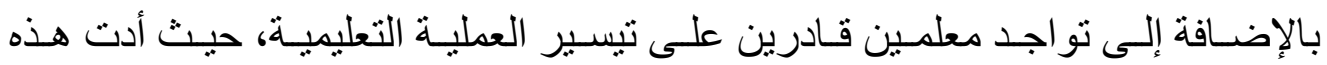
المدارس إلى تطوير كيانات تمكن الأطفال من العمل فى إطلار مجتمع ديمقر اطلى يتسم

يعد الدعم الذاتى بمثابة عملية تهدف لتمكين الأطفال من اتخاذ الإجر اءات اللازمـة لتحديد الموضو عات الهامة من جانبهم وبأنفسه، كما يتمثل الدور الخاص بالكبار فى عملية التيسير وليس القيادة To Facilitate not to Lead ، بالإضافة إلى التحكم فى تلك العملية من

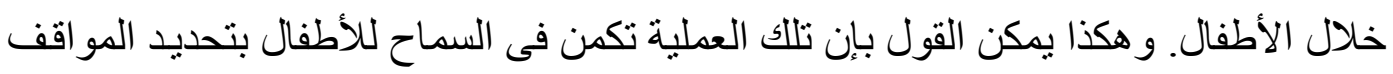

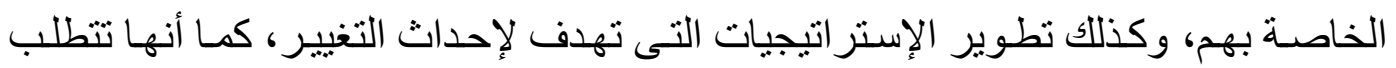

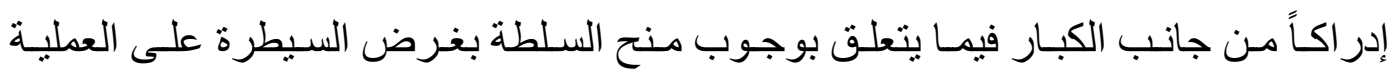
و النتائج لصالح العلاقات المشتركة مع الأطفال، و هكذا يمكن القول بإن دور الكبار يكمن في فئي إنهم مستشارون و إداريون وقائمون بتقديم الدعم وجمع الأمو ال. الـال.

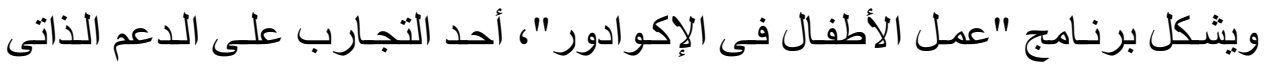

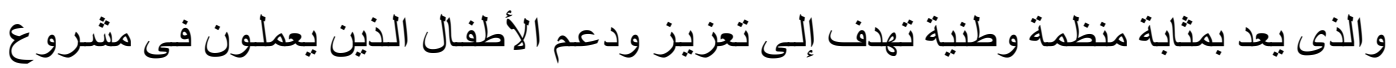

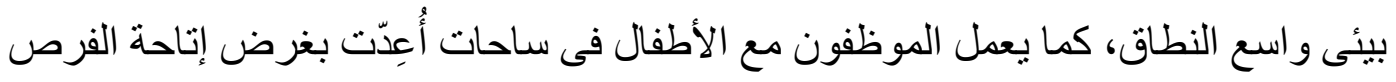


للأطفال الذين يعيشون فى مناطق حضرية فقيرة بغرض تعلم كيفية الدفاع عن حقوقهم. وفى التى

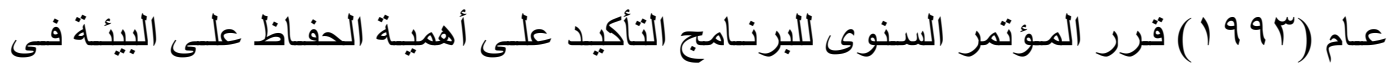

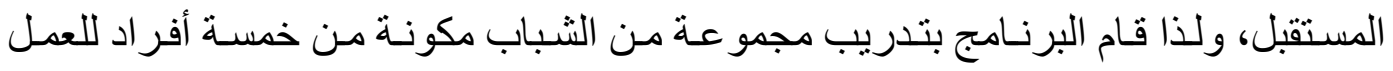

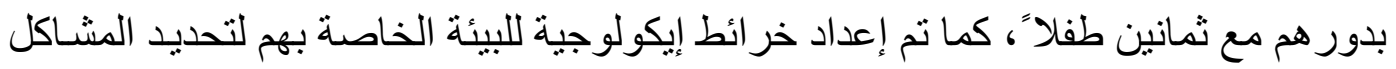

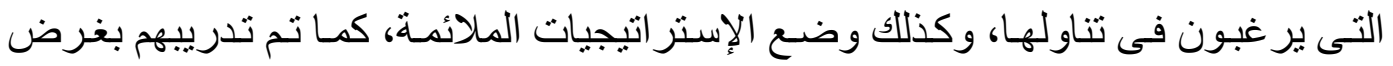

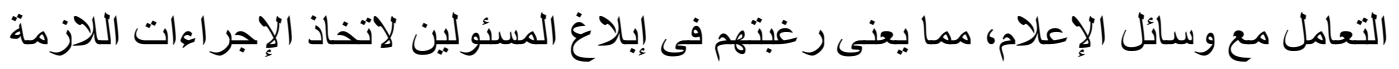

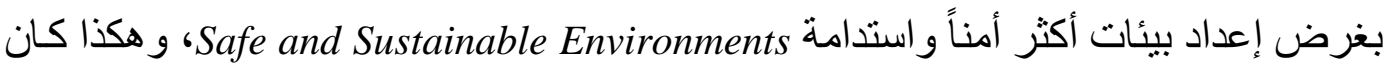

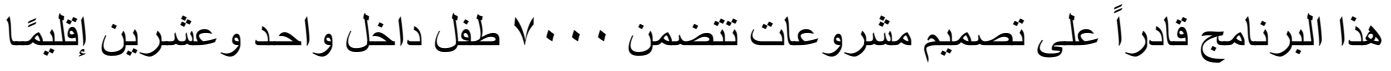

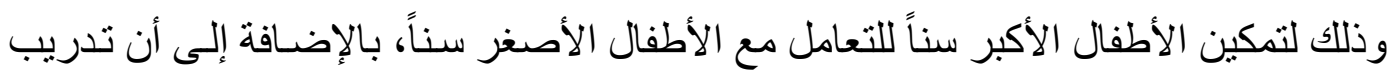

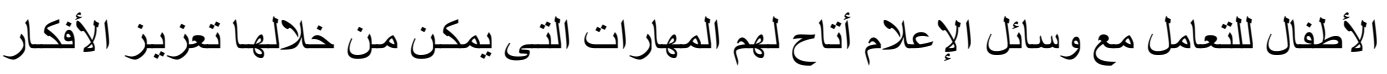

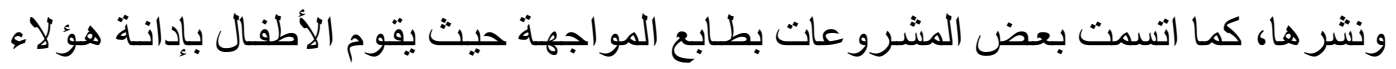

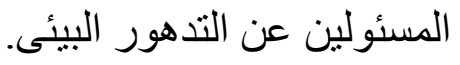

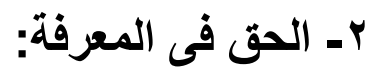

يرتبط الحق فى المعرفة بحق الطفل فى حريـة التعبير حيث تثبر المسادة (r ( ) من

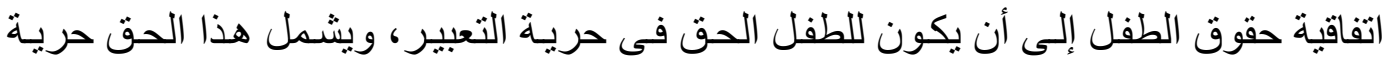
طلب جميع أنواع المعلومات، والأفكار وتلقيها وإذاعنها دون أى اعتبار للحدود سواء لـاء بالقول

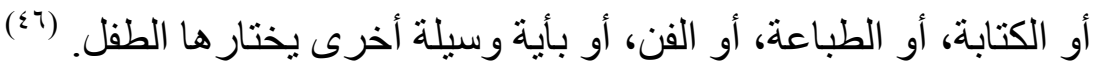

ويتجسد الحق فى المعرفة بالنسبة للأطفال على سبيل المثال ـ لا الحصر - داخل

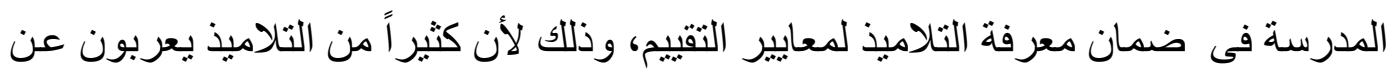

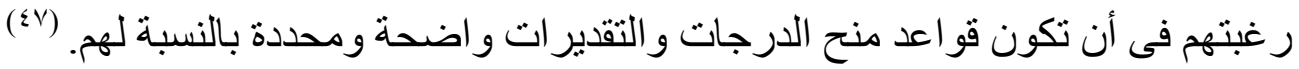

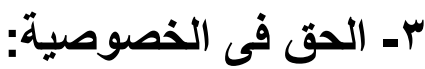

تشـير الدـادة (7 1 ) مـن اتفاقيـة حقوق الطفل إلى أنسه لا يجوز أن يتعرض الطفل

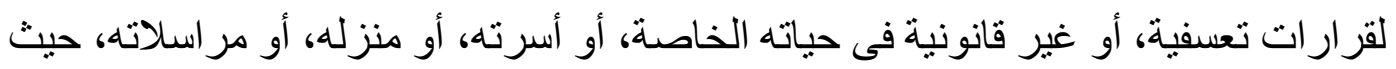
يحق للطفل أن يحميه القانون من مثل هذا التعرض، أو المساس بأموره الخاصة. و على سبيل المثنال فإن بعض الممارسـات التربويـة قد تؤدى إلى تجاوز الحدود

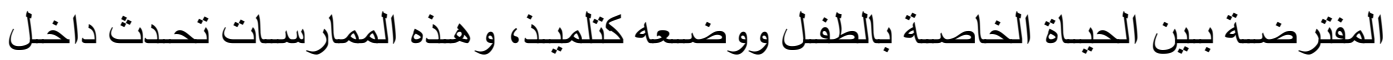
المدرسة دون الأخذ فى الاعتبار ما يمكن أن يشعر به التلاميذ بسبهها أمام زملائهم. فالتلاميذ 


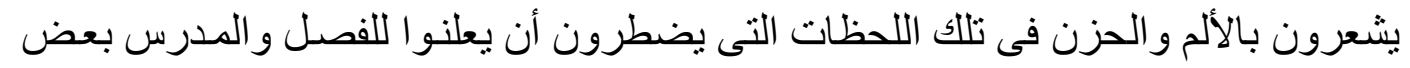

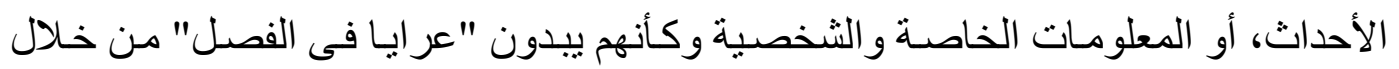

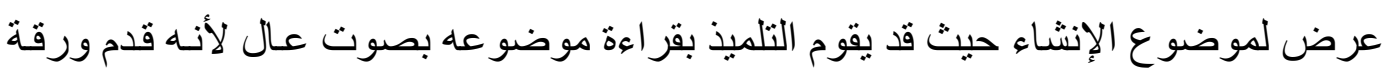

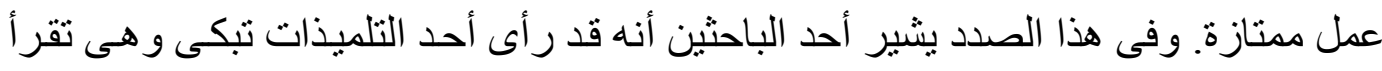

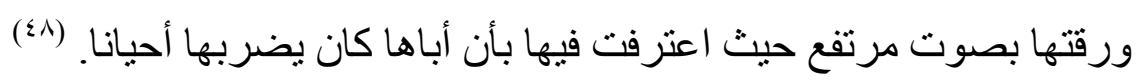

ثانياً: القيم الإنسانية:

يتضمن تعليم المو اطنة مجمو عة من القيم الإنسانية ومنها على سبيل المثال التعاون

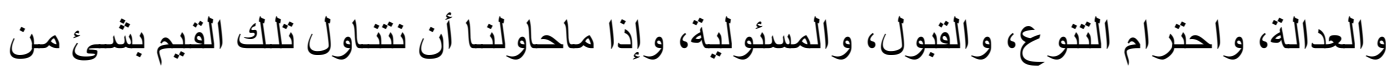

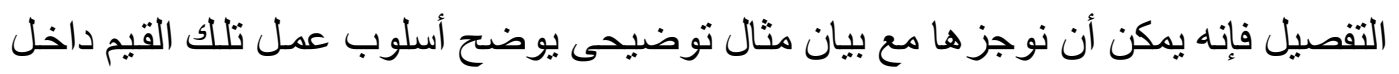

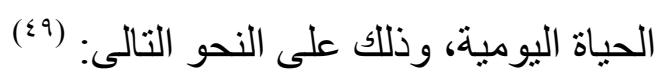

\begin{tabular}{|c|c|c|}
\hline المثُال & التعريف & القيمة \\
\hline 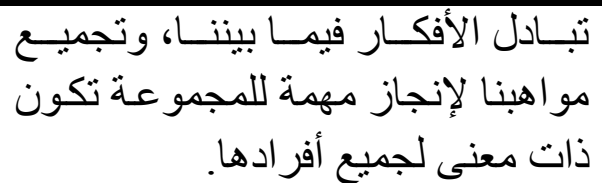 & هدف مشترك إن هو العمل معـاً لتحقيقق & التعاون \\
\hline 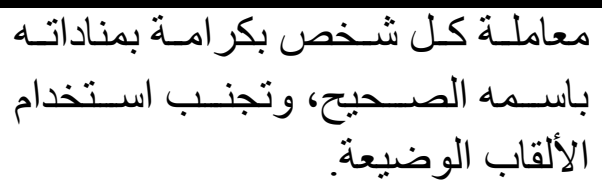 & الإن يُعامل الاحتر امة أن كل شخص وفى سياق حقوق & الاحترام \\
\hline 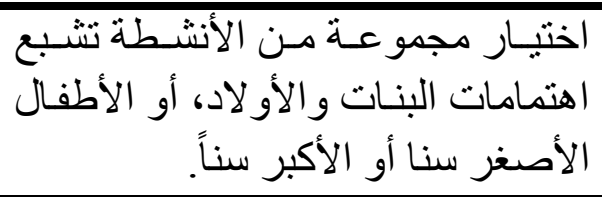 & 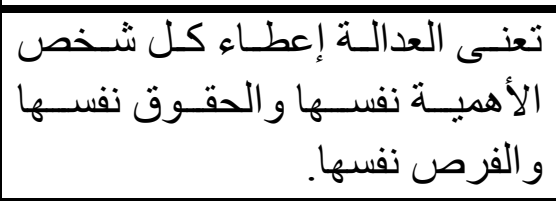 & العدالة \\
\hline 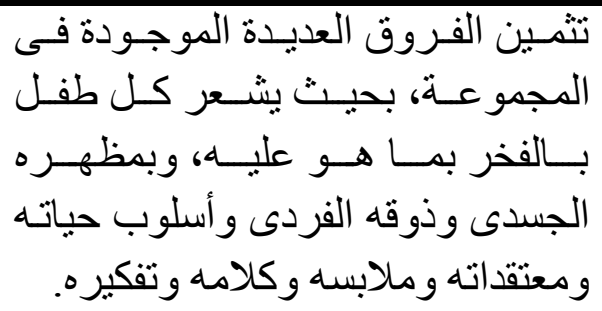 & 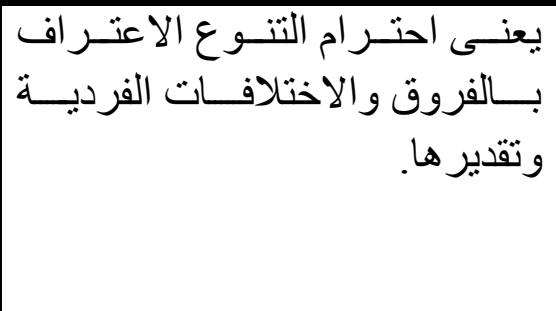 & 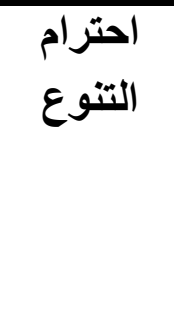 \\
\hline 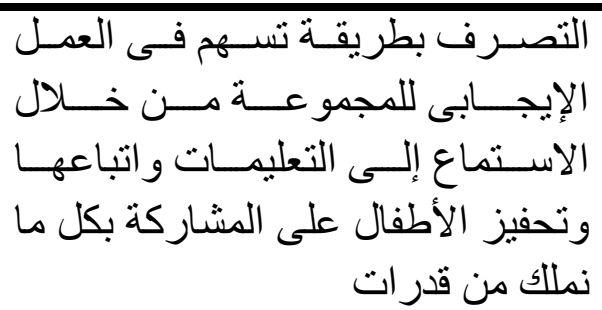 & 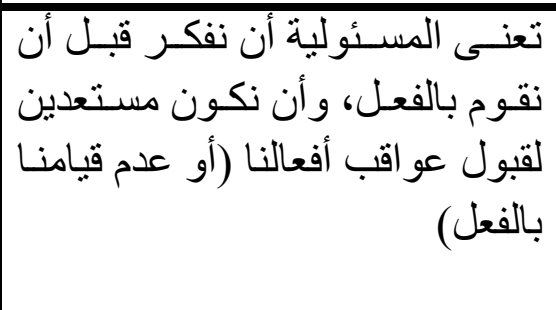 & المسئولية \\
\hline
\end{tabular}




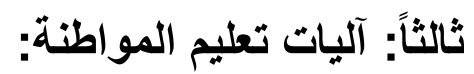

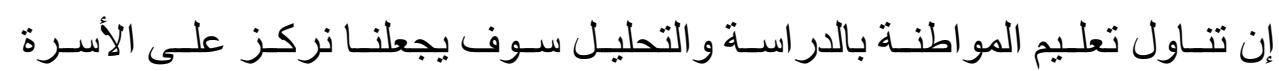

و الددرسة للتعرف على دور هما فى عملية تعليم المو اطنة بالنسبة للأطفال.

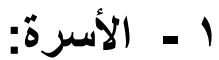

يعد المجال الأسرى بمثابة المجال الأول الذى برتاده الطفل بعد و لادته، ومن خلال

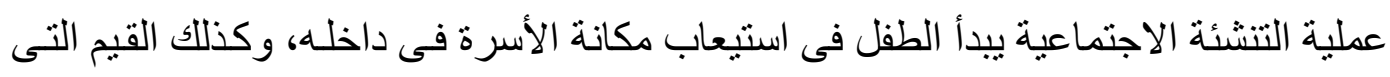

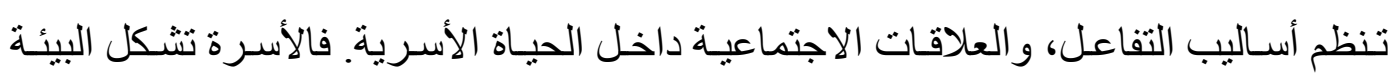

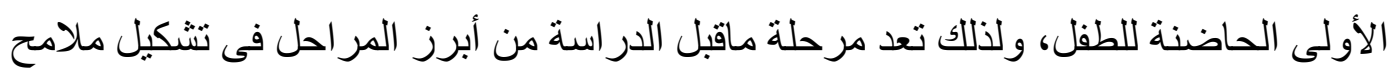

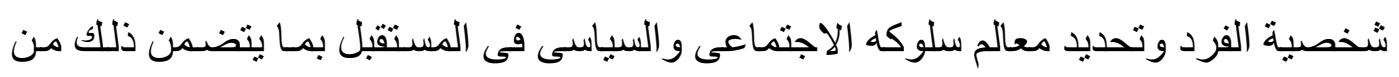

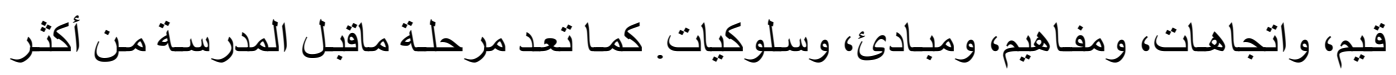

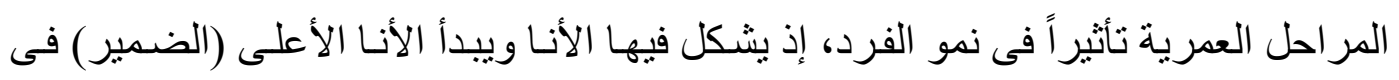

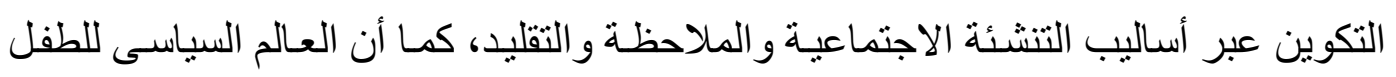

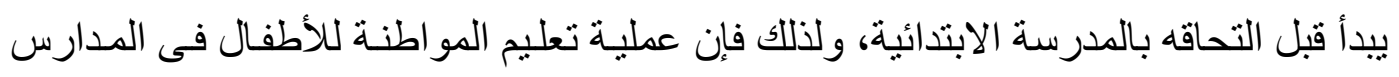

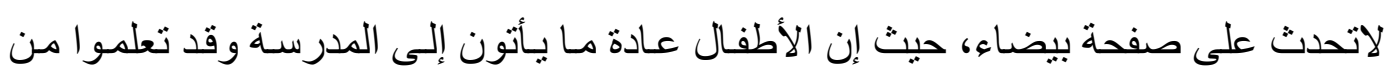

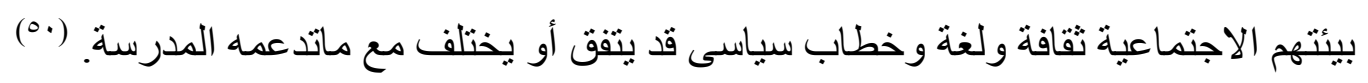
ويمكن القول إن من أبرز العو امل الأسرية المؤثرة فى الحياة الدنية اللاحقة للطفل

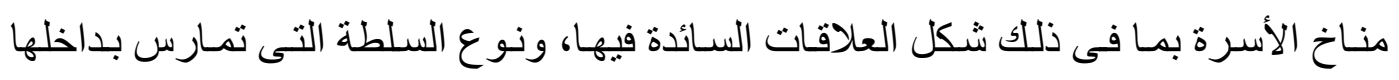

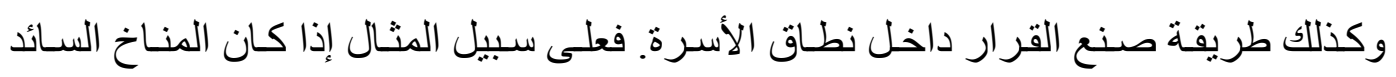

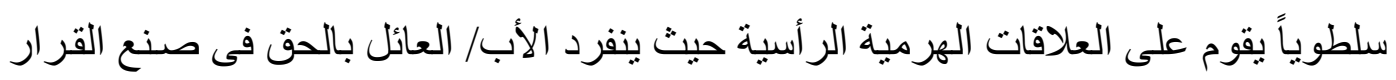

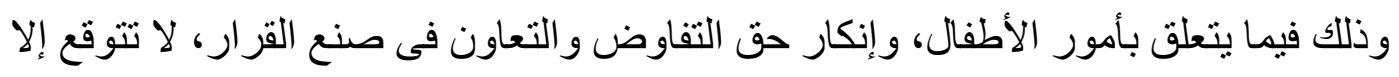

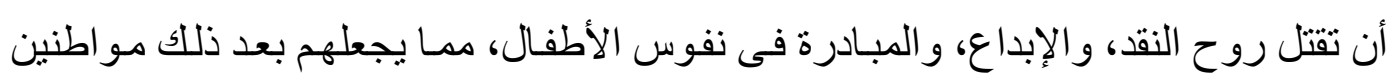

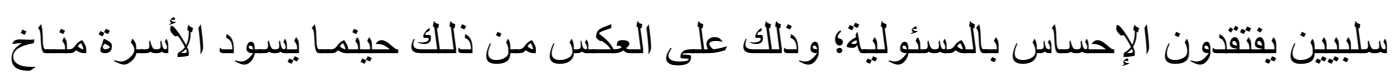

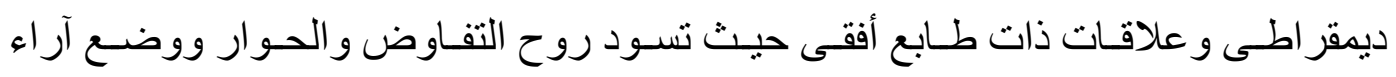

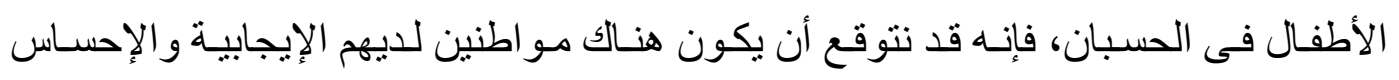

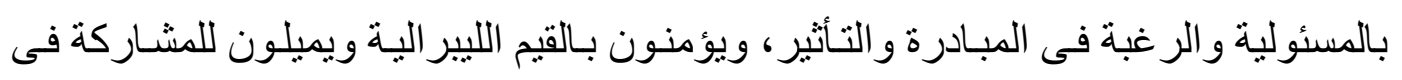

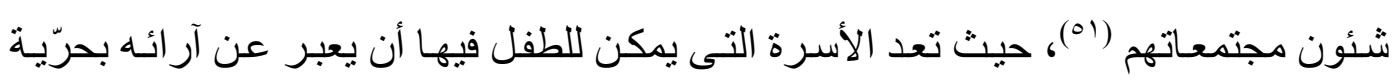

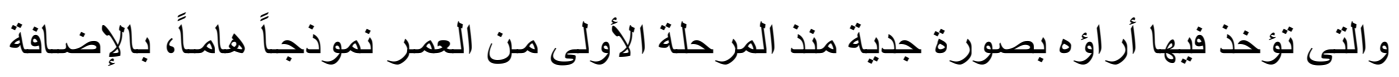
إلى دعم حق الطفل فى الاستماع إليه فى المجتمع على نطاق واسع. 


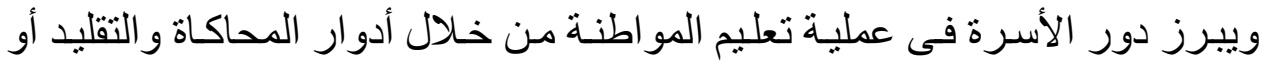
القدوة والتى يكون لها دور فى تبنى القيم و الميول و الاتجاهات المدنية والسياسية حيث يشكل الو الدين وأعضاء الأسرة أبرز النماذج التى يتعرض لها الأطفال ، كمـا أنه في إطـار الأسرة

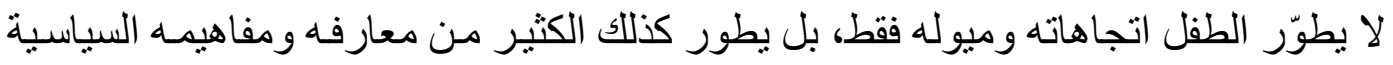

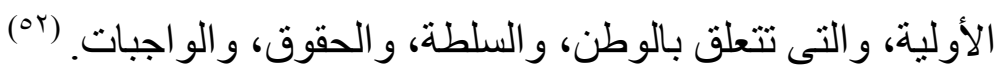
و إذا تأمنا دور الأسرة ومساهمتها فى تعميق انتماء أطفالها إلى الوطن وارتباطهم بـهـ. فسوف نجد بداية أن الأسرة المنماسكة و المستقرة هى التى تستطيع القيام بهذا الدور، فالأسرة تتولى تجميل الوطن فى عيون أطفالها، وحتى تحقق الأسرة هدفها الأصيل فى تعديق انتماء

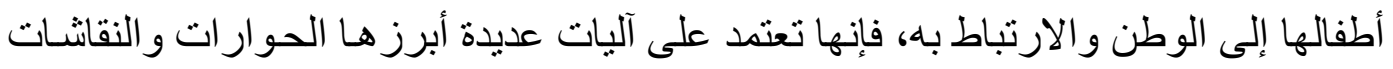
العائلية التى تدور حول القضايا الوطنية، والأحداث التاريخية، وكذلك اصطحاب الأطفال

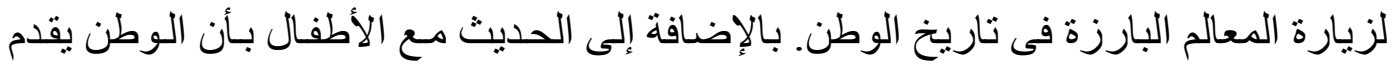

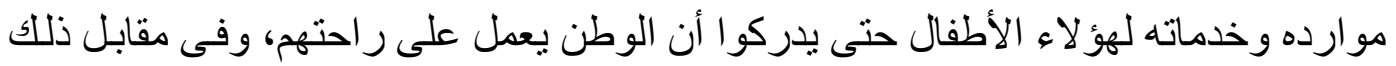

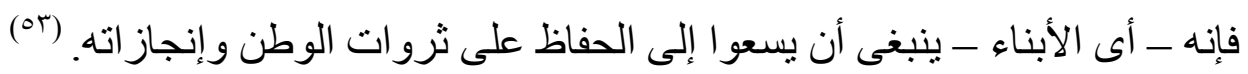
كما يعد المجال السياسى من المجالات المحوريـة التى يمكن أن تلعب الأسرة دوراً

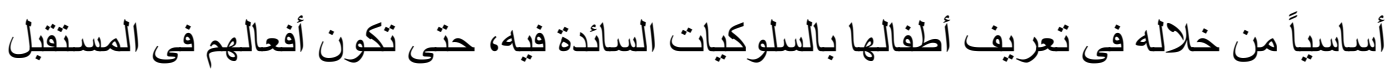

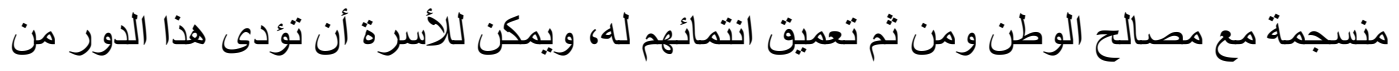

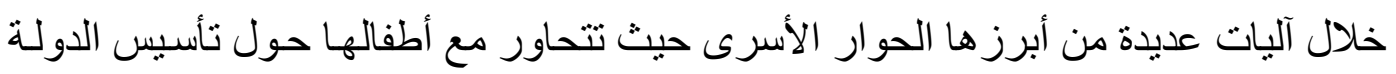

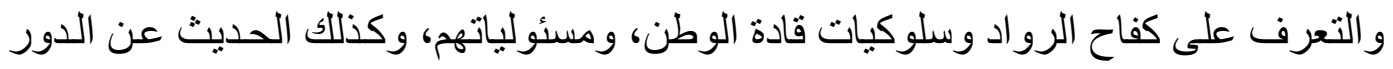

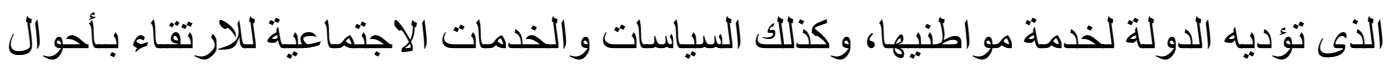

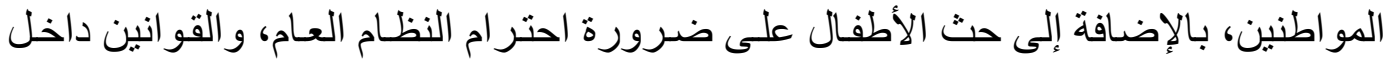

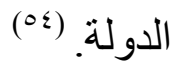

وإجمالاً لما سبق يؤكد جون باتريك أن الو الدين هما المعلم الأكثر تأثير اً فى القيم

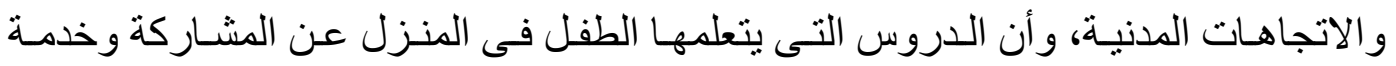

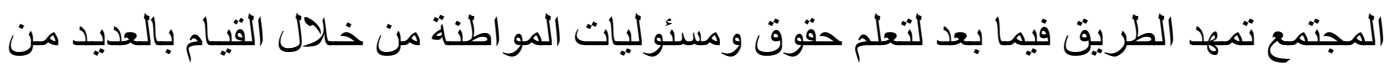
الأنشطة فى المنزل ومنها على سبيل المثال: (00)

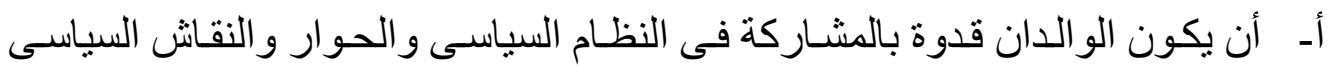
وكنلك التطوع فى مشرو عات خدمة المجتمع. 
بـ إظهار الاهتمـام بالثـئون السياسية من خـلال متابعة ومناقثـة الأحداث والأخبـار

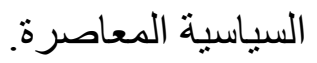

جـ ـ نقل وتعزيـز القيم المدنيـة الديمقر اطيـة مـن خـلال المناقتشـات و السـلوك المثــالى و القو اعد العادلة داخل الأسرة. دـ توفير مصادر التعليم المدنى للأطفال فى المنزل مثل الكتب والجر ائد. هـ ــ تشجيع الأبناء على المشاركة فى أنشطة خدمة المجتمع.

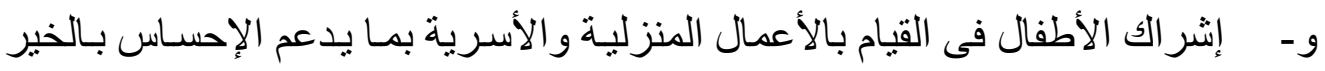

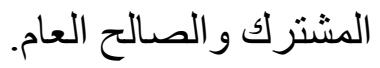
r - 2 - التعليم / المدرسة:

يعد التعليم أحد العناصر الأساسية فى عملية التنشئة الاجتماعيـة للأطفال، ويقصد

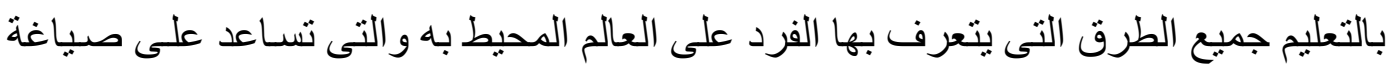

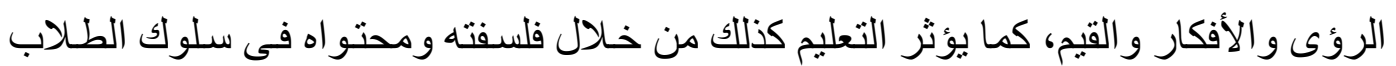

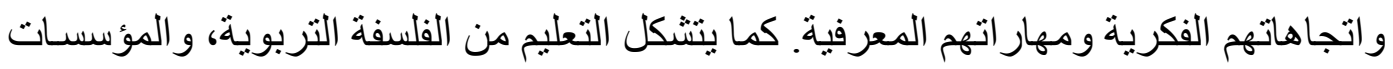

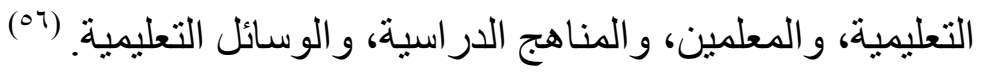
ويمكن القول إن أهية المؤسسات التربوية تبرز فى أنها تمثل الخبرة الأولى للطفل

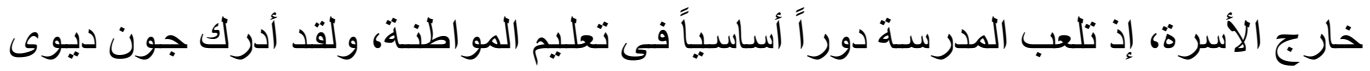

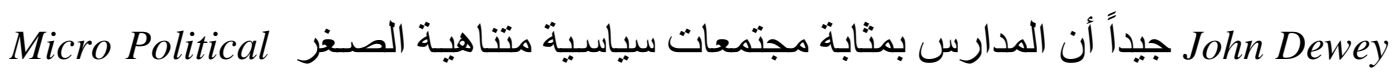

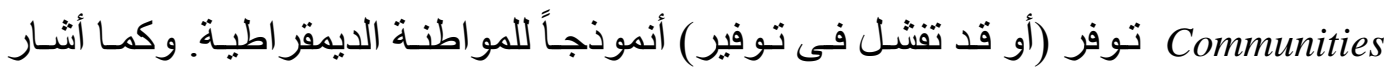

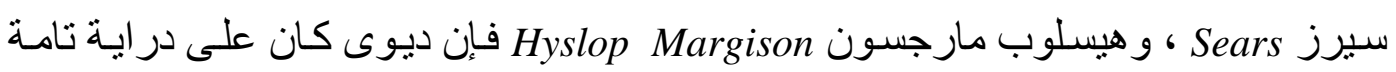

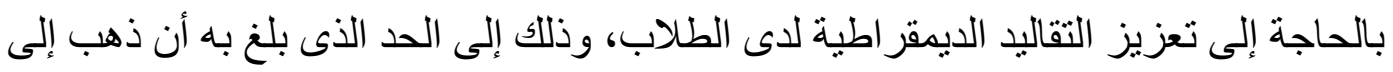

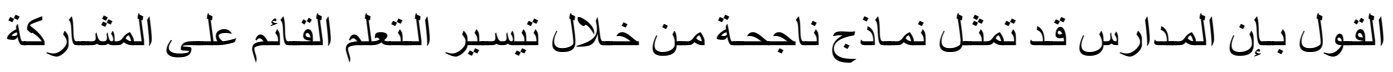

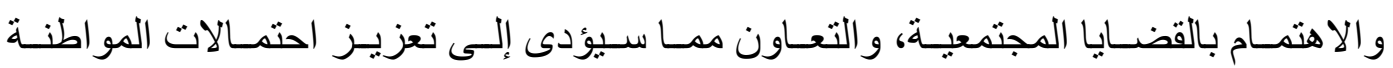

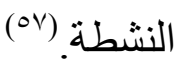

وتبدو أهمية العلاقة بين المدرسة والمو اطنة من خلال القول بإن "انعدام الديمقر اطية

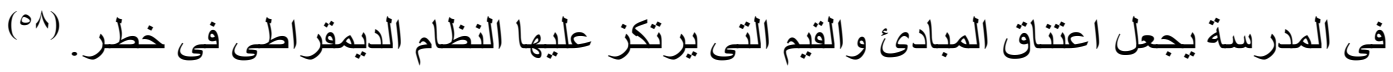

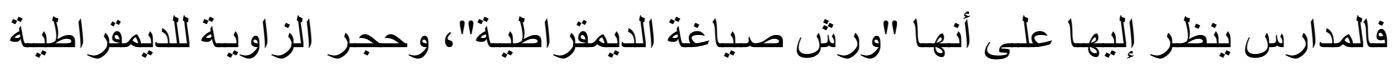

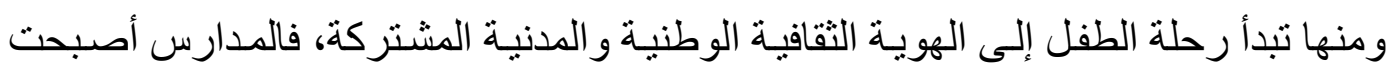


المؤسسـات العامـة التـى تتحمـل تلك المسئولية، ويـرى بـاربر Barber أن الرسـالة المدنيـة

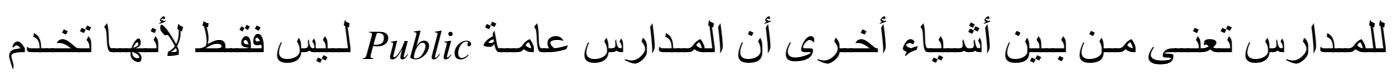

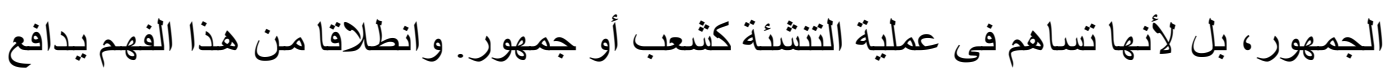

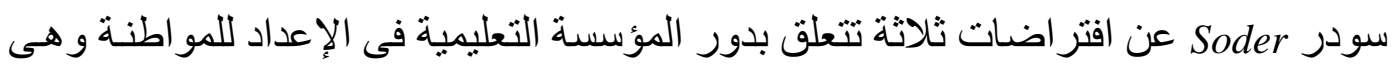

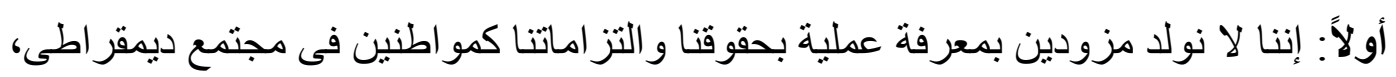

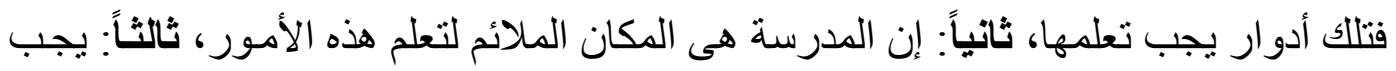

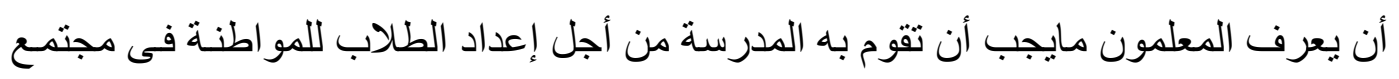

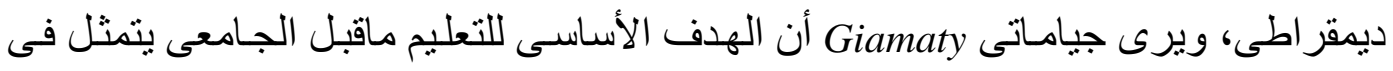

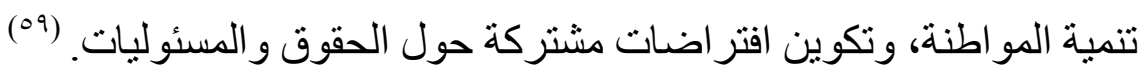
وتجدر الإشارة إلى أن المعلم يشكل أساس العملية التعليمية، ولذلك فإنـه يمكن القول

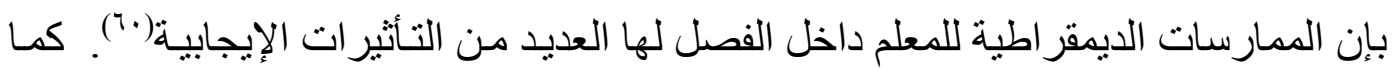

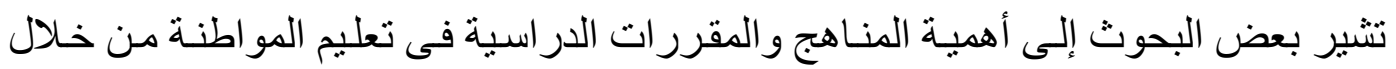

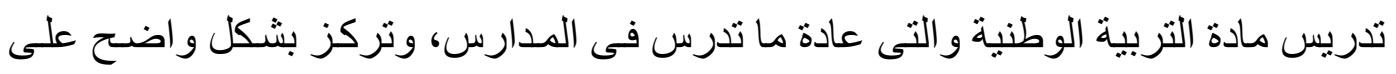

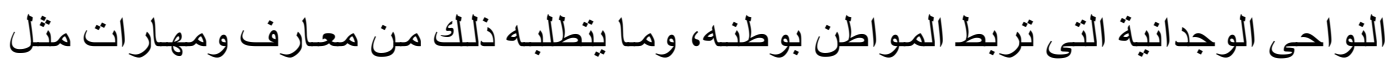

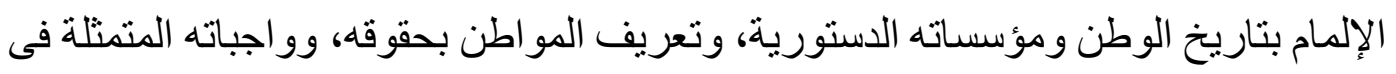

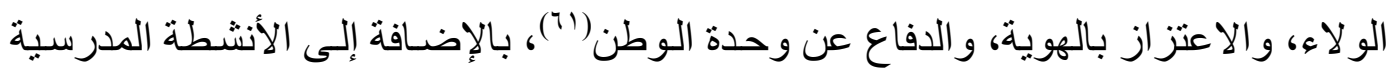

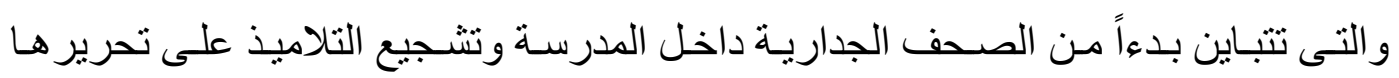

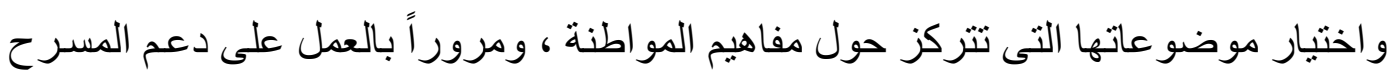

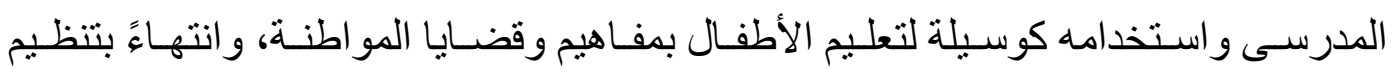

الرحلات المدرسية إلى الأماكن العامة كالمتاحف الوطنية، و المواقع الدينية، والأسرية. ويمكن القول إن هناك ثلاثة مداخل عامة تنتهجها حكومات الدول فى توظيف تعليم

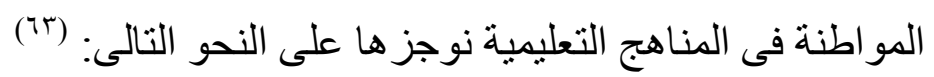
أـ تخصيص مو اد در اسية مستقلة لدر اسـة موضو عات المو اطنة، يخصص لها سـاعات در اسية ، ومعلمون متخصصون ، وامتحانات ، فعلى سبيل المثال فى دولة المكسيك،

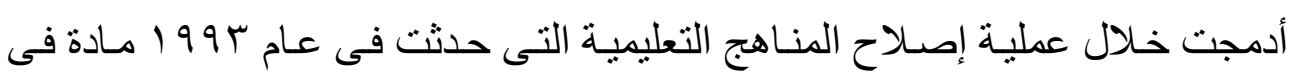

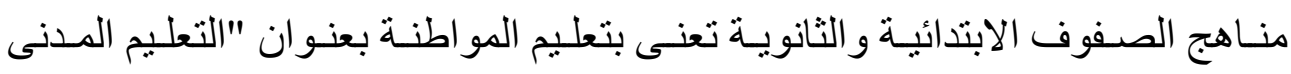

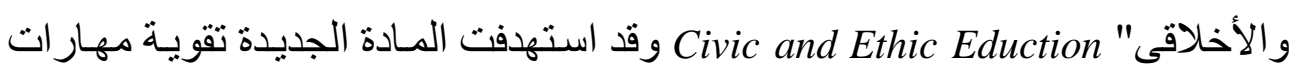

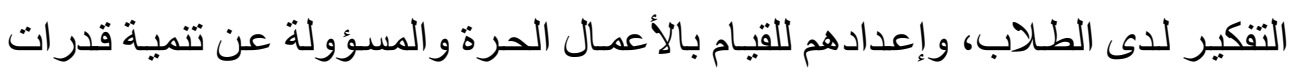


الأفر اد، وتحقيق فو ائد عملية للمجتمع حيث تسعى إلى تطوير ثمانى كفاءات: الأولى:

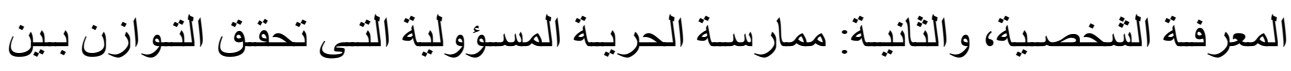

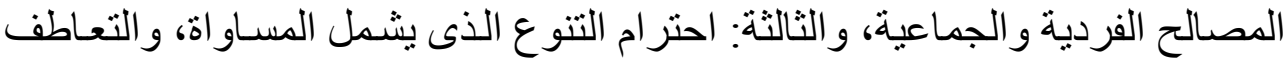

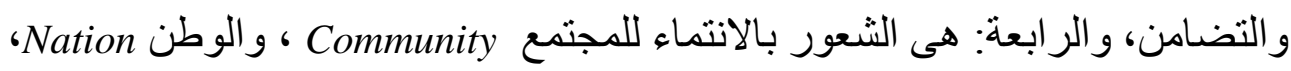

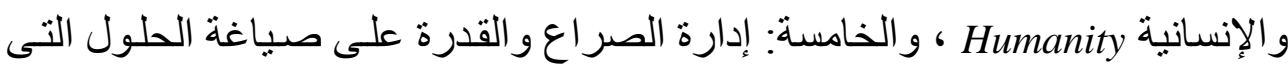
تفضل الحوار و السادسة: القدرة على المشـاركة فى الثـئون الاجتماعية و السياسية،

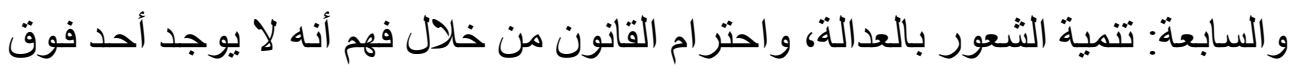

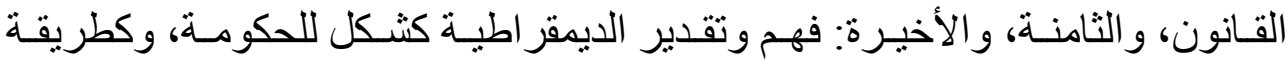
مرتبطة بأسس الحياة اليومية.

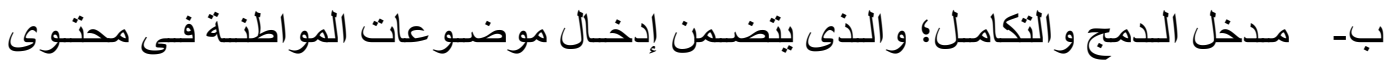

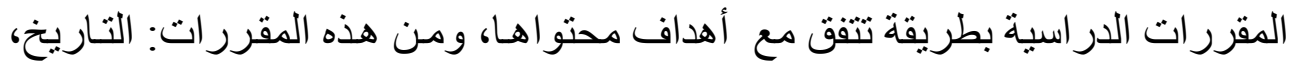

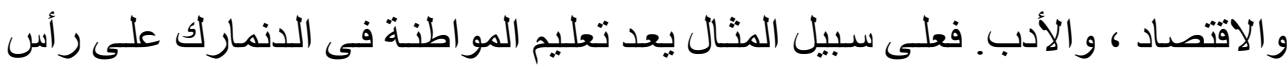

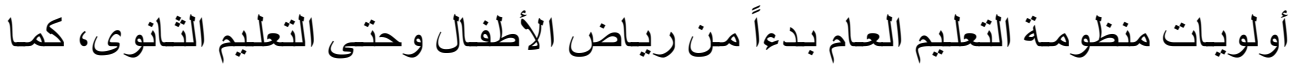

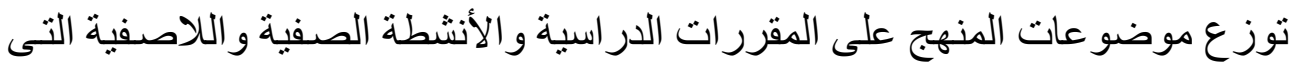

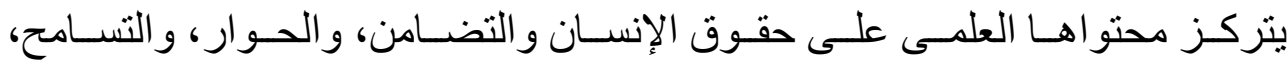

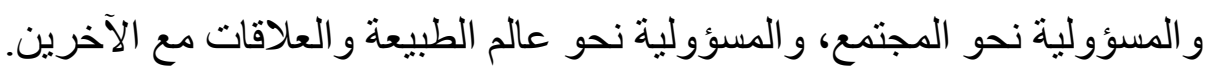
جـ - الجمع مابين وجود منهج مستقل ووجود مقررات تدرس عدد من الموضو عات ذات

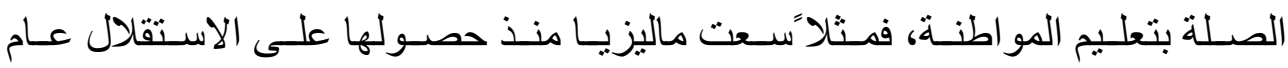

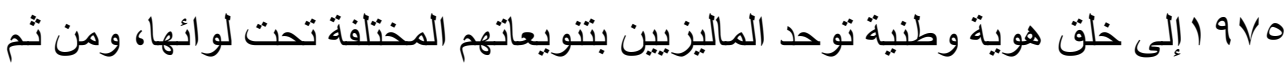

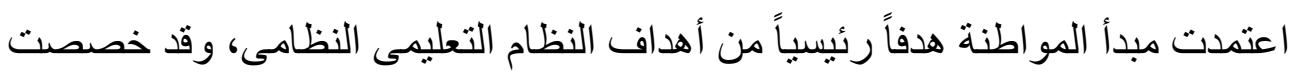

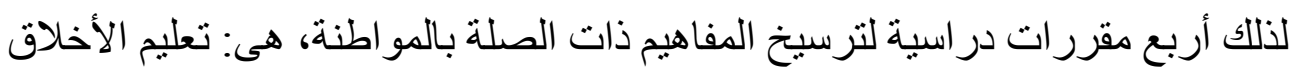
Ethics Education المدنيـة والمواطنة Civic and Citizenship Education وتستهدف هذه المقررات

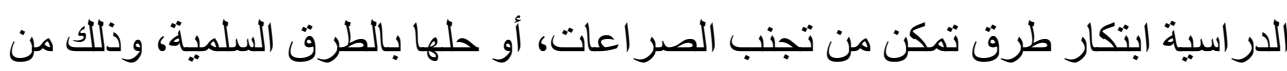

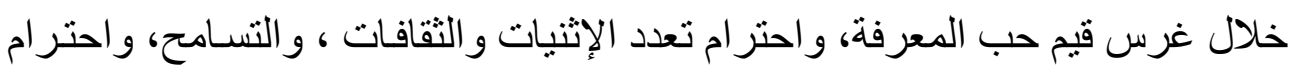
النظام العام، واحتر ام القانون، وكيفية التعامل مع الاختلافات دون اللجوء إلى العى العنف. 
و عملياً كان هنالك إجماع على أن أفضل طريقة لتعليم المواطنة هـى المدخل البنـائى Constructivist Approach ، حيث يشارك الطلاب في أنشطة هادفة تسعى إلى مسـاعدنهم

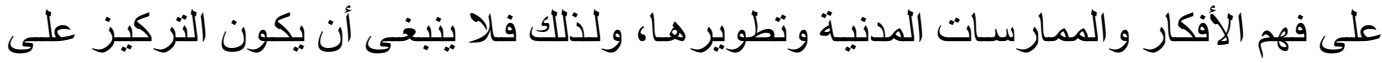
تعلم مجموعة من الحقائق فحسب ـ كما هو الحال فى التعليم المدنى التقليدى ـ بل التعلم

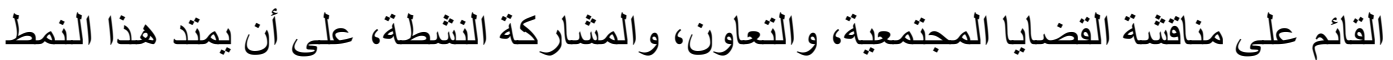

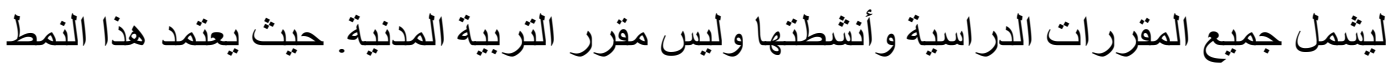
التربوى على مشاركة الطلاب فى بناء المعنى Meaning Constructing ويتشابه ذلك النمط مع تقليد جون ديوى John Dewey الذى ينطوى على التعلم التجريبى Experimential Learning الأطفال مستقبلين سلبيين للمعلومات Passive Receivers of Information فحسب ، بل يجب

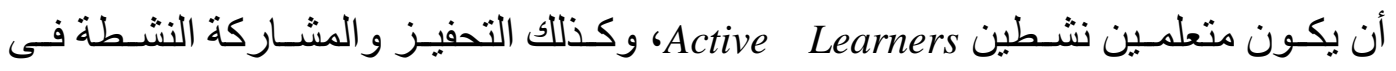

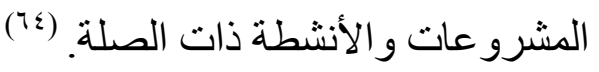

ومن أبرز الأمثلة على ماسبق إطلاق الإدارة التعليمية فى مقاطعة هامبشاير أكبر

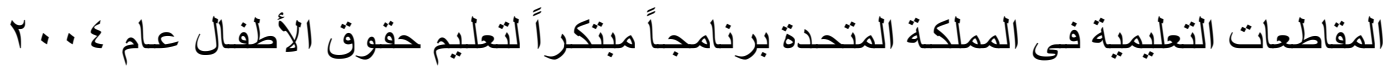
Rights, Respect, and Responsibility"أطلق عليه "برنامج الحقوق و الاحتر ام والمسئوليات

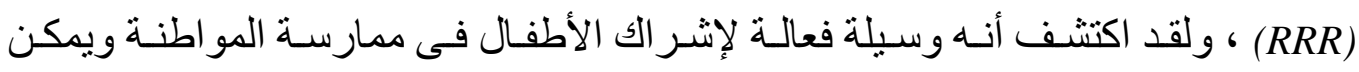

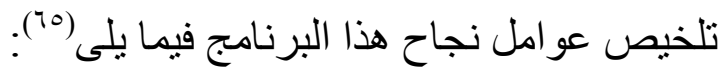
1- وفر البرنامج إطار أ قيمياً يعزز مشاركة الأطفال لأنه يتو افق مـع حياتهم اليومية ويفسح

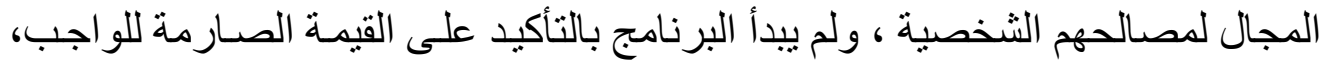

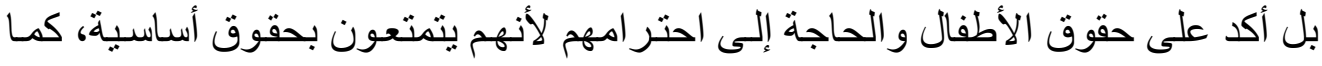

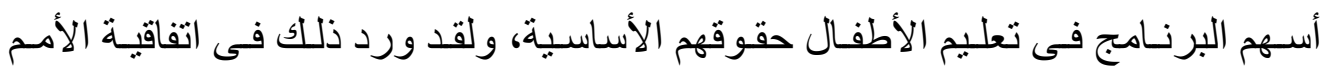

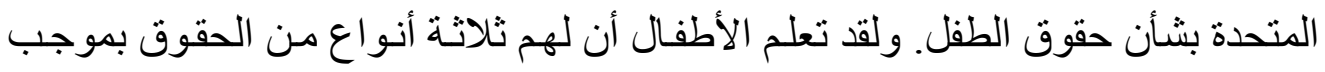

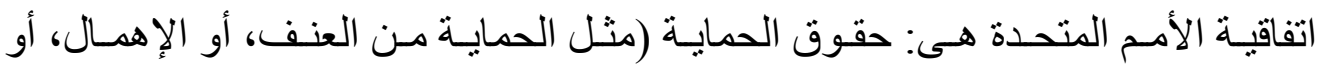

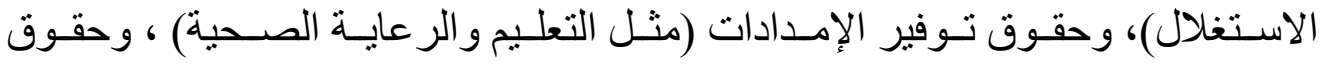
المشاركة (أن يكون لهم صوت فى مناقشة الموضوعات التى تؤثر عليهم)، وفى الوقت الته

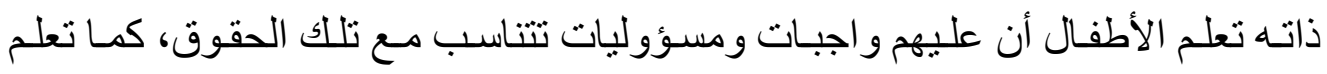

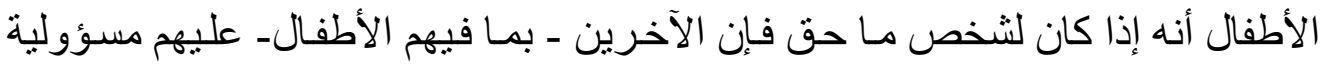

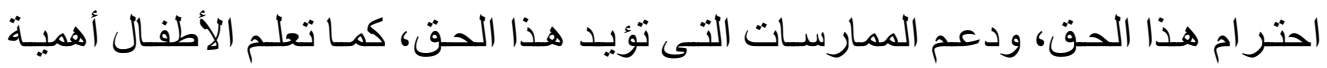


المسئولية المجتمعية ولكن ليس بطريقة توجيهية سلطوية، بل من خلال تعلم القيم التى

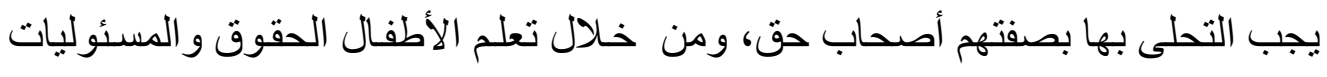
أصبح ينظر إليهم على أنهم مشاركين فاعلين ونشطين. r- تعامل البرنامج مع الأطفال على أنهم أبناء الوطن من جيل الحاضر وليس فقط على أنهم

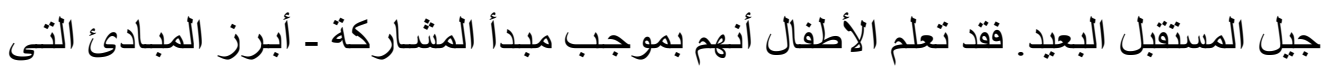

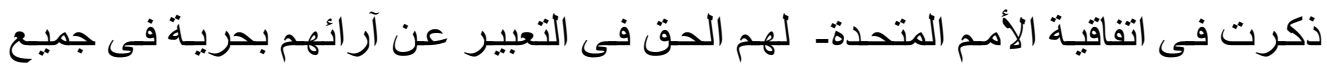

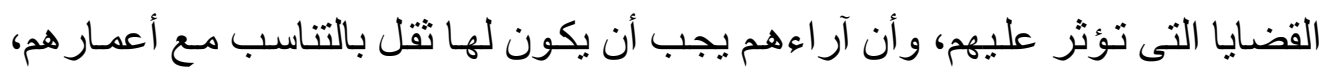
ومستويات نضجه. وتختلف هذه المنهجيـة كثير اً عن المفهوم التقليدى لتعليم المواطنة و هو المفهوم السائد فى المملكة المتحدة وجميع الدول الأخرى، حيث ينم تدريب الأطفال

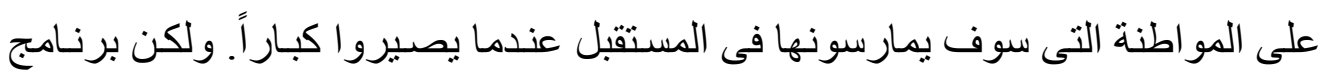

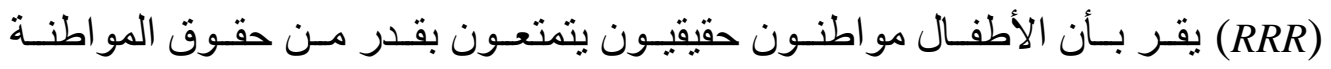

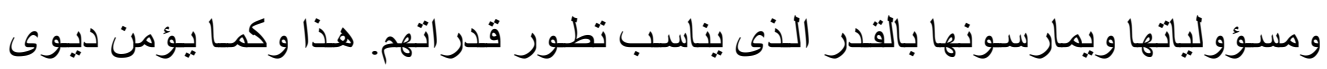
فewey

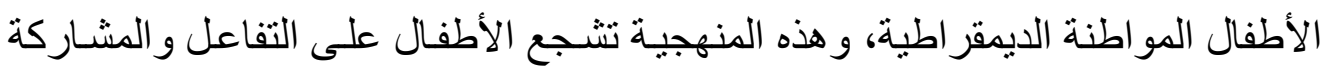

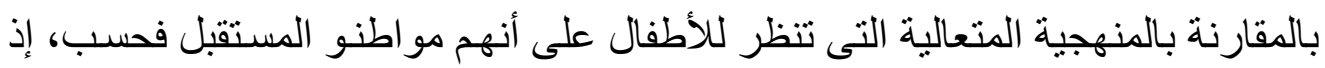
أن هذه المنهجية تستجيب لمشاعر الأطفال ور غباتهم فى الحاضر. r- يفسح البرنامج المجال للتفكير الأخلاقى وغرس القيم، حيث يرتكز على التعليم والتعلم

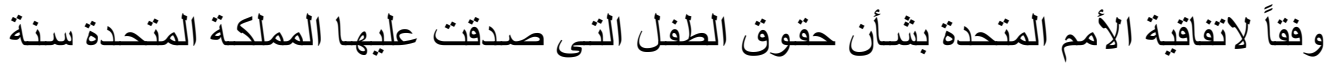
1991 (مثلما صدقت عليها استر اليا سنة . 199 و وكندا سنة (1999 ) وقد تعلم الأطفال أن المملكة المتحدة إذ صدقت على الاتفاقية فهذا يعنى أنها تو افق على مبدأ أن الأطفال

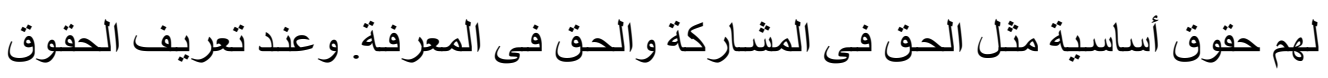

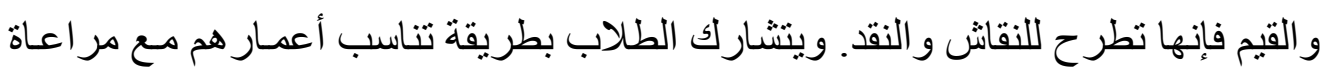

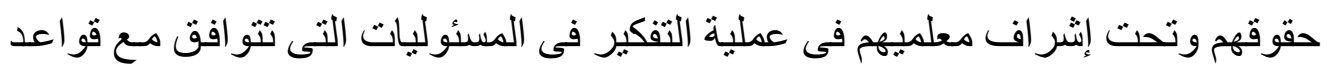

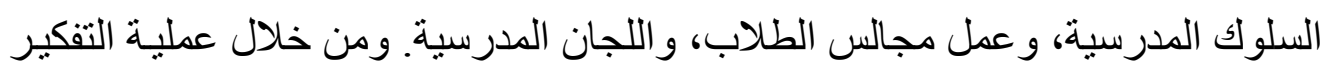

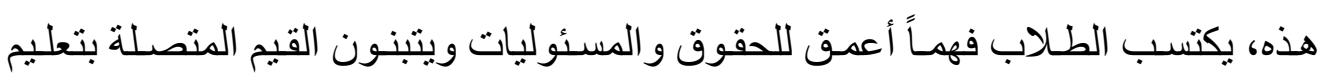

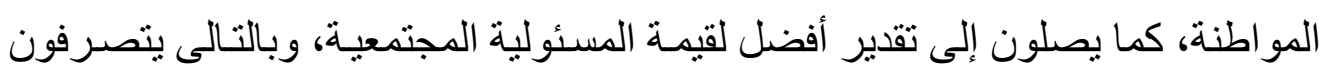

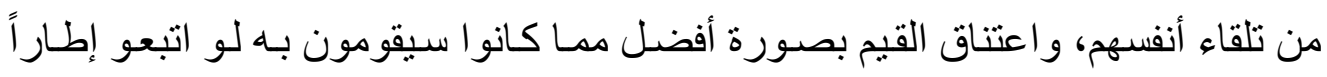

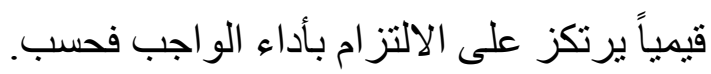


ــ - يصر "برنامج الحقوق و الاحترام و المسئوليات" على ممارسات المشاركة التى تتمانشى

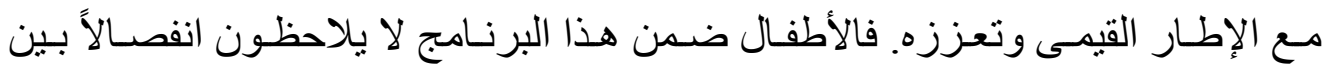

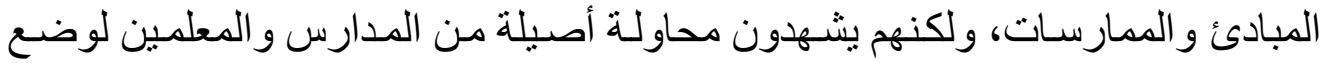

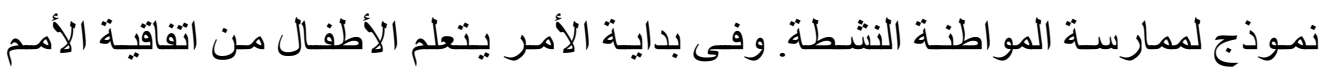

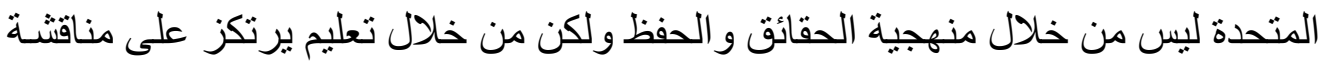
القضايا و التعاون و المشاركة النشطة. كما يتعلم الأطفال حقوقهم ومسئولياتهم من خـلال عملية أداء الأدوار التى تتسم بالتفاعل و إكساب الخبرات، بالإضافة إلى تعلم التعاون بين مجمو عات صغيرة ومناقتــة القضـايا الجدلية فى فصول تثـار كية. وقد لوحظ أن أداء

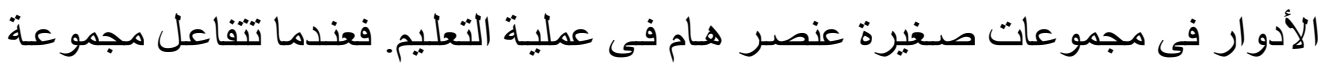

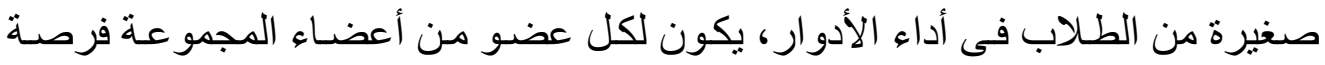

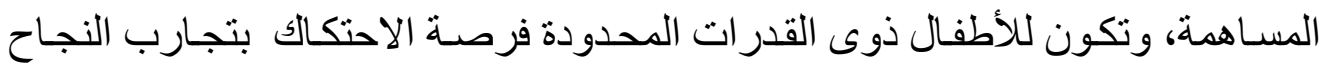
فى حين يتمكن الطلاب المو هوبون من التعبير عن قدر اتهم الإبداعية. وقد أثتبت التجرية

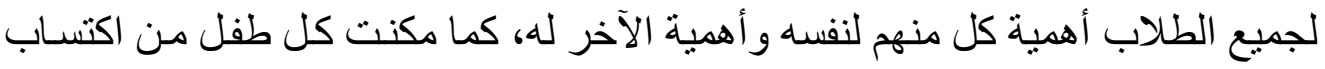

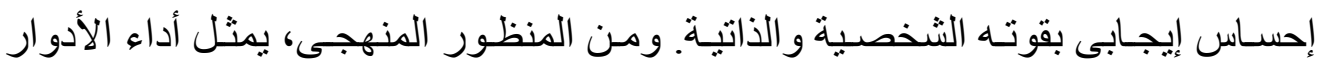
تجربة تفاعلية للأطفال يذكرونها دائمـا أكثر من إستر اتيجيات التعلم التقليديـة، كمـا أنـه أكثر فاعلية فى تنمية قدرة الطلاب على التو اصل و النقاش. ๑ـ لا يقتصر التعليم من أجل المواطنة على التعليم داخل صف در اسى معين، بل إنه مدرج

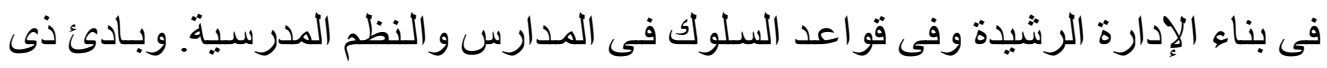

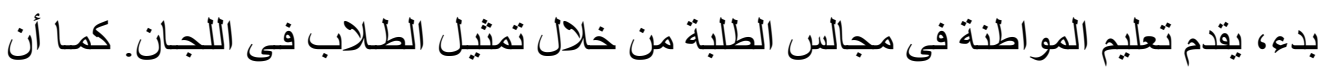

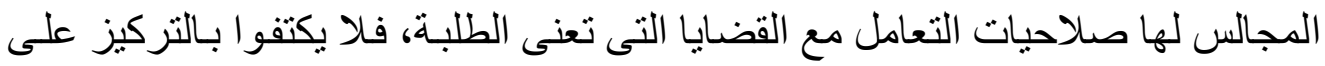

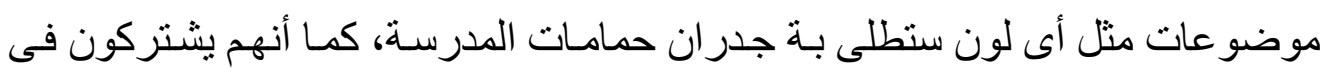

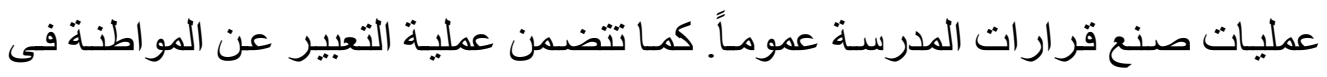

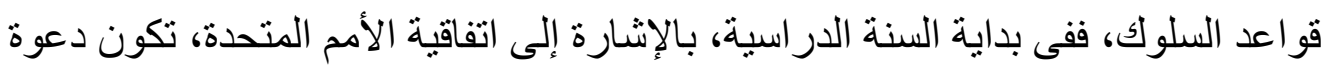

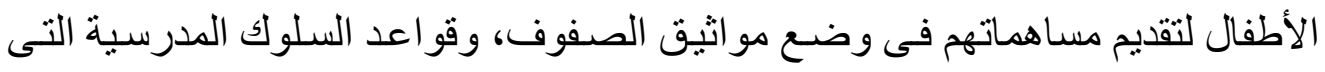
تتضمن معايير السلوك للسنة الدراسية و التى تكون مصـاغة بلغة الحقوق و المسئوليات ويمكن القول إنه خلال السنة الدراسية، إذا أخل طالب بحقوق طالب آخر (مثل حق التعلم أو اللعب)، أو قصر فى أى من مسئولياته (مثل احتر ام حقوق الآخرين وممتلكاتهم) 
يتعرض هذا الطالب للمسـاءلة على أسـاس القانون، أو الميثاق الذى شـارك بنفسه فى

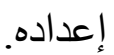

\section{رابعاً: القصور فى تعليم المواطنة:}

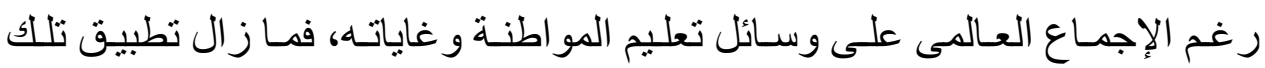

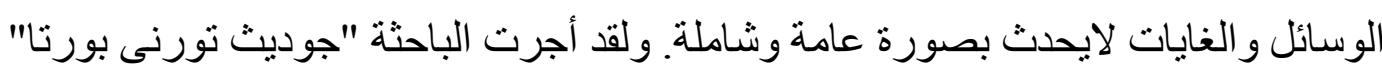
Judith Torney-Purta

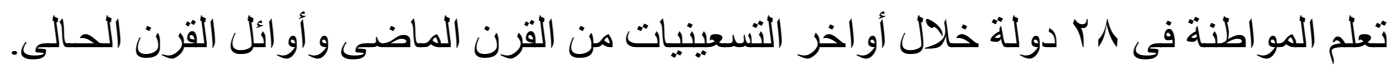

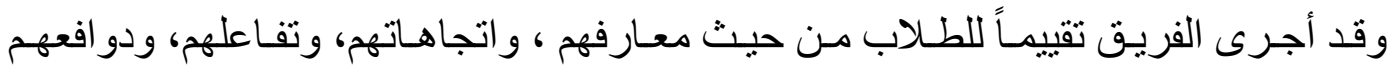

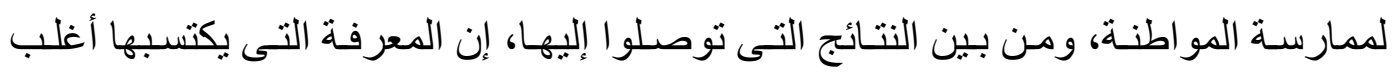

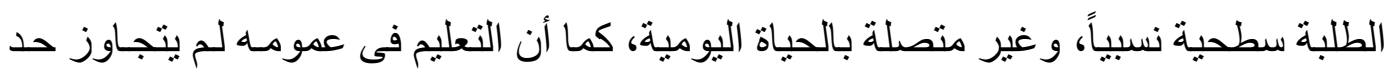

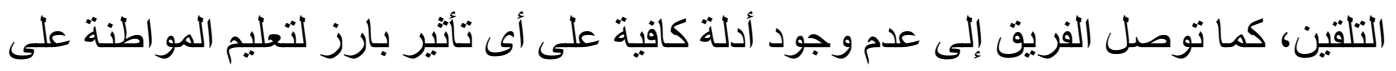

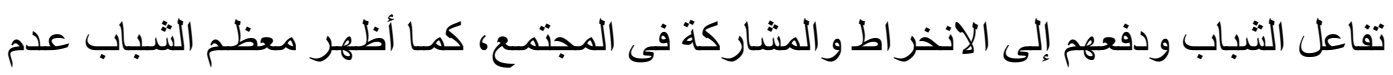

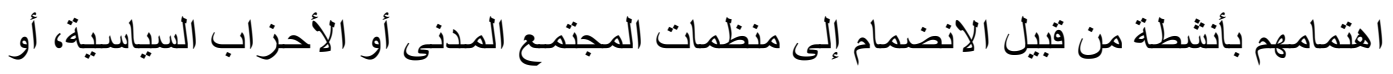

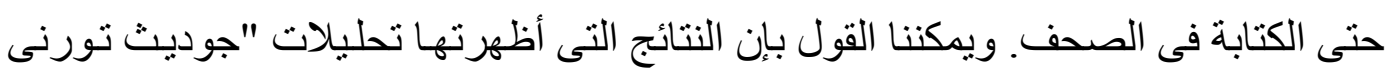

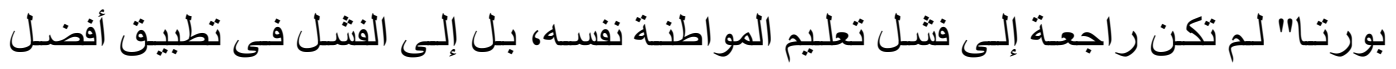

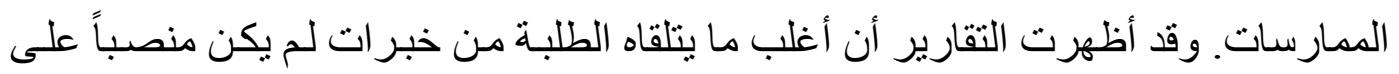

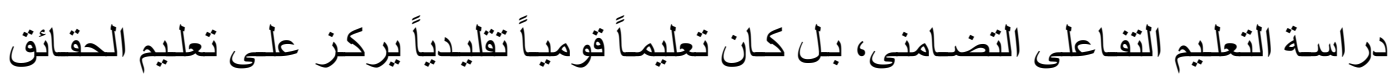

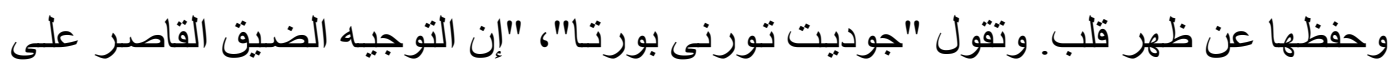

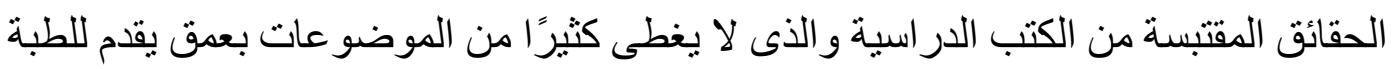

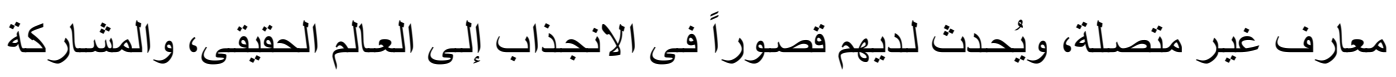

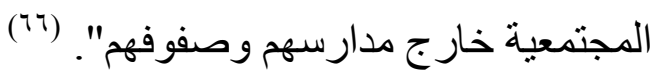

ومن ناحية أخرى، قدمت كارول هان Carole Hahn دلائل قويـة على مايؤدى إليه

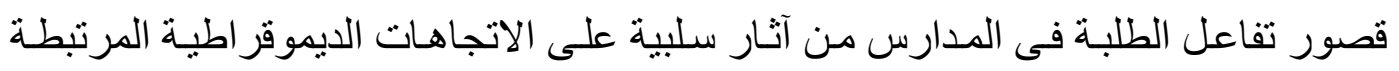

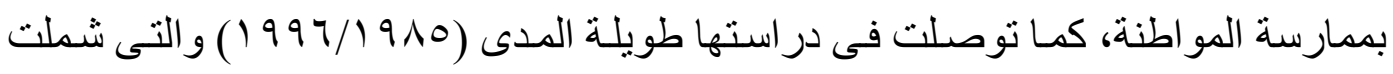

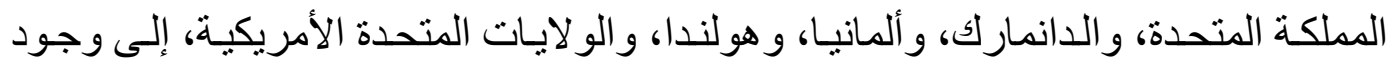

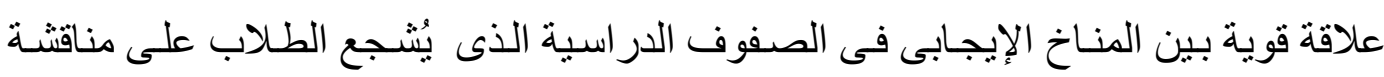

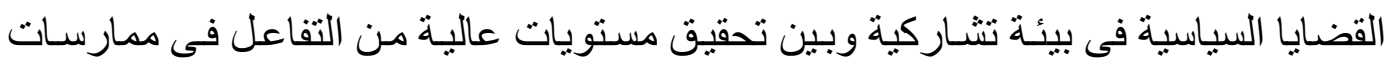


المو اطنة، وتقول إحدى أهم النتائج بإنه كلما كانت الصفوف الدراسية تدار إدارة ديمقر اطية

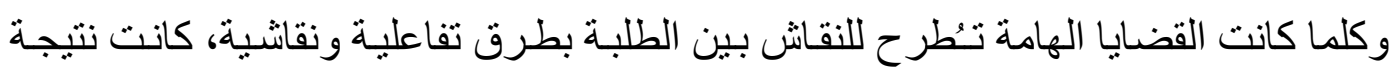

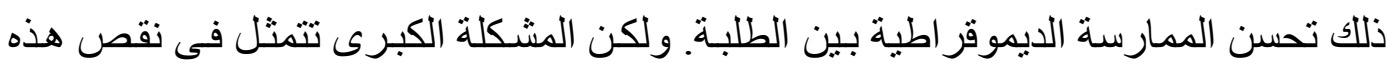

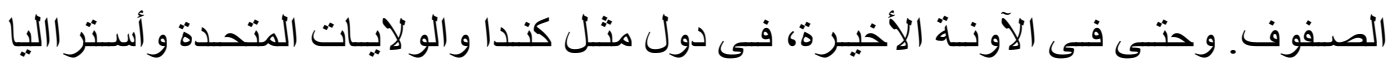

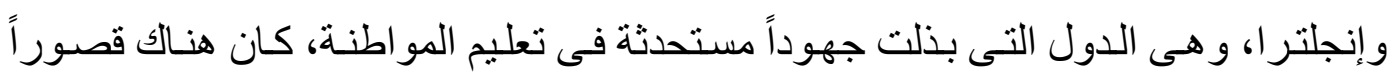

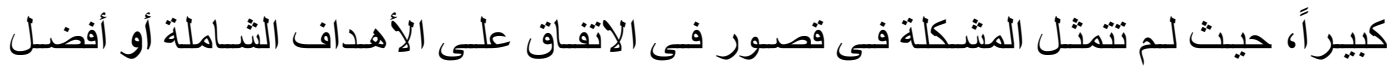

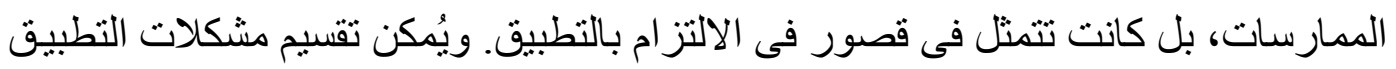

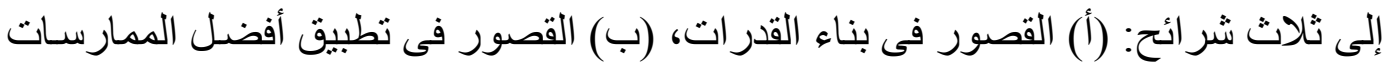

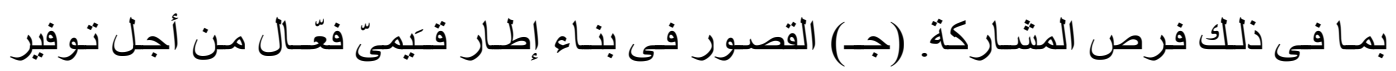

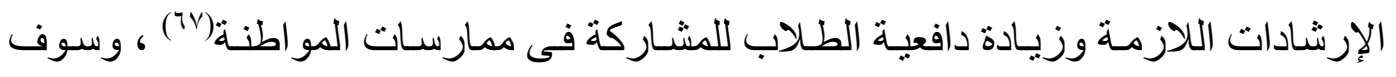
نتناول تلالك المشكلات بشئ من التفصيل وذلك على النحو النالى: 1 - القصور فى بناء القدرات:

لقد حدد هوجيز وسيرز Hughes و بناء القدرات من أجل تعليم المواطنة فى إنى

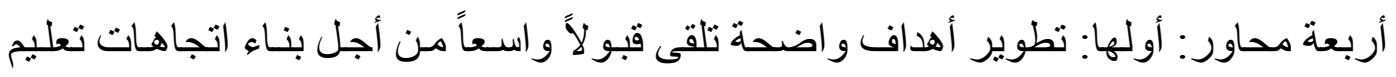

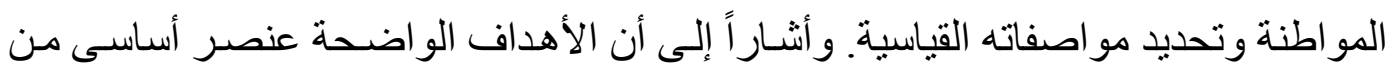
أجل التعليم و التعلم الناجحين وكذللك التطبيق الجيد. ومع أن الأهداف المحددة يصعب التهابل التركيز

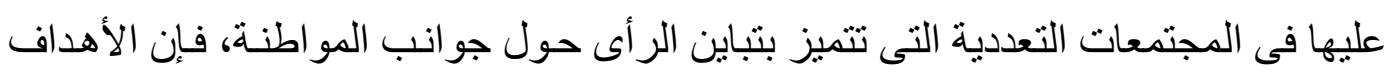

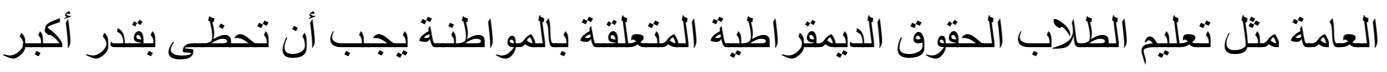

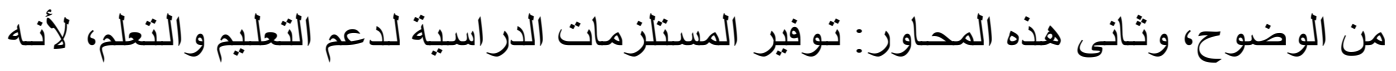

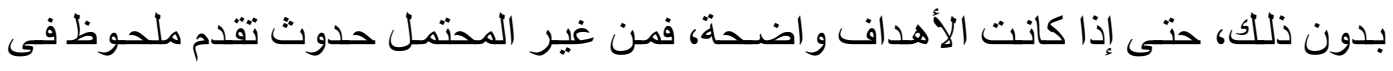

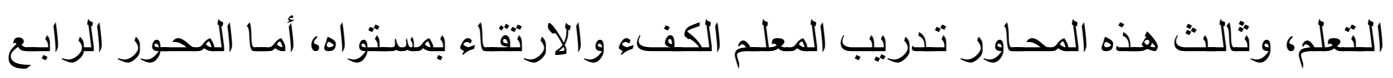

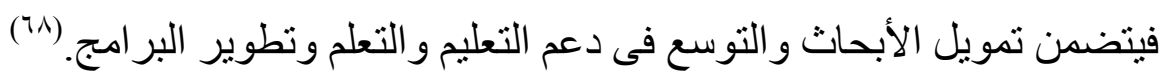
ووفقا لما ذكره هوجيز وسيرز فمـع أن بعض الدول قد حققت تقدماً ملحوظاً، فـان

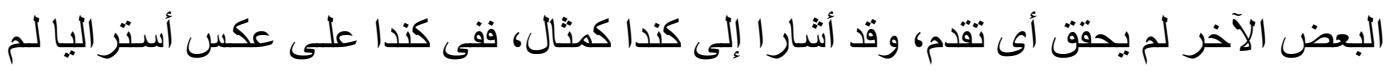

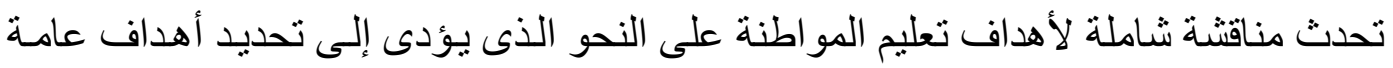

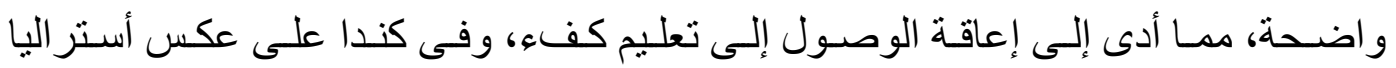

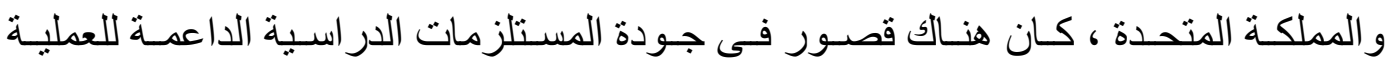
التعليمية، ودائما ما كان ينظر المعلمون الكنديون إلى قصور المستلزمات الدراسية على أنهـ 
عائق كبير، و إضافة إلى ذلك لم يكن هناك تدريب كاف للمعلمين بالإضـافة إلى عدم تطوير بر امج لتعليم المواطنة. و على عكس المملكة المتحدة التى وفرت تدريبات كثيرة ومتباينة لتعليم المو اطنة و التى تقدم جامعاتها مجموعـة كبيرة من بر امج الدر اسـات العليا، فقد عانت كندا من قصور مثل هذه الفرص. و أخير اً كان هنالك قصور فى تمويل الأبحاث الداعمة لتعليم المو اطنة، و على النقيض من المملكة المتحدة التى وضـعت نظامـاً متعدد المستويات للبحث و المر اقبة و التقييم، كان بناء القاعدة البحثية فى كندا متناثر اً ومشتناً. (79) r - القصور فى تطبيق أفضل الممارسات: تتضــن المشـكلة الثانيـة عدم تطبيـق أفضـل الممارسـات، ففـى اسـتعر اض التطـور Ian Davies الأخير للبر امج التعليمية فى كندا وأستر اليا والمملكة المتحدة، ذكر إيان ديفيز وجون إسـيت John Issitt أن المنـاهج السـائدة لتعليم المواطنـة لا تز ال محافظـة وتجريبيـة وليست نتاركية وبنائية. وقد توصلا إلى هذا الاستنتاج بعد در اسـة وتحليل محتويـات الكتب المدرسية ومو اد المناهج المستخدمة فى كل من هذه الدول. ووفقاً لتحليلاتهما، ففى كندا ( مـع التركيز على مقاطعة "أونتاريو" لا تز ال عملية تعليم المواطنة تحدث بشكل أساسى فى أطار الثكل التقليدى للتربية المدنية حيث أنه مدخل محافظ لا يتسم بقدر كبير من الفعالية، إذ يهتم بنقل المعلومات حول تطوير الديمقر اطية البرلمانيـة، مـع بعض التشجيع على المشـاركة فى إجر اءات مؤسسية محدودة، والهدف العام هو مله عقول الطلاب بالحقائق، وليس تشـيع المو اطنة النشطة بطريقة جادة من خلال الصفوف الدر اسية التشاركية، ومن الهام أن نلاحظ مع ذلك، أن هذا المدخل المحافظ ليس متجانساً عبر كافة أرجـاء كندا. فعلى سبيل المثنال فى مقاطعـة "كولومبيـا البريطانيـة"، و "ألبرتـا" كـان هنـاك اعتمـاد على مـداخل أكثر نثـاركية وفعالية لتعليم المواطنة، فعلى سبيل المثال، على الر غم من كونها مـادة اختياريـة، تعتبر الدر اسـات المدنيـة "Civic Studies 11 " فيى المدارس الثانويـة فيى "كولومبيـا البريطانيـة" و احدة من أكثر البر امج تقدماً فى أى مكان فى البلد. ولكن على الرغم من هذه الاستناءات لم يكن هناك تطبيق لأفضل الممارسات بشكل عام فى كندا. (v.)

كمـا فثـلت المـدارس بشـكل عـام فـى تـوفير الفـرص و الأسـاليب الملائمسة لضـــان المشاركة النشطة للطلاب، حيث فضلت بدلاً مـن ذلك الحفاظ على الأسـاليب التقليديـة مثل تلقين الحقائق (من الأعلى إلى الأسفل)، أو تضبيق وتقييد فرص المشــاركة، والتفكير النقدى لهـ حول القضايا السياسية. بل حتى فى المملكة المتحدة، كان هناك إثـارة صـريحة إلى "أهميـة الحاجة إلى تطوير ودعم الاهتمام بعملية المو اطنة كممارسة فعالة فى المناهج"، وحتى عندما 
تكون هنالك مجالس طلابية فقد اقتصرت على مناقتشة قضـايا عاديـة ليس فيها قدر كبير من

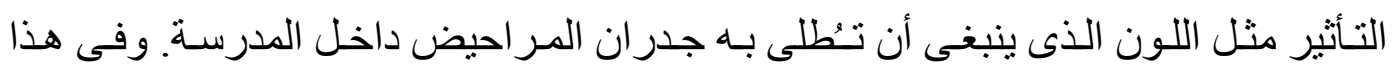

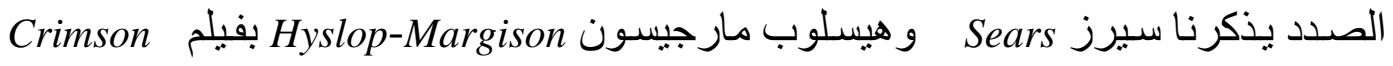

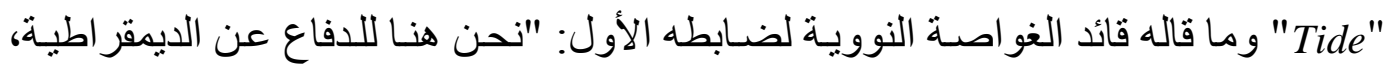

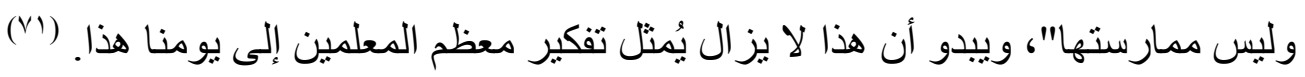
بالإضافة إلى ماسبق كان هنالك فنشل فى توفير التكامل فى تعليم المواطنة فى جميع

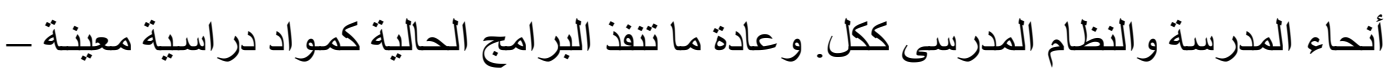

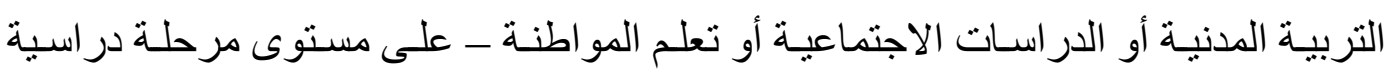

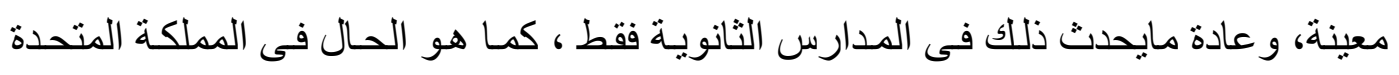
على سبيل المثال. وفى المقابل لم يعط سوى قليل من التفكير في الحاجـة إلى تكامل تعليم

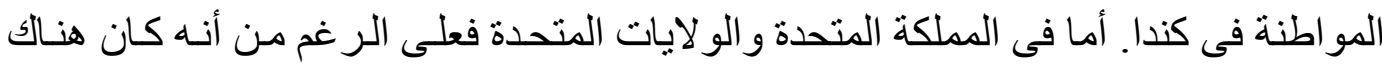
عدد من المبادرات بالفعل، فليس ثمـة تحرك كبير فى اتجـاه القدر المطلوب من التكامل.

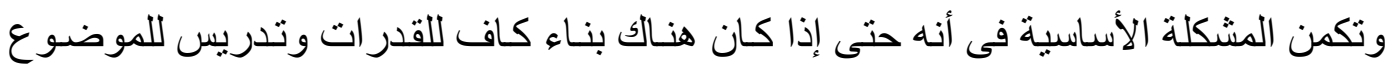

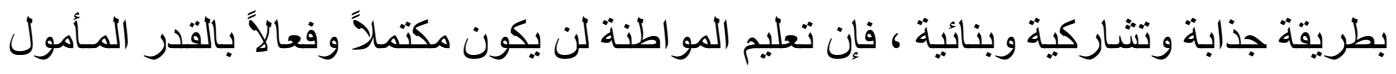

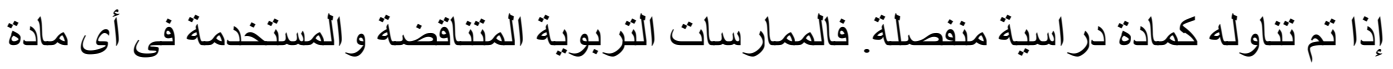

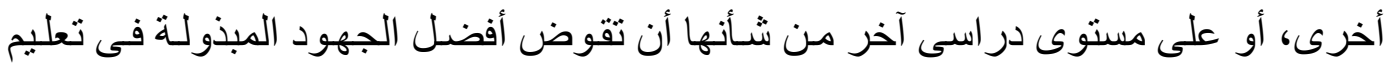
المواطنة.

وكما لاحظ بايك Pike ، أنه على الرغم من إن إدماج تعليم المواطنة هو أكثر وسـائل

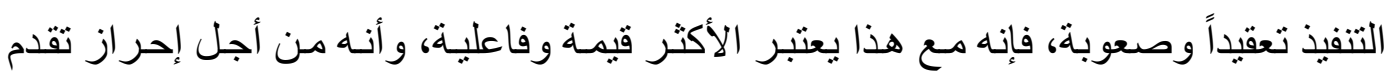

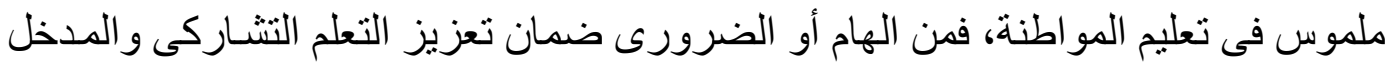

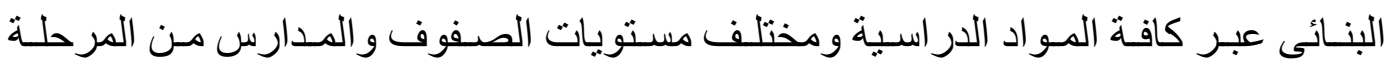

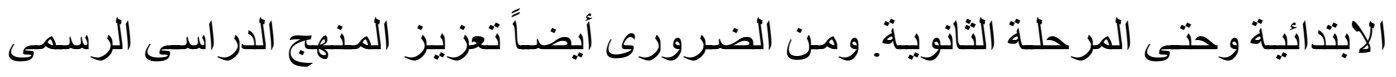

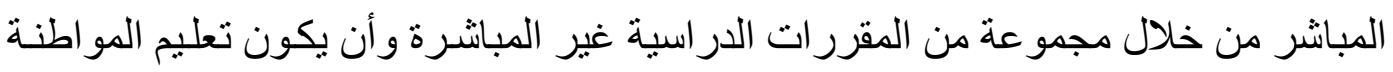

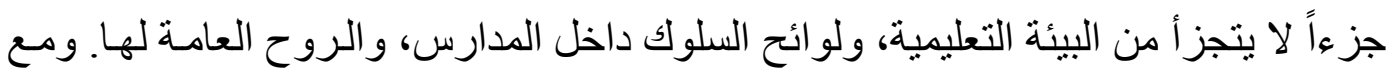

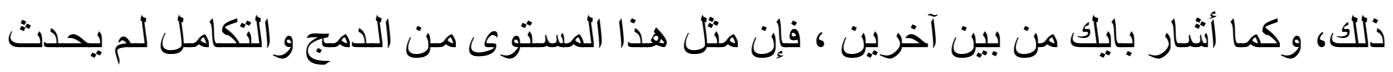

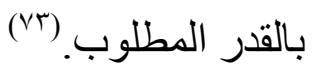




\section{r- القصور فى الإطار القيمى:}

تتمثل المشكلة الثالثة فى عدم وجود إطار قيمى فعال، أو نسيج أخلاقى موحد لتعليم

المو اطنة. فحتى إذا كان هناك بناء للقدرات وجهود حقيقية فى التنفيذ، دون وجود إطسار قيمى فعال لإشر الك الطلاب وتحفيز هم على ممارسة المو اطنة بفاعلية، فسيكون التقدم محدوداً بـلا

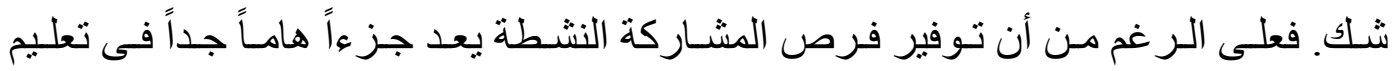
المو اطنة فإن الطلاب بحاجة إلى التحفيز على متابعة تلك الفرص، إذ إنهم بحاجة إلى تعزيز المشاركة النشطة مـن قبـل المدرسـة، بحاجـة أبضـاً إلى رؤيـة حقيقيـة فى ممارسـة المو اطنـة. و هذا يتطلب أن يصطبغ تعليم المو اطنة بصبغة أخلاقية و إطار قيمى جذاب. وتكمن الصـوبة فيى أنـه منذ الحرب العالميـة الثانيـة غالبـاً مـا كانـت السلطات التعليميـة فيى العديد من الدول الغربية منرددة فى الترويج لقيم مستقلة تتعلق بالمو اطنة، ولقد كان السبب الرئيسى فى ذلك هو أن التدريس الصريح لمجمو عة معينة من القيم الأخلاقيـة والسياسية المرتبطة بالمو اطنة يعتبر مشـكلة فى مجتمـع علمـانى وتعددى حيـث توجد وجهات نظـر مختلفـة حـول القيم الأساسية. فبالنسبة لبعض المجتمعات، قد تكون الحياة الدينية أو النجاح الاقتصسادى ذو أهمية أساسية، بينمـا تعد ممارسـة المو اطنـة بفاعليـة ذات أهميـة ثانويـة أو ضـئيلة. ولذلك يحـاول المعلمون أن يكونو ا محايدين أو أن تكون مناقثـة القيم على مستوى عـام جداً. ولذللك يمكن القول إنه يوجد اتفاق فيما بينهم على تدريس ماوصفه مـاكلوج T.H. Mclaugh بالحد الأدنى مـن مفهوم المو اطنـة حيـث ينصـب التركيز على نقل المعرفـة ومجموعـة مـن المهـار ات الأساسية بدلاً من تعزيز قيم معينة (وذللك على النقيض من مفهوم "الحد الأقصى" الذى يكون

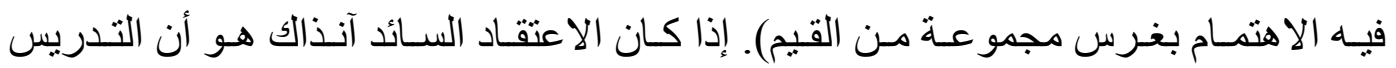
الصريح للقيم يجب أن يترك إلى حد كبير للآباء و المنظمات المجتمعية. (Y)

ويمكن القول أن البرنامج التعليمى فى المملكة المتحدة ذو طابع تقدمى فى العديد من النو احى و التى تتمثل فى التركيز على قيمـة المشـاركة و السماح للطـلاب بـالإدلاء بـر أيهم فى العديـد مـن القضـايا مثنل قو انين وسياسـات السـلوك المدرسـى، إذ يرحب الطـلاب بالثـعور بالانتماء إلى مجتمـع مـا ويعتقدون أنه يجب أن يكون لديهر صـوت في المسـائل التى تؤثر عليهم. لذا فالبرنامج لديه إمكانات كبيرة بالفعل، إلا أن مستوى الفعالية و آليات التنفيذ ماز الت موضع شك. ويرجع ذلك إلى أن البرنـامج ذاته يمثل مشكلة لأنه يعامل الأطفال كمو اطنين مستقبليين بـدلاً مـن مـو اطنى الحاضـر ؛ إذ يتعلم الأطفال أنهم فحى مرحلـة تدريب ليصـبحوا

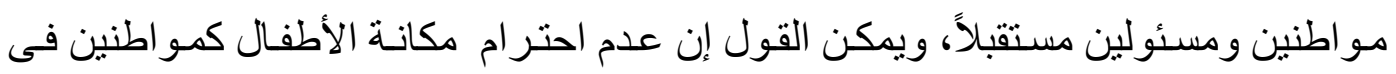


الوقت الحاضر، إلى جانب التركيز الصارم على تتمية الثتعور لديهم بالو اجب و الالتزام، لا

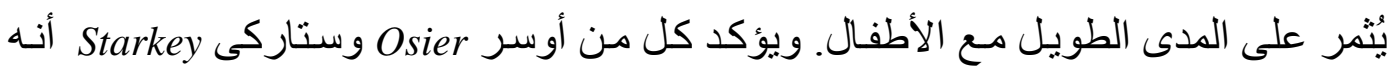

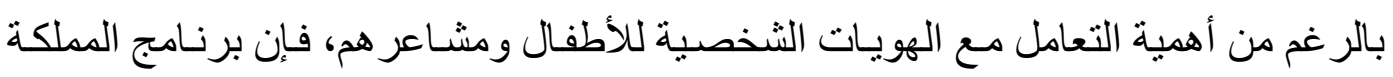
المتحدة لا يفعل ذلك بصورة كبيرة.

وعلاوة على ذلك، وكما أورد Don Rowe فى إنشارة إلى الأدبيات و الأبحاث المتعلقة

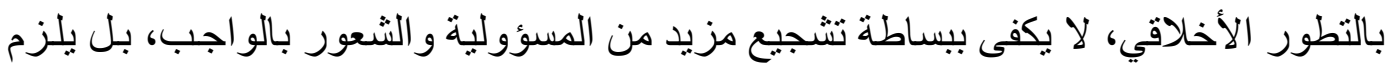

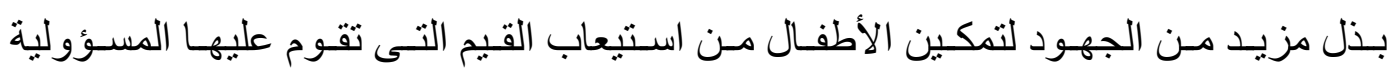

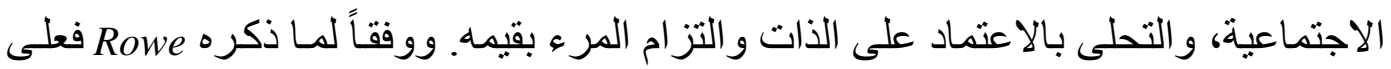

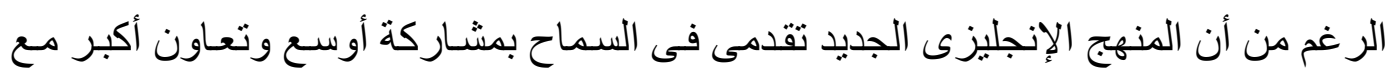

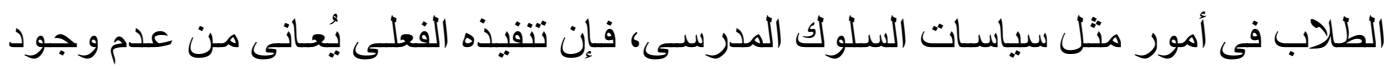

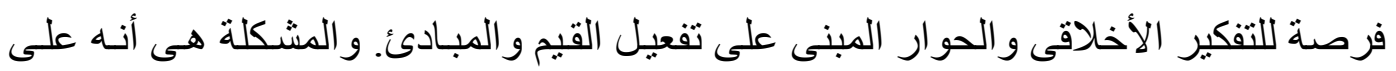

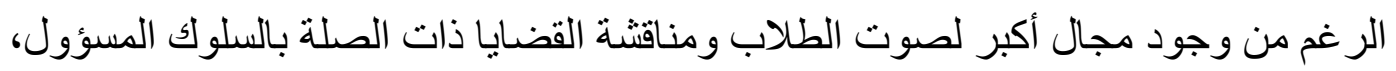
فإن المناقتنـة تميل إلى البقاء على المستوى السطحى، وهو مهو مـايكفى للحصول على اتفاق

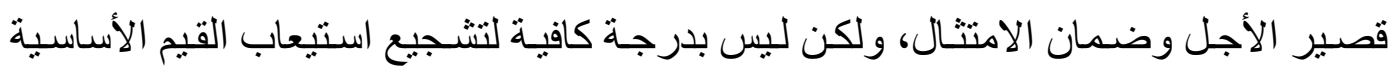

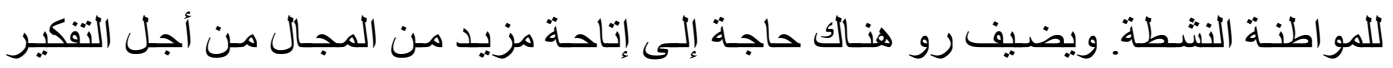

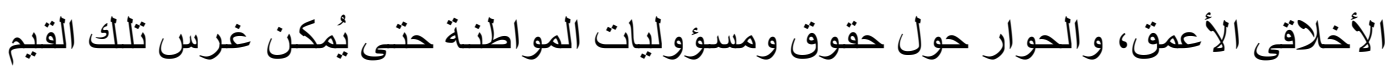

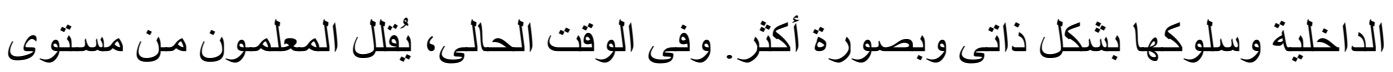

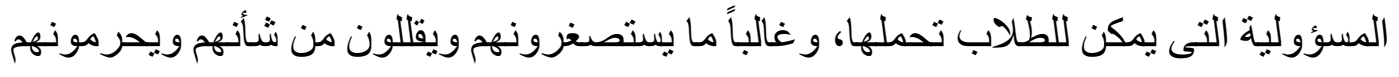

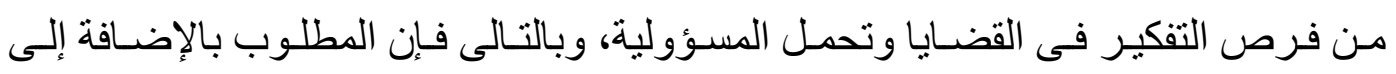

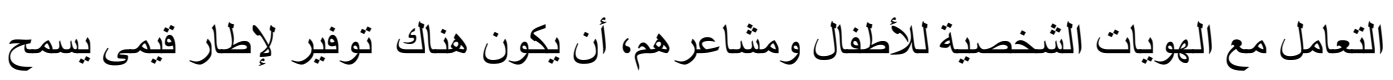
بالتفكير المتعمق حول مبادئ المواطنة، وكيفية ممارستها بفاعلية.

كما قد يتعلم الأطفال الأهمية النظريـة للمشـاركة النشطة و المناقثـة النقدية للقضـايا.

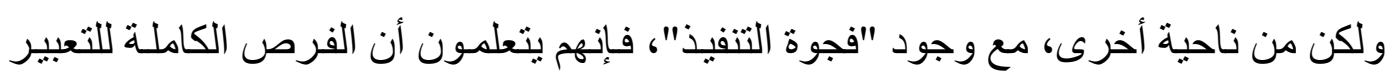
و المشاركة الهادفة تتقلص فى الصفوف الدر اسية و المدرسة، فعلى الرغم من فن التقدم الكبير

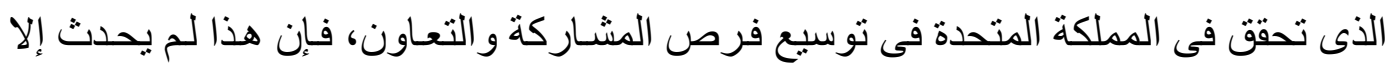
فى مستوى التعليم الثانوى فقط. 
ا - يبرز دور الأسرة فى عملية تعليم المواطنة من خلال أدوار المحاكاة والتقليد أو القدوة

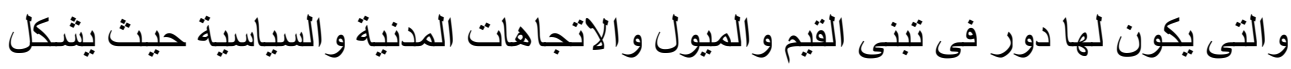

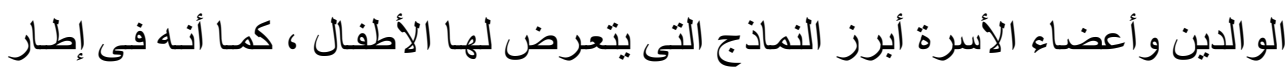

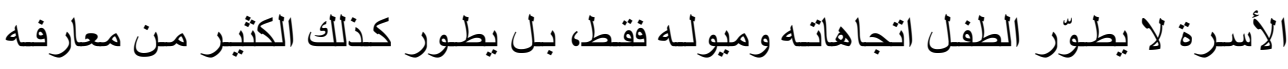
و مفاهيمه السياسية الأولية، والتى تتعلق بالوطن، و السلطة، والحقوق، و الو اجبات.

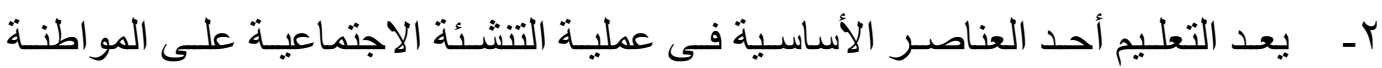

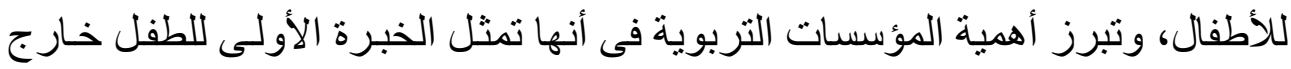
الأسرة حيث تلعب المدرسة دور أ أساسياً فى تعليم المو اطنة.

r- تتضمن عملية المواطنة الحقوق التى يجب أن يحصل عليها الطفل، وكذلك المسئوليات التى تدعم احتر ام الحقوق، ولكن لا يكون ذلك بطريقة سلطوية، بل من خلال تعليم

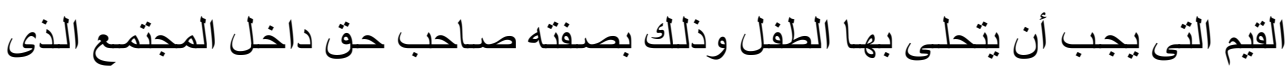
يعيش فيه ومن خلال تعلم الأطفال الحقوق و المسئوليات أصبح ينظر إليهم على أنهم مشاركين فاعلين داخل مجتمعاتهم. ع-أن تعليم الطلاب الحقوق الديمقر اطية يتضمن توفير المستلزمات لدعم التعليم، و التعليم من خلال تدريب المعلم الكفءُ والارتقاء بمستو اه المهنى. 0ـ دعم فرص المشاركة النشطة للطلاب داخل الفصول الدراسية، وكذلك تثجيع الطلاب على التفكير النقدى حول القضايا المجتمعية.

7- لا يكفى أن تكون هنـالك مقرر ات در اسية لتعليم المو اطنة، بـل يجب أن يكون هنـاك

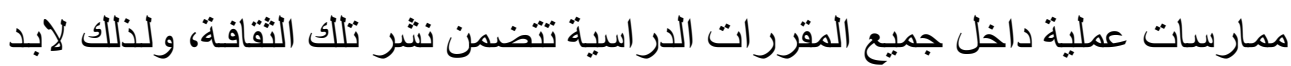
أن يكون تعليم المواطنة جزء لا يتجز أ من البيئة التعليمية. 


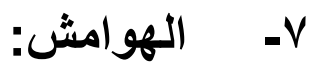

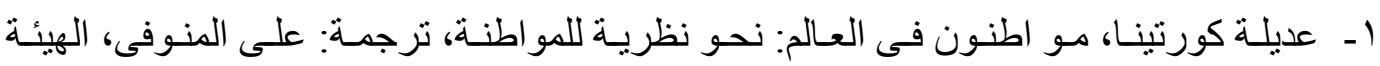

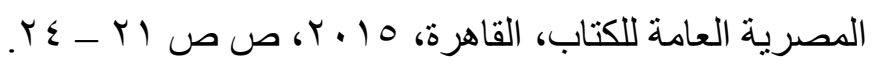

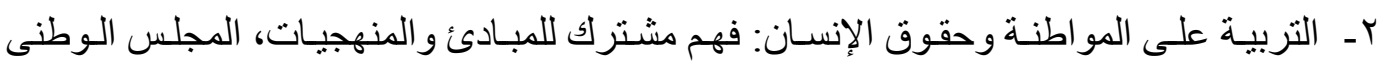

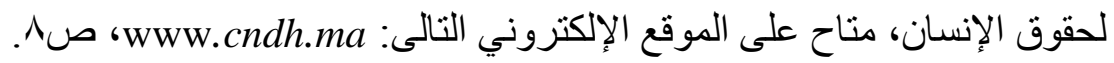

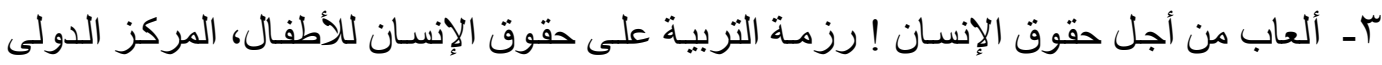

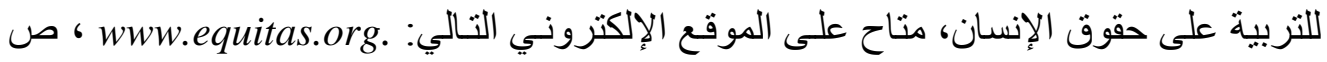

4- Marc Jans, " Children As Citizens: Toward a Contemporary Notion of Child Participation", Childhood, Vol (11), No (27), 2004, P. 27.

5- Ibid., P. 34.

6- Ibid., P. 28.

7- Ibid., P. 29.

8- Ibid., P.30.

9- Ibid., P. 30.

• اــ التربية على المو اطنة وحقوق الإنسان: فهم مشترك للمبادئ و المنهجيات، مرجع سابق، ص

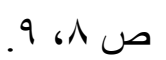

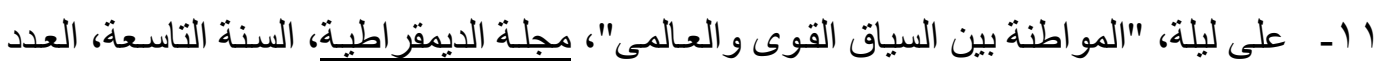
( إ)

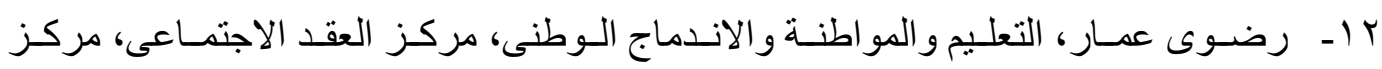

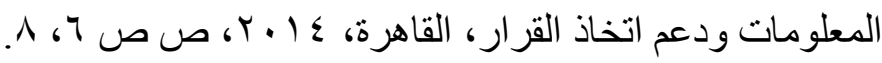

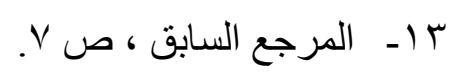

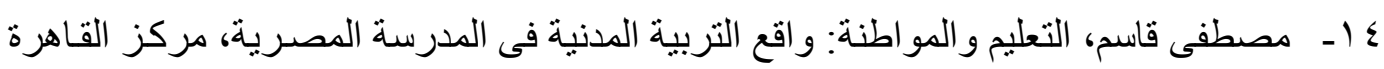

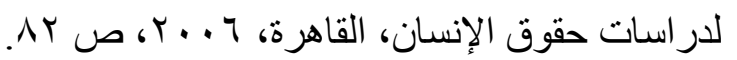

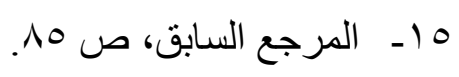

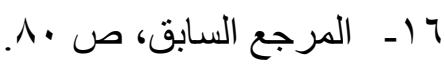

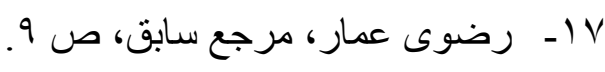

18- R. Brian Howe, et. al., "Engaging Children in Citizenship Education: A Children's Rights Perspective", Journal of Educationl Thought, Vol (43), No (1), 2009, P. 22.

19- Ibid., P. 23.

20- Ibid., P. 22. 
21- Ibid., PP. 23, 24.

22- Ibid., P. 24.

23- Ibid., PP. 25, 26.

§ זـ ألعاب من أجل حقوق الإنسان! رزمة التربية على حقوق الإنسان للأطفال، مرجع سابق، ص ع.

25- Marc Jans, "Child Participation Op. cit., P. 40.

26- Jeremy Roche, "Children: Rights, Participation and Citizenship", Childhood, Vol. (6), No (4), 1999, P. 482.

27- Ibid., P. 40.

28- Marc Jans, Op. cit., P. 40.

29- Jeremy Roche, Op. cit., P. 44.

30- Marc Jans, Op. cit., PP. 35, 36.

31- Paul Stephenson, Steve Gourley, Glenn Miles, Child Participation, England: Tearfund-Roots Resources, 2004, P. 5.

ب بـ ـ اتفاقية حقوق الطفل، حق الطفل فى الاستماع إليه، لجنة حقوق الطفل، الأمم المتحدة ، الدورة

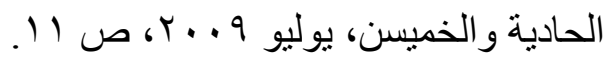

33- Gerison Lansdown, Promoting Children's Participation in Democratic Decision-Makina, Unicef: Italy, February, 2001, P. 2.

34- Ibid., P. 2.

35- Ibid., P. 9.

דبــ بيير مارك، التلميذ المهان: المدرسة مكان لا حقوق فيه، ترجمـة: فوزيـة العشماوى، المركز

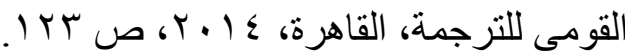

37- Gorison Lansdown, Op. cit., ., P. 9

38- Ibid., P. 10.

39- Ibid., PP. 4, 5.

40- Paul Stephenson, Steve Gourley, Glenn Miles, Op. Cit., PP. 7-8.

41- Ibid., PP. 13-15.

42- Ibid., PP. 17-19.

بـ ــ أمانى قنديل ، المجتمع المدنى فى مصر فى مطلع ألفية جديدة، مركز الدراسـات السياسية

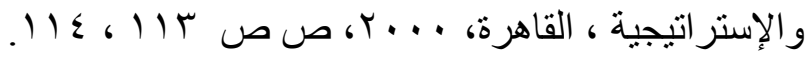

44- Gerison Lansdown, Op. cit., P. 18.

45- Ibid., PP. 21-28.

7

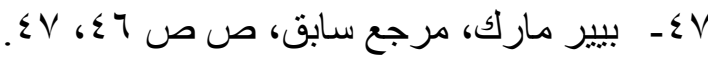

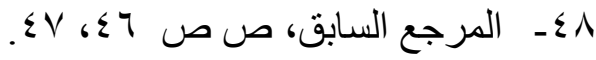

१ـــ ـ ألعاب من أجل حقوق الإنسـان، رزمـة التربيـة على حقوق الإنسـان للأطفال، مرجع سـابق، 


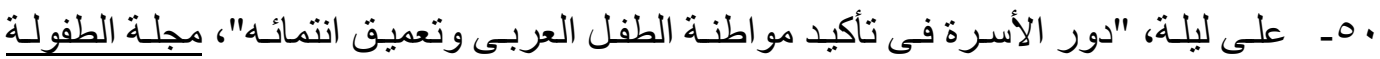

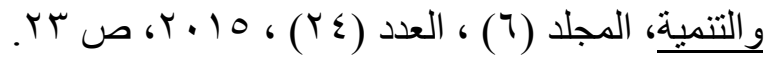

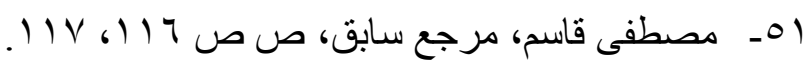

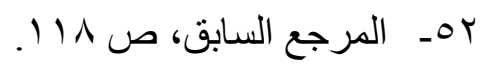

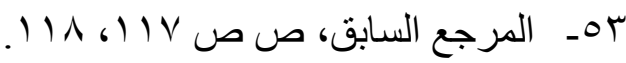

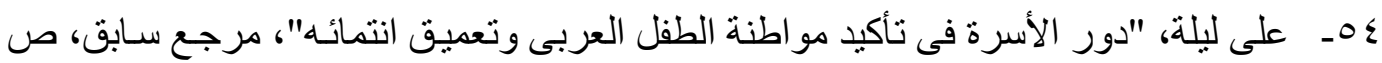
ص

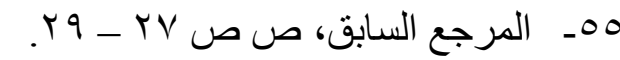

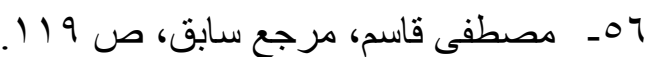

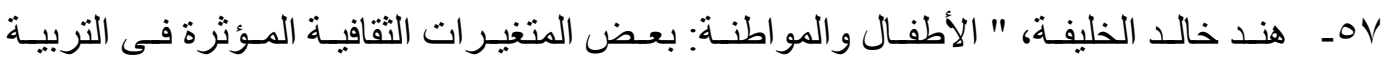

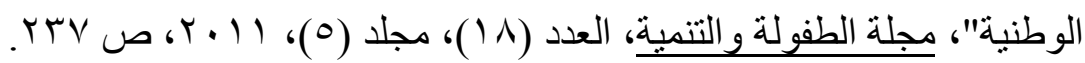

58- R. Brian Howe, et. al., Op. cit., P. 26.

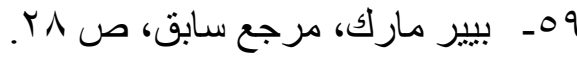

$$
\begin{aligned}
& \text { • 7- مصطفى قاسم، مرجع سابق، ص • • آ. }
\end{aligned}
$$

ال7ـ شبل بدران، التربية المدنية: التعليم و المواطنة وحقوق الإنسان، الهيئة العامـة للكتاب، القاهرة

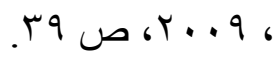

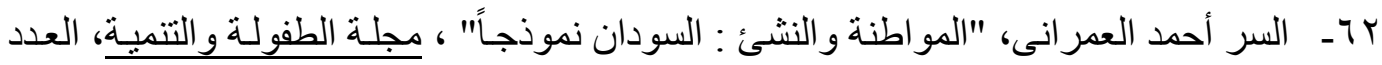

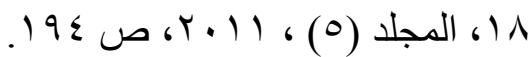

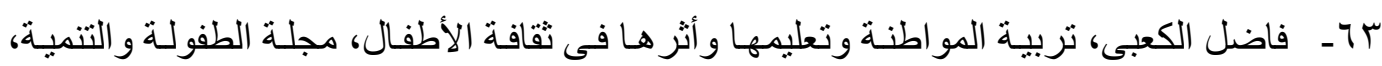

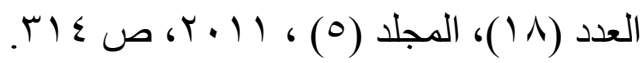

64- R. Brian Howe, et. al., op.cit., P. 26-39.

65- Ibid., P. 26.

66- Ibid., P. 27.

67- Ibid., PP. 27-28.

68- Ibid., PP. 28-29.

69- Ibid., P. 29.

70- Ibid., PP.30.

71- Ibid., PP. 30-31.

72- Ibid., P. 31.

73- Ibid., PP. 31-32.

74- Ibid., P. 32.

75- Ibid., PP. 32-33.

76- Ibid., P. 34.

77- Ibid. P. 35. 